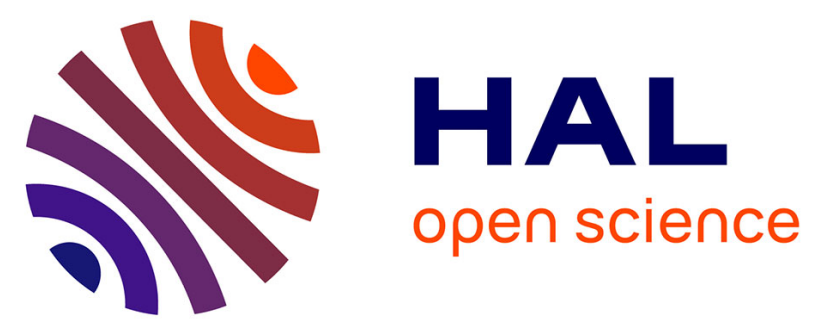

\title{
The geologic record of the exhumed root of the Central African Orogenic Belt in the central Cameroon domain (Mbé - Sassa-Mbersi region)
}

Alliance Nicaise Saha-Fouotsa, Olivier Vanderhaeghe, Pierre Barbey, Aurélien Eglinger, Rigobert Tchameni, Armin Zeh, Periclex Fosso Tchunte, Emmanuel Negue Nomo

\section{To cite this version:}

Alliance Nicaise Saha-Fouotsa, Olivier Vanderhaeghe, Pierre Barbey, Aurélien Eglinger, Rigobert Tchameni, et al.. The geologic record of the exhumed root of the Central African Orogenic Belt in the central Cameroon domain (Mbé - Sassa-Mbersi region). Journal of African Earth Sciences, 2019, 151, pp.286-314. 10.1016/j.jafrearsci.2018.12.008 . hal-02933060

\section{HAL Id: hal-02933060 https://hal.science/hal-02933060}

Submitted on 13 Oct 2021

HAL is a multi-disciplinary open access archive for the deposit and dissemination of scientific research documents, whether they are published or not. The documents may come from teaching and research institutions in France or abroad, or from public or private research centers.
L'archive ouverte pluridisciplinaire HAL, est destinée au dépôt et à la diffusion de documents scientifiques de niveau recherche, publiés ou non, émanant des établissements d'enseignement et de recherche français ou étrangers, des laboratoires publics ou privés. 
1 The geologic record of the exhumed root of the Central African Orogenic Belt in the 2 Central Cameroon Domain (Mbé - Sassa-Mbersi region)

3

4 Alliance Nicaise Saha-Fouotsa ${ }^{a}$, Olivier Vanderhaeghe ${ }^{b}$, Pierre Barbey ${ }^{c}$, Aurélien Eglinger ${ }^{d}$, 5 Rigobert Tchameni ${ }^{a}$, Armin Zeh $^{e}$, Periclex Fosso Tchunte ${ }^{a}$, Emmanuel Negue Nomo $^{f}$ 6

$7 \quad{ }^{a}$ Department of Earth Sciences, Faculty of Science, University of Ngaoundéré, P.O. Box 454, 8 Ngaoundéré, Cameroon

$9{ }^{b}$ GET, Université de Toulouse, UPS, CNRS, IRD, CNES, 14 av. E. Belin, 31400 Toulouse, 10 France

$11{ }^{c}$ Université de Lorraine, CNRS, CRPG, F-54500 Nancy, France

$12{ }^{d}$ Université de Lorraine, CNRS, GeoRessources, F-54500 Nancy, France

$13{ }^{g}$ Centre de Recherche Géologiques et Minières, BP 333, Garoua, Cameroun 14 15 16

17 Corresponding author:

18 Olivier Vanderhaeghe: olivier.vanderhaeghe@get.omp.eu 
We present structural, petrological, geochemical and geochronological data compiled in a new geological map on the high-grade metamorphic rocks exposed in the Mbé - Sassa-Mbersi region located along the Tcholliré-Banyo Shear Zone, at the northern edge of the Central Cameroon domain.

The region exposes a complex assemblage of metabasic (hornblendite, metagabbro, amphibolite) and metasedimentary (garnet paragneiss, calc-silicate gneiss) rocks alternating with ubiquitous migmatitic intermediate to felsic gneisses. U-Pb ages on detrital zircon in paragneiss point to the contribution of Archean, Paleoproterozoic and Neoproterozoic sources, and suggest a maximum deposition age of $725 \pm 12 \mathrm{Ma}$. The protolith of some amphibolites was emplaced during the Neoproterozoic as indicated by $\mathrm{U}-\mathrm{Pb}$ ages on magmatic zircon at $600 \pm 4$ and $599 \pm 6 \mathrm{Ma}$. Plutonic rocks with I-type chemical signatures were emplaced discontinuously over a period of ca. 80 Ma. The magmatic evolution started with the intrusion of magnesian medium-K tonalites and trondhjemites at $651 \pm 3 \mathrm{Ma}$, followed by magnesian high-K hornblende-biotite granites and ferroan shoshonitic biotite granites until $599 \pm 2$ Ma. Finally, pegmatite dykes were emplaced along dextral shear zones at $573 \pm 2 \mathrm{Ma}$. The metamorphic rocks show a penetrative shallow-dipping foliation partially to totally transposed in a NE-SW trending steep-dipping foliation bearing a shallow-dipping lineation. These ductile syn-migmatitic fabrics, developed under high-grade metamorphic conditions in the presence of melt, between the metamorphic peak at ca. $1.3 \mathrm{GPa}-770{ }^{\circ} \mathrm{C}$, and the following isothermal decompression down to ca. $0.8 \mathrm{GPa}$. In situ $\mathrm{U}-\mathrm{Pb}$ dating of metamorphic zircon rims yields an age of $582 \pm 4$ Ma. Localization of high-grade deformation is indicated by the development of the Tcholliré-Banyo Shear Zone, characterized by mutually crosscutting subvertical and shallow-dipping mylonitic to ultramylonitic shear zones associated with sinistral and top-to-the SW kinematic criteria, respectively. These data indicate that the Central Cameroon domain exposed in the Mbé - Sassa-Mbersi region, represents the exhumed mid- to lower part of the former orogenic root of the Pan-African Central Africa Orogenic Belt that has undergone partial melting, lateral flow and intrusion of mafic to felsic calc-alkaline magmas between 650 and $580 \mathrm{Ma}$. The waning stage of the PanAfrican orogeny is marked by the emplacement of syntectonic pegmatitic granite at ca. 575 Ma in subvertical E-W trending retrogressive dextral shear zones.

Keywords: West Gondwana; Pan-African; Central Africa Orogenic Belt; Cameroon; 
55 Highlights:

- The Central Cameroon domain is made of Pan-African metamorphic/plutonic rocks

57

- The youngest protolith of metasedimentary rocks were deposited at $<725 \mathrm{Ma}$

58

- Plutonic rocks with calc-alkaline signatures emplaced between ca. 650 and $575 \mathrm{Ma}$

59

- High-grade metamorphism $\left(1.3 \mathrm{GPa}-770^{\circ} \mathrm{C}\right)$ occurred at $>580 \mathrm{Ma}$

60

- Deformation records lateral flow of the partially molten orogenic root of the CAfOB 


\section{Introduction}

63

The Central African Orogenic Belt (CAfOB, Fig. 1), also designated as the North Equatorial Mobile Belt, or the Central African Fold Belt, is pinched between the Congo Craton, the West African Craton and the enigmatic Sahara Metacraton (Bessoles and Trompette, 1980; Nzenti et al., 1988; Abdelsalam et al., 2002; Toteu et al., 2004; Van Schmus et al., 2008). Geodynamic models proposed for the tectonic-magmatic evolution of the Central African Orogenic Belt differ in terms of the nature of the geologic domains involved and on the sources of magmatic rocks (Castaing et al., 1994; Nzenti et al., 1994, 1999; Abdelsalam et al., 2002; Ngako et al., 2003, 2008; Toteu et al., 2004; Penaye et al., 2006; Kwekam et al., 2010; Liégeois et al., 2013; Isseini et al., 2012; Nkoumbou et al., 2014; Tchakounté et al., 2017). At one end of the spectrum, some authors favour the impact of reworking of cratonic margins during the Pan-African orogeny as a result of inversion of continental to oceanic rifts followed by collision and indentation between the cratonic continental blocks (the "crustal reworking model" Fig. 2a). At the other end of the spectrum, other authors argue for a dominant magmatic accretion along an active margin (the northern margin of the Congo craton) punctuated by tectonic accretion of continental ribbons and rift basins associated with southward subduction (the "magmatic-tectonic accretion" model, Fig. 2b). These discrepancies arise essentially from contrasting interpretation of (i) the nature of the protoliths of ubiquitous migmatitic gneisses, (ii) the impact of Pan-African metamorphism and deformation relative to pre-Neoproterozoic inheritance, and (iii) the sources and petrogenetic context of widespread calc-alkaline to alkaline plutons. In the crustal reworking model, most of the magmatic activity is attributed to crustal partial melting, whereas in the magmatictectonic accretion model, at least part of the magmatic rocks with a calc-alkaline signature are assigned a mantle origin.

This debate is in particular nourished by the interpretation of the geological record of Cameroon (Toteu et al., 2004), which comprises from south to north (Fig. 1): (i) the South Cameroon domain with the Yaoundé nappe essentially made of Neoproterozoic sediments affected by partial melting under granulite facies dated at about 620-610 Ma and overthrusting the margin of the Congo craton (Nzenti et al., 1988; Barbey et al., 1990; Penaye et al., 1993; Toteu et al., 1994, 2006a; Mvondo et al., 2007; Owona et al., 2011; Nkoumbou et al., 2014); (ii) the Central Cameroon domain (also designated as the Adamawa-Yade domain) dominated by migmatitic gneisses, amphibolites, granites and some low-grade metavolcanic rocks and 
schists (Penaye et al., 1989; Toteu et al., 2001; Ganwa et al., 2011; Bouyo et al., 2013; ) and interpreted either as the northern margin of the Congo craton (Kwékam et al., 2010) or as a piece of Archaean crust detached from the Congo Craton (Tchakounté et al., 2017); and (iii) the North Cameroon domain (West Cameroon domain for some authors) comprising the PoliZalbi-Goueygoudoum greenstone belt (Bouyo et al., 2015, 2016) intruded by the Mayo-Kebbi - Sinassi calc-alkaline batholith interpreted as an early Pan-African magmatic arc active from ca. 680 to $660 \mathrm{Ma}$ (Pouclet et al., 2006; Isseini et al., 2012) and high-grade gneisses at the lowest structural level (Toteu et al., 2001). The North and Central domains are separated by the Tcholliré-Banyo Shear Zone and the Central and South domains by the Sanaga Shear Zone (Fig. 1; Toteu et al., 2001).

The presence of a Paleoproterozoic basement has been advocated in the Central African Orogenic Belt on the basis of U-Pb ages on zircon at ca. $2.0 \mathrm{Ga}$ (Toteu et al., 1987; Penaye et al., 1989) and Pan-African reworking has been first identified by widespread Neoproterozoic $\mathrm{Rb} / \mathrm{Sr}$ ages (Lasserre, 1967; Bessoles and Trompette, 1980). In addition, ages obtained on zircon and monazite grains from orthogneisses and granites (ca. 680-570 Ma) point to the intrusion of Pan-African syn- to late-tectonic plutons in the Central Cameroon domain to the north of Ngaoundéré (Toteu et al., 2001; Tchameni et al., 2006). The NE-SW trending sinistral Tcholliré-Banyo Shear Zone (TBSZ) is interpreted to represent the suture between terranes dominated by reworked Archaean to Palaeoproterozoic basement of the margin of the Congo craton and the Western Cameroon domain with a Neoproterozoic juvenile signature (Pinna et al., 1994; Toteu et al., 2001, 2004; Nomo et al., 2017).

In this paper, we complement these previous studies by the presentation of new structural, petrologic-geochemical, and geochronological data on the high-grade metamorphic and plutonic rocks exposed in the Mbé - Sassa-Mbersi region, which is situated at the northern edge of the Central Cameroon domain, along the TBSZ between the towns of Tcholliré and Banyo, about $60 \mathrm{~km}$ north of the Ngaoundéré city (Fig. 3). These data are used to discuss the pre-Neoproterozoic heritage, the impact of Pan-African reworking and the geodynamic context accounting for the reconstructed tectonic-magmatic history of this area.

\section{Geological setting and debated issues regarding the Central Cameroon domain}


129 The tectonic-metamorphic history of the Central Cameroon domain has been subdivided into 130 distinct phases based on structural analysis and geochronological data (Toteu et al., 2001; 131 Toteu et al., 2004; Ngako et al., 2008; Ngako and Njonfang, 2011). The $\mathrm{D}_{1}$ phase is 132 characterized by a shallow-dipping syn-migmatitic foliation that has been attributed to east133 verging emplacement of nappes. The $\mathrm{D}_{2}$ phase corresponds to transposition of the shallow134 dipping foliation in steep-dipping conjugate shear zones and upright folds leading to the 135 development of the main foliation with a dominant NE-SW trend recording NW-SE regional 136 shortening. The $\mathrm{D}_{1}$ and $\mathrm{D}_{2}$ phases have been dated from ca. 635 to ca. 615 Ma by applying U$137 \mathrm{~Pb}$ techniques on zircon from a variety of syntectonic plutonic rocks, and it has been proposed to group them into a single phase of crustal thickening (Ngako and Njonfang, 2011). The $\mathrm{D}_{3}$ 139 phase is related to strain localization along N-S to NE-SW sinistral shear zones, such as the 140 Banyo-Tcholliré Shear Zone and the $\mathrm{D}_{4}$ phase corresponds to retrogression associated with 141 activation of NNE-SSW to E-W trending dextral shear zones such as the Central Cameroon 142 Shear Zone. Deformation along the Tcholliré-Banyo Shear Zone was initially suggested to 143 have occurred between ca. 600 and ca. $580 \mathrm{Ma}$ based on U-Pb dating of zircon grains in syntectonic plutons (Penaye et al., 1989; Toteu et al., 2001). However, recently published U$\mathrm{Pb}$ zircon ages of syn-tectonic plutons emplaced in the Tcholliré region suggest an earlier start of deformation at $650 \mathrm{Ma}$ to ca. $630 \mathrm{Ma}$ (Nomo et al., 2017). Inherited zircon cores in these synkinematic granites, yielding late Paleoproterozoic and early Neoproterozoic ages, indicate that the plutonic rocks were formed by the reworking of older crust. The activity of the dextral NNE-SSW to E-W trending dextral shear zones crosscutting the Central Cameroon

150 domain is ill constrained but appears to predate the emplacement of post-tectonic alkaline plutons at ca. $545 \mathrm{Ma}$, which is consistent with $\mathrm{Rb} / \mathrm{Sr}$ ages at ca. $540 \mathrm{Ma}$ in this area (Bessoles and Trompette, 1980). Activation of these transcurrent shear zones has been attributed to a transpressive kinematic regime during the late-evolution of the Pan-African orogeny (Ngako et al., 2003; Ngako and Njonfang, 2011).

In the Central Cameroon domain, it was first proposed that granulite-facies mineral relicts in 157 the ortho- and para-gneisses correspond to an Eburnean metamorphism affecting the 158 Paleoproterozoic basement and that Pan-African reworking is only expressed by retrogression under amphibolite facies (Penaye et al., 1989; 2004; Ngako et al., 1990; Toteu, 2001; 2004;

160 Tchakounté et al., 2017). Alternatively, Bouyo Houketchang et al. (2009) and Bouyo et al.

161 (2013) have dated granulite facies metamorphism at ca. $600 \mathrm{Ma}$, coeval with the development 162 of a shallow-dipping foliation, and have argued that it records crustal thickening owing to 
163 Pan-African continental collision followed by retrogression into amphibolite facies during 164 exhumation.

The Central Cameroon Domain is also marked by the emplacement of magmatic rocks during the Pan-African orogeny that display a variety of petrological and geochemical signatures. Plutonic rocks consist of diorite, tonalite, trondhjemite, granodiorite and granite (Ganwa et al., 2008; Naïmou et al., 2014; Njanko et al., 2006; Tchameni et al., 2006; Toteu et al., 2001, 2004). They have been dated from ca. 640 to $570 \mathrm{Ma}$ and their calc-alkaline signatures, to high-K calc-alkaline for the youngest ones, have been attributed to mixing between a juvenile source and magmas issued from partial melting of Archean to Paleoproterozoic crust

173 (Tchameni et al., 2006; Kwékam et al., 2010; Mbassa et al., 2016; Tchakounté et al., 2017).

174 With regard to the juvenile source, two propositions have been made. Tchameni et al. (2006)

175 propose that it corresponds to an enriched mantle and Kwékam et al. (2010) invoke partial 176 melting triggered by post-collisional delamination of the subcontinental lithospheric mantle. 177 In contrast, Mbassa et al. (2016) favour partial melting of Neoproterozoic oceanic crust 178 tectonically accreted with the continental terranes.

\section{Lithological units and main structures of the Mbé - Sassa-Mbersi region}

Pioneer geological maps of the Mbé - Sassa-Mbersi region have been completed in the 50's and 60's (Koch, 1953; Guiraudie, 1955; Lasserre, 1961). These authors have proposed to distinguish, within the Precambrian rocks, (i) a basement composed of amphibole-garnet gneisses forming a NE-SW trending belt exposed along the Benue river bed across the Mbé town, and (ii) intrusive rocks represented by more or less deformed diorites, orthogneisses and granites to the East of this belt.

In this section, we present new data collected for the Mbé - Sassa-Mbersi region starting with a refined geological map for this area elaborated on the basis of more than a month of fieldwork (Fig. 3). Outcrops are dispersed but some nice exposures along the Benue riverbed near Ndong Benue and Ndom (Fig. 4), or in quarries such as in Karna, allow the characterization of the main lithological units, metamorphic facies and structural trends of the area (Figs. 5-12). Building on previous subdivisions proposed for the Mbé - Sassa-Mbersi region, we distinguish (i) metabasic rocks (amphibolites, hornblendites and metagabbros), (ii) paragneisses and calc-silicate gneiss, (iii) heterogeneous, migmatitic gneisses and 
heterogeneous granitoids with an intermediate to felsic composition, and (iv) monzodioritic to granitic plutons and dikes more or less affected by solid-state deformation (Fig. 5). Note that the previously defined "reworked Paleoproterozoic gneisses" correspond to metabasic and metasedimentary-metavolcanic rocks depicted in the new map presented in this paper, and that orthogneisses and syn- to post-tectonic granites of previous authors match the migmatitic gneisses and plutonic rocks defined in this paper. Contacts between these lithologies are typically transposed in the regional foliation (Fig. 5a to c) but intrusive contacts of the migmatitic intermediate to felsic gneisses into the amphibolites are locally preserved (Fig. 5d) and some dikes are only partially transposed (Fig. 5e).

The dominant structure is a NE-SW trending amphibolite to granulite facies foliation, which transposes the shallow-dipping foliation of metabasic rocks, paragneisses, intermediate to felsic gneisses and the intrusive contacts of plutonic rocks (Fig. 5a to e). The extreme expression of this transposition is the sinistral NE-SW trending Tcholliré-Banyo Shear Zone, delimiting the studied area to the NW. This high-temperature foliation is crosscut by dextral E-W trending mylonitic shear zones associated with retrogression into greenschist facies metamorphism (Fig. 5f).

The description of the geology of the Mbé - Sassa-Mbersi region is complemented in the next sections by petrography of the main lithological units at the outcrop scale (Figs. 6-12) and at the microscopic scale (Fig. 13).

\subsection{Metabasic rocks}

Metabasic rocks cover the most part of the studied area and are particularly well exposed along the Benue River near the villages of Ndom, Karna and Ndong Benue (Fig. 6). The metabasic rocks are characterized by a composite $S_{0 / n}$ foliation transposed in the $S_{n+1}$ schistosity. They locally display centimetre size plagioclase-rich leucosome pockets and veins containing garnet (Fig. 6a). Boudinaged metabasic rocks are ubiquitous with necks filled by plagioclase-rich veins indicating that deformation occurred in the presence of melt. The metabasic rocks correspond to a complex association of hornblendite (NB14-05, NB14-44, ML14-08; Fig. 13a), metagabbro (NB14-11b, NB14-07a and NB14-11c), amphibolite (NB14- 
mineral phase in all these rocks is amphibole, with composition encompassing the fields of

232 tschermakite, magnesio-hornblende and actinolite; $\mathrm{X}_{\mathrm{Mg}}$ values range from 0.49 to 0.81 , the 233 highest values being observed in hornblendites. Depending on samples, additional mineral 234 phases may be clinopyroxene (Wo49-50 $\operatorname{En}_{37-39} \mathrm{Fs}_{11-13}$ ), garnet (Alm54-59 $\operatorname{Prp}_{19-21} \mathrm{Grs}_{19-22} \mathrm{Sps}_{2}$ ), 235 plagioclase $\left(\mathrm{An}_{\leq 25}\right)$, biotite; minor phases are apatite, titanite and quartz; secondary phases are 236 epidote, calcite, chlorite, prehnite and sericite.

\subsection{Paragneisses and calc-silicate gneiss}

Paragneisses form a more or less continuous several kilometre-wide band trending parallel to the NE-SW Banyo-Tcholliré Shear Zone (Fig. 3). They comprise medium-grained garnet gneiss (NB14-01a, NB14-02, NB14-26ab, MM14-01) containing thin bands of fine-grained garnet gneiss (NB14-01b), felsic gneiss (N14-01c) and calc-silicate gneiss (NB14-27a, b). Lithologic alternations underline the inherited bedding transposed into a relatively shallowdipping foliation designated as $\mathrm{S}_{0 / \mathrm{n}}$. The $\mathrm{S}_{0 / \mathrm{n}}$ foliation is partially to totally transposed into a $\mathrm{S}_{\mathrm{n}+1}$ foliation in axial planar position of asymmetric folds with variably dipping axes (Fig. 7a). Transposition is associated with the development of a C/S fabric consistent with a sinistral sense of shear (Fig. 7b). The garnet gneiss is migmatitic as expressed by centimetre-thick leucosomes that are folded with the $\mathrm{S}_{0 / \mathrm{n}}$ foliation (Fig. 7c) and form a network of pockets and veins concordant-discordant to the $S_{n+1}$ foliation (Fig. 7d).

Observation under the microscope reveals that garnet gneiss, the most abundant rock type, is made up of quartz, plagioclase $\left(\mathrm{An}_{25-35}\right)$, minor K-feldspar, biotite $\left(0.50 \leq \mathrm{X}_{\mathrm{Mg}} \leq 0.69\right)$, garnet $\left(\mathrm{Alm}_{58-71} \operatorname{Prp}_{24-36} \mathrm{Sps} \leq 3_{3} \mathrm{Grs} \leq 7\right.$, with or without kyanite and sillimanite. When present, both Alsilicate phases are encountered in a same thin section, suggesting retrogression of medium- to high-pressure assemblage. Minor and accessory phases correspond mainly to muscovite, rutile, oxide and zircon. The gneiss consists of alternating quartzofeldspathic layers with a granoblastic texture and biotite \pm sillimanite layers parallel to the foliation, which is also outlined by quartz ribbons (high-temperature mylonitic texture) (Fig. 13d). Garnet contains inclusions of plagioclase, biotite, quartz and rutile, and occurs as mm- to half-cm-sized porphyroblasts commonly surrounded by a quartzofeldspathic aureole confirming the macroscopic observation. It is partly retrogressed into biotite developed in pressure shadows. Plagioclase locally occurs as half-cm size porphyroclasts. Felsic gneiss N14-01c consists 
diopside $\left(\mathrm{Wo}_{49} \mathrm{En}_{38} \mathrm{Fs}_{13} ; \mathrm{X}_{\mathrm{Mg}}=0.76 \pm 0.01\right)$, hornblende $\left(0.65<\mathrm{X}_{\mathrm{Mg}}<0.75\right)$, calcite, almost totally retrogressed plagioclase, abundant apatite, and titanite. Secondary mineral phases are chlorite $\left(\mathrm{X}_{\mathrm{Mg}}=0.62\right)$, muscovite and prehnite.

\subsection{Migmatitic intermediate to felsic gneisses}

One of the main lithological units of the Mbé - Sassa-Mbersi region consists of migmatitic gneisses and heterogeneous granitoids with a composition grading from quartz monzodiorite to leucogranite. They comprise tonalitic gneiss (MM14-05), hornblende ( \pm biotite) gneisses (N14-01b, K14-01, NB14-03b, NB14-10a, NB14-07b) and leucogneiss with or without garnet (NB14-03, CK09-1, NFA-02). The heterogeneity of these rocks is also expressed by a variety of textures and an irregular compositional layering at the centimetre to decametre scale (Fig. 8). At one hand of the spectrum, gneisses with an intermediate composition are alternating with migmatitic paragneisses (Fig. 8a) or with amphibolites that are also present as boudins (Figs. 8b, c, d). On the other hand, gneisses with a felsic composition typically display an augen texture suggesting a former magmatic fabric more or less transposed in the main foliation (Fig. 8e, f).

The migmatitic intermediate to felsic gneisses display a dominantly steeply dipping composite foliation $\mathrm{S}_{\mathrm{n}+1}$ transposing a shallow-dipping foliation $\mathrm{S}_{0 / \mathrm{n}}$. In zones of intense deformation all lithologic contacts are parallel, except for a few coarse-grained mafic boudins and pinched and swelled orthogneissic layers, indicating limited competency contrasts between mafic and felsic layers. Transposed augen gneisses grade into gneisses with feldspar porphyroclasts dispersed into a fine-grained matrix (Fig. 8f). Even in zones of intense deformation, discordant intrusive to partly transposed granitic veins are present (Fig. 8e). In contrast, in these zones, discordant mafic veins are not observed, suggesting that mafic magmatic rocks are pre-tectonic. Based on these features, in zones of penetrative solid-state deformation, it is difficult to determine whether orthogneissic layers correspond to magmatic rocks with a preNeoproterozoic protolith, to Neoproterozoic plutonic rocks or even to the leucosome part of Pan-African migmatites.

Under the microscope, a magmatic texture is still perceptible in most gneisses behind the general mylonitic fabric (Fig. 13e). Most gneiss samples consist of porphyroclasts of 
heterogeneous matrix consisting of plagioclase and variable amounts of biotite $\left(\mathrm{X}_{\mathrm{Mg}}=\sim 0.5\right)$,

300 K-feldspar and quartz. Leucogneiss typically display a high-temperature gneissic fabric outlined by quartz ribbons in a fine-grained granoblastic matrix (Fig. 13f). The matrix contains quartz, K-feldspar and plagioclase, with minor biotite $\left(0.55 \leq \mathrm{X}_{\mathrm{Mg}} \leq 0.59\right)$ or garnet $\left(\mathrm{Alm}_{57-69} \operatorname{Prp}_{24-30} \mathrm{Sps}_{\leq 3} \mathrm{Grs}_{4-15}\right)$. The composition of plagioclase ranges from $\mathrm{An}_{40}$ in hornblende ( \pm biotite) gneiss samples to $\mathrm{An}_{20-25}$ in the most silicic ones. Accessories in all these rocks consist of zircon, apatite and oxides, whereas secondary phases are chlorite, prehnite and muscovite.

\subsection{Plutonic rocks}

In the Mbé - Sassa-Mbersi area, plutonic rocks include mafic to intermediate microgranular enclaves (samples SM13-3b, SM13-1a, NB14-12, SM13-3c), tonalite and trondhjemite (L1403, NG14-02, NB14-08a), hornblende-biotite granite (CK13-6c, NB14-20, M13-1c, NB1404), biotite granite (M13-3c, L14-01, NB14-40, MM14-07) and leucogranite. Decimetre to meter-sized microgranular enclaves are common in granitic rocks, showing sub-rounded or elongated shapes. The main mineral phase assemblage of the studied samples consists essentially of plagioclase $\left(\mathrm{An}_{24-31} ; 15-30\right.$ vol.\%), amphibole (magnesio-hornblende and tschermakite; 30-47 vol.\%), biotite, K-feldspar and quartz. Accessory phases are titanite, apatite, zircon and opaque minerals. Secondary phases consist of chlorite, epidote, prehnite and calcite replacing biotite and amphiboles; and of sericite grown at the expense of feldspars.

Tonalite occurring in the northern part of the study area, corresponds to light pink, mediumgrained rocks. It consists of quartz, plagioclase $\left(\mathrm{An}_{27-29}\right)$, minor K-feldspar, biotite, amphibole (magnesio-hornblende and tschermakite); accessories are titanite, Fe-Ti oxide, zircon. Tonalite is deformed showing alternating mesocratic and leucocratic fine banding and mineral preferred orientation. Trondhjemite occurs at the Mbaou and Ndong Benue localities as veins or dykes of variable thickness. The main mineral phases are zoned plagioclase $\left(\mathrm{An}_{27-29}\right)$, quartz, and minor K-feldspar and biotite; accessory minerals are oxide and zircon. Secondary minerals are sericite and chlorite, resulting from the transformation of feldspar and biotite, respectively. Tonalite and trondhjemite show submagmatic to subsolidus deformation, with quartz-filled fractures in feldspars, mechanical twinning in plagioclase, kink-band in biotite and sub-grain development along quartz-quartz boundaries. 
333 Hornblende-biotite granites are medium- to coarse-grained $(0.2-3 \mathrm{~mm})$, equigranular to heterogranular rocks. They are compositionally heterogeneous due to mingling between mesocratic monzodioritic and leucocratic granitic facies. Hornblende-biotite granites consist of quartz (20-25 vol.\%), plagioclase $\left(\mathrm{An}_{24-29} ; 30-35 \%\right)$, more or less perthitic K-feldspar (Or $87-97$ ), biotite ( 10\%), amphibole (magnesio-hornblende and ferro-tschermakite; $\sim 10 \%$ ). Accessories consist of $\mathrm{Fe}-\mathrm{Ti}$ oxide commonly rimmed with titanite, zircon, apatite and secondary chlorite. They also individually outcrop in the Mbaou and Home localities at the East of study area (Fig. 3). Minerals are stretched according to the regional foliation including $\sigma$ and $\delta$ plagioclase porphyroclasts that are generally recrystallized in small polygonal neoblasts.

Biotite granites are the most abundant plutonic rock of the Mbé - Sassa-Mbersi area, occurring as veins or plutons mostly in the southern part of the area. They are coarse- to finegrained, greyish to pinkish rocks (Fig. 9). They consist of quartz, plagioclase $\left(\mathrm{An}_{10-30}\right), \mathrm{K}-$ feldspar and variable amount of biotite and accessory minerals (oxide, titanite, apatite, epidote and zircon). Textures range from magmatic heterogranular to mylonitic locally. A mineral preferred orientation is commonly observed, locally outlined by phenocrysts of perthitic Kfeldspar. Leucogranites occur as sheeted dykes, locally boudinaged in the foliation plane. In this case, porphyroclasts of feldspar are moulded in a fine-grained matrix, with quartz ribbons showing evidence of dynamic recrystallization.

\subsection{Mylonites and shear zones}

All lithologic units described above are affected by solid-state ductile deformation with a variable intensity. Strain gradients are expressed by transposition of lithologic contacts and by reduction of the grain size associated with mylonites and ultramylonites delineating shear zones.

The main shear zone of the studied area is the NE-SW trending Tcholliré-Banyo Shear Zone following the Benue river bed and crossing the towns and villages of Mbé, Karna and Ndom (Figs. 10 and 11). As described above, the Tcholliré-Banyo Shear Zone is associated with the presence of elongated plutonic bodies that are partly to totally transposed in accordance with the mylonitic fabric, consistent with a pre- to syn-tectonic emplacement of these plutons. In the Karna quarry, mylonites are preferentially developed to the expense of metabasic rocks 
while near Ndom, the mylonite contains numerous $\sigma$ and $\delta$ shaped feldspar porphyroclasts pointing to a granitic protolith. However, the intensity of deformation precludes the identification of the protoliths of these mylonitic rocks solely on petrological criteria. Orthogneissic layers could represent deformed equivalent of the intermediate to felsic gneisses and/or transposed plutonic rocks of the Tcholliré-Banyo batholith. The foliation of metabasites and orthogneisses, locally marked by thin leucosome concordant veins, delineates sheath folds with axes parallel to the stretching and mineral lineation. This foliation is grading into mylonite to ultramylonite associated with an extreme reduction of the grain size resulting in a dark matrix enclosing dispersed rounded porphyroclasts. The attitude of the mylonitic fabric varies at outcrop scale with NE-SW trending subvertical planes associated with a shallow-dipping lineation next to planes with a shallow-dip to the $\mathrm{N}$ also carrying a NE-SW trending lineation. The subvertical mylonitic fabric is characterized by kinematic criteria (sigma porphyroclasts and cross-cutting shear planes) consistent with a sinistral sense of shear. The shallow-dipping mylonitic fabric is associated with C' shear bands and delta porphyroclasts consistent with a top to the WSW sense of shear. The subvertical and shallowdipping mylonitic shear zones display mutual cross-cutting relationships and are expressed by similar mineral assemblages including the presence of amphibole or biotite.

The NE-SW $\mathrm{S}_{\mathrm{n}+1}$ foliation is cross-cut but by E-W trending subvertical shear zones that also offset the Tcholliré-Banyo Shear Zone (Fig. 12). The strain gradient associated with these shear zones is much sharper than the one related to the sinistral NE-SW trending shear zones. The mylonitic fabric is also marked by retrogression of amphibole and biotite in chlorite and epidote. Accordingly, these E-W trending shear zones postdate the main HT fabric of the rocks of the Mbé - Sassa-Mbersi region. It is to note that the E-W shear zones contains boudins of granitic veins but are also cross-cut by granitic dykes with a magmatic fabric or partially transposed.

These features indicate that deformation recorded by high-grade rocks of the Mbé - SassaMbersi region occurred in the presence of melt during the development of $S_{n+1}$. Melt segregation and magma migration is also expressed by emplacement of plutons into sinistral shear zones, in particular into the Tcholliré-Banyo Shear Zone, and eventually into dextral shear zones for the last granitic magmas.

\section{Major and trace element geochemistry}


402 Whole-rock major and trace elements compositions were determined in 33 samples of 403 metamorphic rocks and 15 samples of plutonic rocks at the Service d'Analyse des Roches et 404 Minéraux (SARM, CRPG-CNRS, Nancy) following the procedure described in Carignan et 405 al. (2001). Typical analytical precisions are ca. $2 \%$ for major elements and 5-8\% for trace 406 elements. Analytical data are given in Tables 1 to 4 , and sample location in the 407 Supplementary material (Table SM1).

408

\subsection{Metabasic rocks}

410

411 The metabasic rocks showing compositions ranging from gabbro to diorite (Table 1 and Fig. 412 14), are subdivided in two groups on the basis of their major elements characteristics (Fig. $41315 \mathrm{a}, \mathrm{b})$. The more magnesian group, corresponding to mafic cumulates, comprises 414 hornblendite (NB14-05, NB14-44 and ML14-08), metagabbro (NB14-07a and NB14-11c) and 415 type 1 amphibolite (NB14-11d, NB14-11b, ML14-01a and ML14-04). This group is 416 characterized by high concentrations in $\mathrm{Fe}_{2} \mathrm{O}_{3}{ }^{\text {tot }}$ (10.0-14.6 wt.\%), $\mathrm{MgO}$ (8.4-17.8 wt.\%; $\mathrm{Mg \#}$ $417=54-77)$ and $\mathrm{CaO}\left(9.6-12.8\right.$ wt.\%; $\left.\mathrm{CaO} / \mathrm{SiO}_{2}>0.24\right)$. With the exception of one sample $418\left(\right.$ ML14-01a: $\left.[\mathrm{La} / \mathrm{Yb}]_{\mathrm{N}}=47.9 ;[\mathrm{Gd} / \mathrm{Yb}]_{\mathrm{N}}=7.0\right)$, the REE patterns (Fig. 16a) are moderately 419 fractionated $\left([\mathrm{La} / \mathrm{Yb}]_{\mathrm{N}}=1.9-7.4 ;[\mathrm{Gd} / \mathrm{Yb}]_{\mathrm{N}}=1.3-2.6\right)$, with typical concave downward light 420 REE. Trace element compositions show variable but rather high concentrations in Cr (104$4211457 \mathrm{ppm}), \mathrm{Ni}$ (30-341 ppm), Sc (33-56 ppm) and V (178-366 ppm). Multi-element plot 422 shows negative anomalies in Th, U, Ta, Nb, P, Zr, Hf and Ti (Fig. 16b). Th/Yb vs. Nb/Yb plot 423 (Fig. 15d) show that some of these rocks spread along the mantle array, while others are 424 shifted towards the field of magma contaminated by crustal material.

426 The other group is made of amphibolite samples with higher and more variable $\mathrm{Fe}_{2} \mathrm{O}_{3}{ }^{\text {tot }}$ 427 contents (8.4-16.8 wt.\%) and significantly lower concentrations in $\mathrm{MgO}$ (3.5-7.7 wt.\%; $\mathrm{Mg \#}$ $428=32-49)$ and $\mathrm{CaO}\left(5.4-9.6\right.$ wt.\%; $\left.\mathrm{CaO} / \mathrm{SiO}_{2}<0.24\right)$, (Fig. 15a, b) compared to the mafic 429 cumulates. They have the composition of basalts and basaltic andesites, with silica contents 430 ranging from 45.2 to $53.9 \mathrm{wt} \%$ and $\mathrm{FeO} * / \mathrm{MgO}$ ratios indicative of a tholeiitic chemistry (Fig. 431 15c). This group comprises two types of amphibolites, designated as type 2 and type 3, 432 distinguished on the basis of their REE concentrations. Type 2 amphibolites (samples NB14433 08c, NB14-08b and NB14-10) show weakly fractionated patterns $\left([\mathrm{La} / \mathrm{Yb}]_{\mathrm{N}}=2.6-2.8\right.$; $\left.434[\mathrm{Gd} / \mathrm{Yb}]_{\mathrm{N}}=1.4-1.6\right)$ and almost no Eu anomaly $\left(\mathrm{Eu} / \mathrm{Eu}^{*}=0.9-1.1\right)($ Fig. 16c). These samples 
show lower $\mathrm{Ba}(38-280 \mathrm{ppm}), \mathrm{Rb}(6-18 \mathrm{ppm})$ and $\mathrm{Sr}(140-290 \mathrm{ppm})$ contents compared to 436 the other amphibolite samples. They have rather high $\mathrm{TiO}_{2}$ and $\mathrm{V}$ contents (1.7-2.5 wt.\%, 302-311 ppm, respectively), with Ti/V ratios (34-42) within the range of Mid Ocean Ridge

438 Basalts (MORB) (Shervais, 1982). They are also characterized by $\mathrm{Th} / \mathrm{Yb}$ and $\mathrm{Nb} / \mathrm{Yb}$ ratios close to E-MORB (Fig. 15d). Multi-element plot (Fig. 16d) shows weakly fractionated patterns, with very slight positive Ti anomaly and negative anomalies in $\mathrm{P}$ and Sr. Type 3 amphibolites (samples NB14-11a, NB14-11e, N14-01a-2 and N14-01a-1) show low Nb/La ratios (0.13-0.21) compared to other types, and strongly fractionated REE patterns (Fig. 16e), with $\left.[\mathrm{La} / \mathrm{Yb}]_{\mathrm{N}}=9.6-21.9,[\mathrm{Gd} / \mathrm{Yb}]_{\mathrm{N}}=2.6-3.4\right)$ and almost no Eu anomaly $(\mathrm{Eu} / \mathrm{Eu} *=\sim 0.9)$. Their $\mathrm{TiO}_{2}$ and $\mathrm{V}$ contents (1.3-1.7 wt.\%; 144-212 ppm, respectively) are lower than in the former type, but the $\mathrm{Ti} / \mathrm{V}$ ratios are higher (41-61). Their $\mathrm{Th} / \mathrm{Yb}$ and $\mathrm{Nb} / \mathrm{Yb}$ ratios are variable, with $\mathrm{Th} / \mathrm{Yb}$ values extending from the asthenospheric mantle array close to $\mathrm{E}$ MORB to high values laying within the field of subducted sediments (Fig. 15d). Multielement plot (Fig. 16f) shows pronounced negative anomalies in Th, U, Ta, Nb, P, Zr, Hf and Ti. These data suggest that the magmatic protolith of some type 3 amphibolites and cumulates rocks could possibly derive from partial melting of a mantle contaminated by sediments potentially recycled along a subduction zone.

\subsection{Paragneisses and calc-silicate gneiss}

Whole-rock major element composition of paragneisses (Table 2) spreads over the fields of greywackes (felsic gneiss N14-01c, garnet gneisses NB14-26ab, MM14-01, NB14-01a and NB14-02) and shales (fine-grained garnet gneiss NB14-01b) in the $\mathrm{Fe}_{2} \mathrm{O}_{3}{ }^{\text {tot }}+\mathrm{CaO}+\mathrm{TiO}_{2}$ vs. $\mathrm{Al}_{2} \mathrm{O}_{3}$ diagram (Fig. 14). Garnet gneiss and felsic gneiss samples show silica content ranging from 62.6 to 71.7 wt.\%, significant amounts of $\mathrm{CaO}$ (1.6-3.2 wt.\%), variable $\mathrm{Na}_{2} \mathrm{O}$ (1.9-4.5 wt.\%) and rather low $\mathrm{K}_{2} \mathrm{O}$ (1.5-2.2 wt.\%). Rather high $\mathrm{Zr}$ content (183-695 ppm) suggests the presence of a significant zircon component in the sedimentary protolith. Sr is variable but remains in a limited range (205-406 ppm). $\mathrm{Cr}$ and $\mathrm{Ni}$ concentrations are variable, and rather high in some samples (120-498 and 61-270 ppm, respectively). Sample N14-01c shows very high concentrations in $\mathrm{Cr}$ and $\mathrm{Ni}$ for a silicic rock; however, the fairly normal $\mathrm{Cr}$ and $\mathrm{Ni}$ contents in other rock samples and in $\mathrm{Nb}$ in this sample lead us to exclude contamination during sample preparation. A control by ore minerals cannot be excluded. Rare-earth element (REE) patterns (Fig. 17a) are moderately fractionated $\left([\mathrm{La} / \mathrm{Yb}]_{\mathrm{N}}=4.4-15.4\right)$, with weakly 
0.8). Multi-element plot normalized to primitive mantle shows negative anomalies in $\mathrm{U}$, Ta, $\mathrm{Nb}, \mathrm{Sr}, \mathrm{P}$ and Ti (Fig. 17b). These data and comparison with various average whole-rock compositions (Fig. 17a) suggest an immature siliciclastic sedimentary protolith, possibly involving reworking of mafic rocks if we consider the rather high $\mathrm{Cr}$ and $\mathrm{Ni}$ content of some samples. The fine-grained garnet gneiss sample (NB14-01b) is distinguishable by lower $\mathrm{SiO}_{2}$ ( 53 wt.\%) and higher $\mathrm{Al}_{2} \mathrm{O}_{3}$ (21.6 wt.\%), $\mathrm{CaO}$ (5.3 wt.\%), $\mathrm{Na}_{2} \mathrm{O}$ (4.5 wt.\%) and $\mathrm{K}_{2} \mathrm{O}(3.35$ wt.\%); however, in spite of a high alumina content, it does not show the typical composition of shale as shown by the high concentrations in $\mathrm{CaO}$ and $\mathrm{Na}_{2} \mathrm{O}$, as well as in $\mathrm{Sr}$ (1348 ppm) and $\mathrm{Ba}(\sim 2500 \mathrm{ppm})$. This is also supported by highly fractionated REE pattern clearly distinct from average shale (Fig. 17a), with $[\mathrm{La} / \mathrm{Yb}]_{\mathrm{N}}=23.4,[\mathrm{Gd} / \mathrm{Yb}]_{\mathrm{N}}=6.7$, low heavy REE content $\left(\mathrm{Yb}_{\mathrm{N}}=5.5\right)$ and no $\mathrm{Eu}$ anomaly $\left(\mathrm{Eu} / \mathrm{Eu}^{*}=\sim 1.0\right)$. The multi-element plot (Fig. 17b) shows negative anomalies in $\mathrm{Th}, \mathrm{U}, \mathrm{Ta}$ and $\mathrm{Nb}$. These features resemble those of intermediate igneous rocks and suggest the involvement of volcanic or plutonic material in the source of the sedimentary protolith of these gneisses.

Whole-rock major element composition of calc-silicate rocks is distinguishable by low silica content (41.3 and 46.2 wt.\%) together with high concentrations in $\mathrm{CaO}$ (16.3 and $19.8 \%$ ), $\mathrm{P}_{2} \mathrm{O}_{5}(1.3$ and $4.1 \%), \mathrm{Fe}_{2} \mathrm{O}_{3}{ }^{\text {tot }}(8.7$ and $9.3 \%)$ and $\mathrm{MgO}(7.9$ and $8.2 \%)$. Concentrations in alumina ( 8.13 and $16.07 \%$ ) and alkalis are variable (Table 2). The REE concentrations are high, with light REE reaching 1000 times chondrite in one sample, and the patterns (Fig. 17a) are fractionated $\left([\mathrm{La} / \mathrm{Yb}]_{\mathrm{N}}=22.8\right.$ and 38.2; $[\mathrm{Gd} / \mathrm{Yb}]_{\mathrm{N}}=7.2$ and 7.5), with a weak negative anomaly in $\mathrm{Eu}\left(\mathrm{Eu} / \mathrm{Eu}^{*}=0.8\right)$ for the sample with the lowest $\mathrm{Al}_{2} \mathrm{O}_{3}$ content. The multielement plot (Fig. 17b) shows negative anomalies in K, Nb, Ta, Zr, Hf and Ti. Amongst the other trace elements, one should note the high concentrations in $\mathrm{Sr}$ (895 and $1672 \mathrm{ppm}$ ), $\mathrm{Cr}$ (240 and $817 \mathrm{ppm}$ ) and Ni (153 and 483 ppm). This peculiar composition characterized by high contents of both $\mathrm{Fe}$ and $\mathrm{Mg}$, together with high $\mathrm{Ca}, \mathrm{Sr}, \mathrm{P}, \mathrm{REE}, \mathrm{Cr}$ and $\mathrm{Ni}$ led us to consider that these calc-silicate rocks are not simple mixture between siliciclastic detrital material and carbonate precipitates (dolomite, calcite or siderite), but could rather involve (hydrothermal?) alteration of mafic volcanogenic material accompanied with carbonate and phosphate precipitation.

\subsection{Migmatitic intermediate to felsic gneisses}


The heterogeneity of migmatitic intermediate to felsic gneisses presented in the petrography section is illustrated in the $\mathrm{Fe}_{2} \mathrm{O}_{3}+\mathrm{CaO}+\mathrm{TiO}_{2}-\mathrm{Al}_{2} \mathrm{O}_{3}$ diagram (Fig. 14), with compositions ranging from monzodiorite to granite (Table 3). Samples with a quartz monzodioritic composition (N14-01b, K14-01, NB14-03b and MM14-05) show silica content around 57-59 wt.\%, rather high $\mathrm{FeO}$ and $\mathrm{MgO}$ contents (5.8-8.3 and 3.0-4.6 wt.\%, respectively) and variable $\mathrm{CaO}$ content (5.6-11.5 wt.\%). They are metaluminous $(0.54 \leq \mathrm{A} / \mathrm{CNK} \leq 0.92)$, magnesian and calc-alkaline in the classification of Frost et al. (2001). Sample NB14-10a has a composition of quartz monzonite $\left(\mathrm{A} / \mathrm{CNK} \leq 1.03 ; \mathrm{SiO}_{2}=62.4\right.$ wt. $\left.\%, \mathrm{~K}_{2} \mathrm{O} / \mathrm{Na}_{2} \mathrm{O}=0.94\right)$, while sample NB14-07b is tonalitic, $\left(\mathrm{A} / \mathrm{CNK} \leq 0.96 ; \mathrm{SiO}_{2}=67.5\right.$ wt.\%, $\left.\mathrm{K}_{2} \mathrm{O} / \mathrm{Na}_{2} \mathrm{O}=0.33\right)$. The most silicic samples (NB14-03b, CK09-01 and NFA2) are slightly peraluminous $(1.01 \leq$ $\mathrm{A} / \mathrm{CNK} \leq 1.05)$, ferroan and calcic, with monzogranitic (NB14-03) or syenogranitic (CK0901 and NFA2) compositions.

The REE patterns (Fig. 17c) of the samples with a monzodioritic composition (K14-01, NB14-03b and MM14-05) show moderately fractionated REE ([La/Yb $]_{\mathrm{N}}=6.2-10.7$; $\left([\mathrm{Gd} / \mathrm{Yb}]_{\mathrm{N}}=1.5-2.1\right)$, high chondrite-normalized $\mathrm{Yb}$ content $\left(\mathrm{Yb}_{\mathrm{N}}>10\right)$ and negative Eu anomaly $\left(\mathrm{Eu} / \mathrm{Eu}^{*}=0.7-0.9\right)$. Samples N14-01b, NB14-07b and NB14-10a are distinguishable by more fractionated REE $\left([\mathrm{La} / \mathrm{Yb}]_{\mathrm{N}}=18.6-30.4\right)$ and lower $\mathrm{Yb}$ contents $\left(\mathrm{Yb}_{\mathrm{N}}=3.2-7.4\right)$, associated to high $\mathrm{Sr} / \mathrm{Y}$ ratio (45.1-93.8) compared to the other samples ( $\mathrm{Sr} / \mathrm{Y} \leq 37)$. Sample NB14-03 shows fractionated REE pattern with $[\mathrm{La} / \mathrm{Yb}]_{\mathrm{N}}=9.7,[\mathrm{Gd} / \mathrm{Yb}]_{\mathrm{N}}=1.4$ and a slight negative Eu anomaly $\left(\mathrm{Eu} / \mathrm{Eu}^{*}=0.9\right)$. The variability of the heavy $\mathrm{REE}$ content and $\mathrm{Sr} / \mathrm{Y}$ ratio suggest heterogeneity in the source of these migmatitic gneisses. The two most silicic samples show distinct REE patterns, with an important negative Eu anomaly for sample NFA2 $\left(\mathrm{Eu} / \mathrm{Eu}^{*}=0.2\right)$, and $\mathrm{a}[\mathrm{La} / \mathrm{Yb}]_{\mathrm{N}}$ ratio of 0.5 for sample CK09-01. Multi-element plot (Fig. 17d) shows systematic negative anomalies in $\mathrm{Nb}$, Ta and $\mathrm{P}$; and negative anomalies in $\mathrm{Th}, \mathrm{U}$ and $\mathrm{Ti}$ in most samples.

\subsection{Plutonic rocks}

Plutonic rock samples cover a wide range of composition from the field of monzogabbro (microgranular enclaves) to the field of syenogranite in the normative Q'-ANOR diagram (Fig. 18a and Table 4). Samples are dominantly metaluminous, high-K alkali-calcic and magnesian, with the exception of the tonalitic and trondhjemitic samples (L14-03, NG14-02 and NB14-08a), which are low-K calc-alkaline, and of the biotite granite samples (M13-3c, 
L14-01, NB14-40 and MM14-07), which are slightly ferroan and localized in the shoshonitic field (Fig. 18b-d). Overall, these samples show I-type geochemistry, consistent with the mineralogical composition characterized by the presence of amphibole and biotite as the only mafic silicate minerals. $\mathrm{Rb}$ and $\mathrm{Y}+\mathrm{Nb}$ contents (Fig. 18e) mostly overlap the field of postcollisional granites, with the exception of two tonalitic and one monzodioritic samples shifted towards the volcanic arc field. Multi-element plots (Fig. 19b, d, f, h) show systematic negative anomalies in $\mathrm{Ta}, \mathrm{Nb}, \mathrm{P}$ and $\mathrm{Ti}$.

Microgranular enclaves are of two types. Three samples (SM13-3b, SM13-1a, NB14-12) correspond to mafic enclaves with $\mathrm{SiO}_{2}$ ranging from 49.1 to $54.2 \mathrm{wt} . \%$; they also have high $\mathrm{Fe}_{2} \mathrm{O}_{3}{ }^{\text {tot }}$ (7.6-11.1 wt.\%) and $\mathrm{CaO}(5.6-8.9$ wt.\%) contents. The fourth sample (SM13-3c) shows a monzogranitic composition $\left(\mathrm{Fe}_{2} \mathrm{O}_{3}{ }^{\text {tot }}=4.3, \mathrm{MgO}=1.6, \mathrm{CaO}=3.1\right.$ wt. $\left.\%\right)$. Concentrations in $\mathrm{Ba}(1276-2520$ ppm), Sr (696-1541 ppm) and $\mathrm{Zr}$ (75-386 ppm) are high and suggest contamination by the granitic host-rock. The REE patterns (Fig. 19a) are fractionated $\left.\left([\mathrm{La} / \mathrm{Yb}]_{\mathrm{N}}=8.4-25.9, \mathrm{Gd} / \mathrm{Yb}\right]_{\mathrm{N}}=2.1-2.8\right)$, with weak but variable Eu anomalies $\left(\mathrm{Eu} / \mathrm{Eu}^{*}=0.9-1.1\right)$ and high heavy $\mathrm{REE}$ content $\left(8.5 \leq \mathrm{Yb}_{\mathrm{N}} \leq 20.4\right)$.

The quartz-monzodioritic to granitic samples show $\mathrm{SiO}_{2}$ and $\mathrm{Fe}_{2} \mathrm{O}_{3}{ }^{\text {tot }}$ contents ranging from 56.7 to $65.8 \mathrm{wt} . \%$ and 7.2 to $4.8 \mathrm{wt} . \%$ in hornblende-biotite granitoids, and from 68.8 to 72.4 and 3.5 to $1.8 \%$ in biotite granite. The tonalitic (L14-03, NG14-02) and trondhjemitic (NB1408a) samples differ by more variable $\mathrm{SiO}_{2}\left(60.7-74.1\right.$ wt.\%) and $\mathrm{Fe}_{2} \mathrm{O}_{3}{ }^{\text {tot }}$ (7.4-1.5 wt.\%) contents and lower $\mathrm{K}_{2} \mathrm{O} / \mathrm{Na}_{2} \mathrm{O}$ ratios ( $\sim 0.4$ compared to $0.57-3.3$ in other granite types). Their REE patterns (Fig. 19e) are moderately fractionated $\left([\mathrm{La} / \mathrm{Yb}]_{\mathrm{N}}=8.7-14.6, \mathrm{Gd} / \mathrm{Yb}\right]_{\mathrm{N}}=2.0-$ 2.2), with positive Eu anomaly $\left(\mathrm{Eu} / \mathrm{Eu}^{*}=1.1 / 1.6\right)$ and low $\mathrm{Yb}$ content $\left(\mathrm{Yb}_{\mathrm{N}} \leq 4.7\right)$, with the exception of the more mafic sample (L14-03) showing negative Eu anomaly and higher $\mathrm{Yb}_{\mathrm{N}}$ (11.2). Hornblende-biotite granite show moderately fractionated REE patterns $\left([\mathrm{La} / \mathrm{Yb}]_{\mathrm{N}}=\right.$ 7.0-24.9, $\left.[\mathrm{Gd} / \mathrm{Yb}]_{\mathrm{N}}=1.3-3.0\right)$, with negative $\mathrm{Eu}$ anomaly $\left(\mathrm{Eu} / \mathrm{Eu}^{*}=0.7-0.9\right)$ and $\mathrm{Yb}_{\mathrm{N}}$ content ranging from 6.7 to 19.3 (Fig. 19c). The REE patterns of the biotite granite samples (Fig. 19g) are strongly fractionated $\left([\mathrm{La} / \mathrm{Yb}]_{\mathrm{N}}=41.7-99.8, \mathrm{Gd} / \mathrm{Yb}\right]_{\mathrm{N}}=3.4-7.1$ ), with enrichment in light REE $\left(\mathrm{La}_{\mathrm{N}}=256-792\right)$, a significant negative Eu anomaly $\left(\mathrm{Eu} / \mathrm{Eu}^{*} \leq 0.5\right)$ and low $\mathrm{Yb}$ content $\left(\mathrm{Yb}_{\mathrm{N}}=5.6-8.3\right)$. Multi-element plot show a significant enrichment in large ion lithophile elements (Fig. 19h). 
Overall, major and trace element data show that the plutonic rocks sampled in the Mbé -

570 Sassa-Mbersi region correspond to three magmatic series: medium-K, high-K and

571 shoshonitic. The magnesian medium-K series corresponds to the tonalitic and trondhjemitic

572 samples characterized by fractionated REE patterns with low heavy REE concentrations,

573 suggesting a possible origin by partial melting of mafic material involving fractionation of

574 amphibole and garnet. The high-K series is represented by the hornblende-biotite granite

575 samples and some mafic to intermediate microgranular enclaves; they show fractionated REE

576 patterns but the concentration in heavy REE, around 10 times chondrite, is higher than in the

577 tonalitic series, therefore suggesting generation of parent magmas with less garnet in the

578 residue. The shoshonitic series corresponds to the biotite granites characterized by very high

579 light REE contents. Nevertheless, in the absence of isotopic data it is not possible to go farther

580 into the interpretation of the source of these rocks.

\section{5. Metamorphic petrology and $\boldsymbol{P}-\boldsymbol{T}$ conditions}

584 Pressure-temperature conditions of metamorphism have been estimated using both phase 585 equilibria modelling and conventional thermobarometry. In order to constrain these $P-T$ 586 conditions, we have selected one garnet paragneiss (NB14-01a) sampled along the Benue 587 River for which we have computed pseudosections using Perple_X 6.7.9 (Connolly, 2005) 588 and the updated 2011 version of the internally-consistent thermodynamic database of Holland 589 and Powell (2011). The studied sample corresponds to a metatexite, with leucosomes forming 590 thin bands conformable to the foliation, or occurring as leucocratic aureole around garnet 591 porphyroblasts. The migmatitic foliation $\left(\mathrm{S}_{\mathrm{n}+1}\right)$ is underlined by the biotite + sillimanite 592 association (Fig. 13d). The main mineral phases consist of quartz, plagioclase, limited amount 593 of K-feldspar, garnet, biotite, sillimanite, rutile and Fe-Ti oxide. Garnets are composed of a 594 poikiloblastic core surrounded by an almost inclusion-free rim seemingly in equilibrium with 595 sillimanite.

597 Pseudosection of Fig. 20 was calculated in the $\mathrm{TiO}_{2}-\mathrm{Na}_{2} \mathrm{O}-\mathrm{CaO}-\mathrm{K}_{2} \mathrm{O}-\mathrm{FeO}-\mathrm{MgO}-\mathrm{Al}_{2} \mathrm{O}_{3}-\mathrm{SiO}_{2}-$ $598 \mathrm{H}_{2} \mathrm{O}$ (TNCKFMASH) system. Phases involved in modelling are Biotite (Bt), K-feldspar 599 (Fsp), Garnet (Gt), Kyanite (Ky), Melt (L), Plagioclase (Pl), Quartz (Qtz), Rutile (Rt), White 600 Mica (Ms), Sillimanite (Sil), Ilmenite (Ilm) and Staurolite (St). The solution models utilized 601 for metamorphic minerals and the bulk rock composition are presented in the Supplementary 602 material (Tables SM2 and SM3, respectively). The amount of $\mathrm{H}_{2} \mathrm{O}$ in the pseudosection 
603 calculations is a critical variable that cannot be inferred solely on the basis of bulk 604 composition analyses (i.e. loss-on-ignition). The amount of water involved at high 605 temperature is determined via a series of $T-M_{\mathrm{H} 2 \mathrm{O}}$ pseudosections, such that the solidus is

606

607

608

609

610

611

612

613

614

615

616

617

618

619

620

621

622

623

624

625

626

627

628

629

630

631

632

633 634 635 636

water-saturated at $1.0 \mathrm{GPa}$. To refine the $P-T$ conditions experienced by the garnet paragneiss, the phase diagram section has been contoured for $X_{\mathrm{Mg}}, X_{\mathrm{Ca}}$ and $X_{\mathrm{Fe}}$ in garnet. The grossularite content $\left(0.12 \leq X_{\mathrm{Ca}} \leq 0.15\right)$ is the component that will be the least modified by retrograde exchange reactions (Pattison and Bégin, 1994); and when in equilibrium with biotite and melt, it is a good geobarometer. $P-T$ estimates on this migmatitic garnet paragneiss (Fig. 20) show that pressure peak $\left(\mathrm{M}_{1}\right)$ recorded by the grossularite content in garnet cores range in pressure from 1.22 to $1.36 \mathrm{GPa}$ and in temperature from 765 and $775^{\circ} \mathrm{C}$. The high temperatures given by modelling are consistent with the high $\mathrm{TiO}_{2}$ content of biotite (4.9-5.6 wt.\%; Table SM3). The metamorphic peak is followed by an adiabatic decompression down to 0.72-0.86 GPa and $760-780^{\circ} \mathrm{C}$ recorded by the grossularite-poor garnet rims $\left(0.04 \leq X_{\mathrm{Ca}} \leq 0.05\right)$.

Conventional thermometry has been applied to garnet amphibolite using the garnethornblende thermometer calibrated by Ravna (2000). Calculation applied to 10 garnethornblende pairs (sample ML14-01b; Table SM3) yield peak temperatures in the range of $720-870^{\circ} \mathrm{C}$ (average: $793 \pm 51^{\circ} \mathrm{C}$ ), with no systematic difference by applying core and rim analyses. Altough in agreement with the temperatures obtained from the Perple_X pseudosection, the large range of temperature obtained on garnet amphibolites could in fact indicate disequilibrium between phases.

\section{LA-ICP-MS zircon U-Pb data}

In order to determine the timing of the Pan-African metamorphic event and emplacement age of some of the plutonic rocks, we have separated zircon grains from garnet gneiss (NB14-02) and amphibolite (NB14-11a and NB14-11b), tonalite, hornblende-biotite granite and pegmatitic granite. The distinction of metamorphic and magmatic zircon is based on textural and geochemical characteristics including the $\mathrm{Th} / \mathrm{U}$ ratio, which has shown to be efficient in most cases (Corfu et al., 2003; Martin et al., 2008; Rubatto, 2002; Williams and Claesson, 1987; Zeh et al., 2010) despite some limitations (Harley et al., 2007; Möller et al., 2003). 6.1. Analytical techniques 
638 Rock samples were crushed, sieved and washed at Géosciences Environnement Toulouse

639 (GET) laboratory (France). The $50 \mu \mathrm{m}$ to $500 \mu \mathrm{m}$ fraction was then concentrated using heavy 640 liquids (bromoform and diiodomethane) and magnetic separation with a Frantz isodynamic 641 separator. Zircon grains were subsequently hand-picked under a binocular microscope, 642 mounted in epoxy blocks, and polished to expose their centre parts. Internal textures and 643 zoning were imaged using combined secondary electron microscopy (SEM), 644 cathodoluminescence (CL) and back-scattered electron (BSE) imaging techniques, obtained 645 with a JEOL JSM-6490 instrument coupled with a Gatan MiniCL at the Goethe - Universität 646 Frankfurt am Main (Germany). U-Pb isotopes analyses of zircon grains were carried out 647 successively by laser ablation inductively coupled plasma mass spectrometry (LA-ICP-MS), 648 using a Thermo-Finnigan ELEMENT and NEPTUNE mass spectrometer coupled to an 649 RESONETIC 193nm Excimer laser, at the Goethe - Universität Frankfurt am Main, Campus 650 Riedberg (Germany). Methods and instruments were the same as described in detail by 651 Gerdes and Zeh (2006, 2009), with modifications explained in Zeh and Gerdes (2012). LA652 ICP-MS methodology, analytical data and cathodoluminescence images of selected zircon 653 grains are given in Supplementary material (Table SM4, Table SM5 and Plate SM6, 654 respectively).

655

\subsection{Zircon $U-P b$ data}

Garnet paragneiss (sample NB14-02). Zircon grains mostly present a sub-rounded to rounded shape and range in size from 50 to $200 \mu \mathrm{m}$. SEM/CL images reveal zircon grains with complex internal structure with oscillatory zoning partially obliterated by re-crystallization.

661 Some grains show core-rim relationships, with xenocrystic magmatic cores, surrounded by 662 CL-dark metamorphic rims. Some grains with a sub-euhedral shape are devoid of inherited 663 cores and display oscillatory zoning. A total of $43 \mathrm{U}-\mathrm{Pb}$ analyses were acquired. The results 664 are shown in the Concordia diagram in Fig. 21a-b, and in the population density diagram in 665 Fig. 21c. In the population density diagram all data $>1000 \mathrm{Ma}$ represent ${ }^{207} \mathrm{~Pb} /{ }^{206} \mathrm{~Pb}$ ages, and 666 those $<1000 \mathrm{Ma}{ }^{206} \mathrm{~Pb} /{ }^{238} \mathrm{U}$ ages. The magmatic zircon grains/domains, all of them 667 characterized by oscillatory zoning and relatively high $\mathrm{Th} / \mathrm{U}$ ratios (mostly $>0.2$ ), reveal three 668 groups of dates. Four grains give Neoarchean ${ }^{207} \mathrm{~Pb} /{ }^{206} \mathrm{~Pb}$ dates between 2750 and $2500 \mathrm{Ma}$ 669 (all highly discordant), five grains give Paleoproterozoic ${ }^{207} \mathrm{~Pb} /{ }^{206} \mathrm{~Pb}$ dates between 2040 and $6701800 \mathrm{Ma}$ (one at $2040 \mathrm{Ma}$ is nearly concordant), and 34 grains give Neoproterozoic dates. The 
671 youngest of the Neoproterozoic magmatic grains yields a ${ }^{206} \mathrm{~Pb} /{ }^{238} \mathrm{U}$ date of $725 \pm 12 \mathrm{Ma}$

672 (concordance $\geq 95 \%$ ), which is tentatively interpreted as the maximum depositional age. The 673 diversity of ages obtained on inherited zircon grains is consistent with a sedimentary origin 674 for the investigated migmatitic garnet gneiss. Metamorphic zircon rims, characterized by low $675 \mathrm{Th} / \mathrm{U}$ ratios and diffuse, CL-dark zoning, yield concordant dates between ca. 640 and $565 \mathrm{Ma}$. 676 Three of these rims, characterized by variable $\mathrm{Th} / \mathrm{U}$ ratios between 0.25 and 0.01 , give a 677 Concordia date of $620 \pm 14 \mathrm{Ma}(\mathrm{MSWD}=1.8 ; \mathrm{n}=3)$, and five rims, all with very low $\mathrm{Th} / \mathrm{U}$ 678 ratios $<0.10$, a Concordia date of $582 \pm 4 \mathrm{Ma}(\mathrm{MSWD}=0.87 ; \mathrm{n}=6)$. The older age might 679 date an early metamorphic stage or, alternatively, results from the incomplete recrystallization 680 of inherited magmatic grains during the Pan-African high-grade metamorphic overprint, 681 which most likely occurred at $582 \pm 4 \mathrm{Ma}$.

682

683 Amphibolite (samples NB14-11a and NB14-11b). Zircon grains are typically sub-euhedral to 684 anhedral (zircon fragment), with size ranging from 200 to $450 \mu \mathrm{m}$ and show an oscillatory 685 zoning or sector zoning, typical for magmatic zircon. Some grains display a narrow irregular 686 metamorphic rim around the magmatic core. Th/U ratios range from 0.3 to 2.2 for sample 687 NB14-11a and from 0.8 to 2.4 for sample NB14-11b. A total of $40 \mathrm{U}-\mathrm{Pb}$ analyses were acquired. Both samples gave within error identical concordant dates of $600 \pm 4$ Ma for sample NB14-11a (MSWD=0.60; $\mathrm{n}=7$; Fig. 21d) and $599 \pm 6 \mathrm{Ma}$ for sample NB14-11b (MSWD=0.58; $\mathrm{n}=5$; Fig. 21e). These ages are interpreted to represent the time of crystallization of the mafic magmas during the Pan-African orogeny.

Tonalite (sample NG14-02). Zircon grains in the tonalite NG14-02 show euhedral to subeuhedral shapes. They are stubby or long prismatic, with length ranging from 200 to $500 \mu \mathrm{m}$. Cathodoluminescence images show an oscillatory zoning suggesting a magmatic origin. A total of 20 zircon domains were analyzed. All analyses domains reveal $\mathrm{Th} / \mathrm{U}$ ratios between 0.49 and 0.99 , which are typical of magmatic zircon. Twelve analyses yield a Concordia date of $651 \pm 3 \mathrm{Ma}(\mathrm{MSWD}=0.99 ; \mathrm{n}=12$; Fig. 21f), which is interpreted to reflect the time of crystallization of the tonalitic magma.

Hornblende-biotite granite (sample M13-01D). Zircon grains are prismatic, euhedral to subhedral, oscillatory zoned, with length ranging from 100 to $450 \mu \mathrm{m}$. A total of $39 \mathrm{U}-\mathrm{Pb}$ spot analyses were obtained on 30 grains. The analysed domains show $\mathrm{Th} / \mathrm{U}$ ratios of $0.43-$ 2.29, and gave a concordant date of $599 \pm 2$ Ma $(M S W D=2.0 ; n=20 ;$ Fig. 21g), which 
overlaps within error with an upper intercept age of $605 \pm 7$ Ma comprising all 39 analyses. Concordia age is interpreted to reflect the time of magma crystallization.

Pegmatite granite (sample NB14-09). Zircon grains are subhedral, oscillatory zoned, but their cores are locally blurred by patchy zoning. Ten $\mathrm{U}-\mathrm{Pb}$ analyses made on 5 grains show $\mathrm{Th} / \mathrm{U}$ ratios varying from 0.12 to 0.90 . They give a concordant date of $573 \pm 3 \mathrm{Ma}$ (MSWD = $0.097 ; \mathrm{n}=7$; Fig. 21h) within error identical to the upper intercept age of $572 \pm 10 \mathrm{Ma}$. This age is interpreted as the crystallization time of the pegmatite.

\section{Discussion}

\subsection{Nature and ages of the protoliths of metamorphic rocks}

All authors agree that the Central Cameroon domain is dominantly derived from Archean to Paleoproterozoic material with a limited volume of juvenile magmatic addition during the Neoproterozoic and intense reworking during the Pan-African orogeny (Ngako et al., 2003; Toteu et al., 2004; 2006a, 2006b; Kwekam et al., 2010; Ngako and Njonfang, 2011; Bouyo et al., 2013; 2015; Tchakounté et al., 2017). However, propositions differ on the nature of the protoliths that have been affected by deformation and metamorphism and on the nature and sources of the juvenile magmas. Kwekam et al. (2010) propose that the migmatitic gneisses correspond to Archean-Paleoproterozoic basement reworked (metacratonized) during the PanAfrican as a result of subcontinental lithospheric mantle zonal delamination following collision between the Sahara and Congo cratons. Corroborating this model, Tchakounté et al. (2017) have argued that this basement comprises Archean tonalites reworked during a highgrade Paleoproterozoic metamorphic event. The model of Toteu et al. (2004) introduces a nuance regarding the nature of the basement, proposing a Paleoproterozoic age but with an origin dominated by sediments initially derived from erosion of the Archean Congo Craton deformed and metamorphosed during the Eburnean orogeny.

The data of this study document the presence in the Central Cameroon domain of paragneisses and of amphibolites with Neoproterozoic protoliths ages. Indeed, U-Pb ages obtained on detrital zircon cores from garnet paragneiss (NB14-02), derived mostly from magmatic grains, point to the contribution of Archean (ca. 2.75-2.5 Ga), Paleoproterozoic (ca. 
magmatic zircon grain found in the garnet paragneiss (NB14-02) constrains deposition $<725 \pm$ 12 Ma. Overall, the metasediments sampled along the Benue River have a chemical composition indicating a dominant felsic source implying the proximity of a continental crust. Alternations of medium-grained gneiss and fine-grained gneiss are considered to correspond to inherited sedimentary compositional layering while leucosome/mesosome alternations reflect melt/crystal segregation. These metasediments might be equivalent to the ones exposed in the Poli and Lom series, respectively located north of the Banyo-Tcholliré Shear Zone (Bouyo et al., 2015) and in the southern part of the Central Cameroon Domain (Ngako et al., 2003; Toteu et al., 2006b). The metamorphic rocks include also at least some amphibolites (NB14-11a and NB14-11b) with U-Pb dates on zircon of ca. $600 \mathrm{Ma}$ that point to the emplacement of mafic magmas during the Pan-African orogeny.

The protolith of the migmatitic intermediate to felsic gneisses is more difficult to assess owing to the intensity of Pan-African deformation and metamorphism. As stated above, previous workers suggested that these gneisses represent relics of a reworked ArcheanPaleoproterozoic basement (Toteu et al., 2004; Ngako et al., 2006; Ngako and Njonfang, 2011; Tchakounté et al., 2017). Alternatively, the composition and texture of the migmatitic intermediate to felsic gneisses could be related to intense partial melting of metabasic and metasedimentary-metavolcanic rocks beyond the metatexite-diatexite transition allowing for efficient magma mobility. This proposition is consistent with the locally preserved intrusive contacts of the migmatitic intermediate to felsic gneisses into the metabasic and metasedimentary-metavolcanic rocks. Nevertheless, this does not preclude the presence of pre-Neoproterozoic rocks that could have participated in the generation of the migmatites.

\subsection{Petrogenesis of magmatic rocks}

The Mbé - Sassa-Mbersi region is characterized by a variety of Neoproterozoic plutonic rocks that have an I-type geochemistry but spread from magnesian medium-K calc-alkaline (tonalites and trondhjemites) and high-K calc-alkaline (hornblende-biotite granites), to ferroan shoshonitic (biotite granites). This geochemical trend also corresponds to a chronologic trend with U-Pb zircon ages of $651 \pm 3 \mathrm{Ma}$ (tonalite NG14-02), $599 \pm 2$ Ma (hornblende-biotite granite M13-01D), and $573 \pm 2 \mathrm{Ma}$ (pegmatite NB14-09). These emplacement ages fall in the range of previously published ages for plutonic rocks emplaced along the Tcholliré-Banyo shear zone, namely $686 \pm 17$ and $640 \pm 15$ (NW of Bangwa; Tchankam et al., 1997), $638 \pm 2$ 
Ma at Bangwa (Njiekak et al., 2008), $632 \pm 5$ Ma at Tonga (Njiosseu et al., 2005a, b; Toteu and Penaye, 2005), $642 \pm 2,628 \pm 3$ and $613 \pm 6 \mathrm{Ma}$ at Bafia (Tchakounté et al., 2017), and $576 \pm 4$ Ma at Kekem (Kwékam et al., 2013).

In the tectonic discrimination diagram of Pearce et al. (1984), plutonic rocks of the Mbé -

778 Sassa-Mbersi region spread from the volcanic arc field for tonalites-trondhjemites to the field 779 of post-collisional granites (hornblende-biotite granites and biotite granites; Fig. 18e). 780 Plutonic rocks are all marked by LILE enrichment and negative $\mathrm{Nb}, \mathrm{Ta}, \mathrm{P}$ and $\mathrm{Ti}$ anomalies 781 that tend to increase from the monzodioritic to the monzogranitic pole. The very low HREE 782 content and the marked negative $\mathrm{Nb}$-Ta anomaly of tonalites-trondjhemites of the magnesian 783 medium-K series could reflect an origin by partial melting of a subducted slab in presence of 784 variable amount of garnet. The signature of the hornblende-biotite and biotite granites is not 785 strongly discriminative but the higher concentration in heavy REE relative to the magnesian 786 medium-K series is consistent with generation of a parent magma with less or no garnet in the 787 residue (lower pressure?) that could possibly reflect contributions of an enriched mantle 788 source and/or of partial melting of the root of the overlying Pan-African orogenic belt. Input 789 of mafic magmas derived from partial melting of an enriched mantle synchronous with the 790 Pan-African tectono-metamorphic event is further constrained by two dated samples of type 1 791 (cumulate) and type 3 (calc-alkaline) amphibolites, with emplacement ages of $600 \pm 4$ Ma 792 (sample NB14-11a) and $599 \pm 6 \mathrm{Ma}$ (sample NB14-11b). It should be noted that it is not 793 possible to ascertain whether type 2 amphibolites, showing distinct chemistry close to E794 MORB, are Pan-African or older owing to the absence of geochronological information for 795 these rocks.

\section{6}

These results complement the study of the plutonic rocks near Ngaoundéré, just south of the 798 studied area documenting high-K, hornblende-biotite and biotite \pm muscovite granites, 799 emplaced at ca. $615 \pm 27 \mathrm{Ma}$ and ca. $575 \mathrm{Ma}$, respectively (Tchameni et al., 2006). The 800 geochemical signatures of the hornblende-biotite granites, notably the LILE enrichment and 801 the negative $\mathrm{Nb}$-Ta anomalies, have been taken as an evidence for an origin of these magmas 802 by partial melting of an enriched mantle source followed by crustal contamination and 803 fractional crystallisation. In contrast, based on their high Th content, enrichment in LREE and 804 the presence of inherited monazite, biotite granites have been interpreted to reflect partial 805 melting of the Pan-African orogenic crust (Tchameni et al., 2006). Similar signatures have 806 been obtained for plutonic rocks of the Fomopea magmatic complex straddling the Banyo- 
807 Tcholliré Shear Zone to the southwest of the studied area (Kwekam et al., 2010). U-Pb dates

808 on zircon from a diorite and a quartz-monzodiorite give Pan-African ages of $620 \pm 3$ Ma and

$809613 \pm 2 \mathrm{Ma}$, respectively. In addition, to major and trace elements, $\mathrm{Sr}-\mathrm{Nd}$ isotopic data

810 indicate mixing between a juvenile source and a Palaeoproterozoic to Archaean lower

811 continental crust. These data are interpreted by Kwékam et al. (2010) to reflect partial melting

812 of the mantle following delamination of the subcontinental lithospheric mantle beneath the

813 Western and Central Cameroon Domain and inducing widespread partial melting of the

814 Archaean-Paleoproterozoic basement. To the north of the Fomopea complex, the Mbengwi

815 magmatic complex, intruding the North Cameroon Domain also displays similar petrological

816 and geochemical characteristics (Mbassa et al., 2016). However, based on the low Mg\#,

817 LREE enrichment, and negative Eu anomaly, the high-K calc-alkaline magmas have been

818 attributed by Mbassa et al. (2016) to partial melting of crustal sources including contributions

819 of Neoproterozoic juvenile oceanic crust tectonically accreted during the Pan-African in the

820 Central African Orogenic Belt with reworked Archaean to Paleoproterozoic crust.

822 The Neoproterozoic mafic magmas identified in the Mbé - Sassa-Mbersi region correspond to metabasic rocks with a cumulate character and to type 1 and 3 amphibolites. These metabasic rocks display differentiated REE patterns enriched in LREE and LILE with $\mathrm{Nb}$, Ta, $\mathrm{P}$, and Ti negative anomalies similar to the plutonic rocks but also to the metasedimentary rocks and the migmatitic intermediate to felsic gneisses. Accordingly, the geochemical signature of the migmatitic intermediate to felsic gneisses and of the plutonic rocks of the Central Cameroon Domain might reflect the characteristics of crustal rocks (arc crust, metasediments and/or continental basement) tectonically accreted to the Central African Orogenic Belt during the Pan-African rather than the composition of the underlying mantle. In this case, the only definite evidence for an enriched mantle underlying the Central African Orogenic Belt comes from the trace element signatures of the cumulate metabasic rocks and of the type 1 and 3 amphibolites. Following this reasoning, the E-MORB composition of the type 2 amphibolites might reflect either partial melting of a different part of the mantle during the Neoproterozoic or partial melting of the mantle during a preceding event of juvenile accretion (presumably the Paleoproterozoic). To choose between these propositions will require additional geochronological and isotopic tracing of these rocks. 
841 Models proposed for the evolution of the Pan-African Central African Orogenic Belt invoked 842 a polyphased tectonic record on the basis of relative chronology established by structural 843 geology and absolute dating of plutonic rocks positioned relative to structures (Penaye et al., 844 1989; Toteu et al., 2001, 2004). Following this strategy, Toteu et al. (2004) identified a first 845 phase $\mathrm{D}_{1}$ of nappe emplacement followed by a second phase $\mathrm{D}_{2}$ of $\mathrm{E}-\mathrm{W}$ shortening associated 846 with transposition of the shallow-dipping foliation into a subvertical one. $\mathrm{As} \mathrm{U}-\mathrm{Pb}$ ages are 847 not different for these tectonic phases and range from ca. $635 \mathrm{Ma}$ to ca. $615 \mathrm{Ma}$, Ngako and 848 Njonfang (2011) grouped them into a single prolonged crustal thickening phase. A similar 849 reasoning could be applied to the $\mathrm{D}_{3}$ phase. Indeed, for example, the activity of the Banyo850 Tcholliré Shear Zone was first considered to be limited to the time period between ca. 600 and 851 ca. 580 Ma (Penaye et al., 1989; Toteu et al., 2001), but new U-Pb ages obtained on 852 magmatic zircons from syn- to late-tectonic plutons emplaced in the Tcholliré region imply 853 that it was already active from ca. $650 \mathrm{Ma}$ to ca. $630 \mathrm{Ma}$ (Nomo et al., 2017). The age of 651 $854 \pm 3$ Ma obtained on tonalite (NG14-02), the oldest plutonic rock identified in the Mbé 855 Sassa-Mbersi area, further strengthen this proposition. The structural analysis presented in this 856 paper is consistent with coeval development of the shallow-dipping $\mathrm{S}_{0 / n}$ foliation and of the 857 steep-dipping $\mathrm{S}_{\mathrm{n}+1}$ schistosity in the presence of melt. The general NE-SW trend of the 858 Tcholliré-Banyo Shear Zone, parallel to the azimuth of the regional $S_{n+1}$ foliation suggests 859 localization of this deformation phase. This proposition is consistent with the one of Ngako 860 and Njonfang (2011) to consider that the shallow-dipping and steeply dipping foliations are 861 both recording a period of crustal thickening. However, we nuance this model and advocate 862 that coeval subvertical and shallow-dipping shear zones associated with a shallow-dipping 863 mineral and stretching lineation suggest a finite strain ellipsoid in the constriction field with 864 partitioning of the strike slip component along subvertical shear zones (Chardon et al., 2009; 865 Fossen and Tikoff, 1998; Tikoff and Teyssier, 1994).

867 Thermodynamic modelling shows that the peak metamorphic conditions recorded in the 868 garnet cores of metasediments ( $\mathrm{M}_{1}$; ca. $1.3 \mathrm{GPa}$ for ca. $770{ }^{\circ} \mathrm{C}$ ) was followed by an 869 isothermal decompression down to ca. $0.8 \mathrm{GPa}\left(\mathrm{M}_{2}\right.$ retrograde event recorded in the garnet 870 rims). These conditions are consistent with those reported by previous investigations that 871 yielded peak pressures at 1.3-1.4 GPa from conventional geothermobarometry (Bouyo et al., 872 2013). Following the criteria of the continuity of the syn-migmatitic foliation (Brown, 1973; 873 Vanderhaeghe, 2001, 2009), these migmatitic paragneisses classify as metatexites and 874 represent former partially molten rocks. Garnet porphyroblasts are typically surrounded by a 
quartzofeldspathic halo or are included in larger centimetre to decimetre size leucosome veins suggesting that garnet is a peritectic phase formed from biotite-dehydration melting in agreement with temperature estimates. These features indicate that partial melting and melt segregation occurred during deformation associated with the development of $\mathrm{S}_{\mathrm{n}+1}$. However, pristine magmatic textures are seldom preserved in leucosomes that are in most places affected by a solid-state fabric and even pinched and swelled into the $\mathrm{S}_{\mathrm{n}+1}$ foliation. The youngest concordant zircon grains (rims with $\mathrm{Th} / \mathrm{U}$ ratios $<0.12$ ) from the garnet paragneiss (NB14-02) yields an average concordant date of $582 \pm 4$ Ma providing a minimum age for this high-grade metamorphism. These ages are consistent with previous zircon $\mathrm{U}-\mathrm{Pb}$ data indicating 600-580 Ma for the timing of anatexis and deformation, and with Sm-Nd data on whole-rock-garnet pair from metapelite which gave an age of $600 \pm 5 \mathrm{Ma}$ (Toteu et al., 1987, 2001; Bouyo Houketchang et al., 2009; Bouyo et al., 2015). Nevertheless, it should be noted that zircon tends to crystallize with the melt phase during the retrograde path (Kelsey et al., 2008; Yakimchuk et al., 2014), which implies that these ages probably provide a minimum for the onset of melting. Such a protracted duration for high-temperature metamorphism and deformation in the presence of melt for several tens of Ma has been proposed for other orogenic belts (Vanderhaeghe et al., 1999; Harley, 2016; Guergouz et al., 2018; Turlin et al., 2018).

In order to account for the structural, petrologic, metamorphic and geochronologic data presented in this paper integrated with previously published data we propose that the Central Cameroon Domain has recorded lateral flow of a partially molten orogenic root in a similar way to what has been proposed for the Cenozoic Tibetan and the Proterozoic Grenville orogenic plateaus (Royden et al., 1997; Hodges, 2000; Vanderhaeghe and Teyssier, 2001; Vanderhaeghe, 2012; Turlin et al., 2018) or was described for the Archean Dharwar craton (Chardon and Jayananda, 2008) and for the Paleoproterozoic Finnish Svecofennides (Cagnard et al., 2007). This lateral flow is consistent with coeval vertical and shallow-dipping shear zone associated with a dominant shallow-dipping stretching direction. U-Pb dating of syntectonic plutons is consistent with an onset of this lateral flow around ca. $650 \mathrm{Ma}$ and ongoing until $580 \mathrm{Ma}$ in the presence of melt. Lateral flow of the orogenic crust is also coeval with the input of mantle-derived magmas as evidenced by the metabasites with emplacement ages of ca. $600 \mathrm{Ma}$. Retrogression associated with activation of NNE-SSW to E-W trending dextral shear zones such as the Central Cameroon Shear Zone marks the waning stage of the Pan- 
$909 \mathrm{~Pb}$ age of $573 \pm 3 \mathrm{Ma}$ obtained on magmatic zircon from a partially transposed pegmatitic 910 granite in a dextral shear zone probably represents the last plutonic event of the waning stage 911 of the Pan-African orogeny.

\section{Summary and conclusion}

916 The Mbé - Sassa-Mbersi area exposes a complex assemblage of metabasic rocks 917 (amphibolites, hornblendites, metagabbros), paragneisses with calc-silicate layers grading into 918 ubiquitous migmatitic intermediate to felsic gneisses. Paragneisses contain detrital zircon 919 pointing to the contribution of Archean, Paleoproterozoic and Neoproterozoic sources. The 920 youngest age obtained on a detrital core of $725 \pm 12$ Ma provides a maximum age for the 921 deposition of the protolith of these paragneisses. At least some of the protoliths of the 922 metabasic rocks have been emplaced during the Neoproterozoic as indicated by $\mathrm{U}-\mathrm{Pb}$ ages on 923 magmatic zircon from amphibolites at $600 \pm 4$ and $599 \pm 6$ Ma.

These metamorphic rocks display a penetrative shallow-dipping syn-migmatitic foliation partially to totally transposed in a NE-SW trending steep-dipping foliation also delineated by 927 leucosomes and associated with sinistral kinematic indicators. These fabrics bear a shallow928 dipping mineral lineation that records a dominant NE-SW stretching direction. The 929 development of this ductile fabric occurred under granulite to amphibolite facies metamorphic 930 conditions as constrained by a peak at ca. $1.3 \mathrm{GPa}$ and ca. $770{ }^{\circ} \mathrm{C}$, followed by isothermal decompression down to ca. $0.8 \mathrm{GPa}$ obtained by thermodynamic modelling on a migmatitic garnet paragneiss. The same garnet paragneiss contains zircon with $\mathrm{U}-\mathrm{Pb}$ ages spreading along Concordia from ca. $640 \mathrm{Ma}$ to ca. $565 \mathrm{Ma}$ and yielding a well-constrained minimum

934 age for metamorphic rims at $582 \pm 4 \mathrm{Ma}$. Localization of high-grade deformation is marked 935 by the development of the Tcholliré-Banyo Shear Zone characterized by mutually cross936 cutting subvertical and shallow-dipping mylonitic to ultramylonitic shear zones associated 937 with sinistral and top-to-the SW kinematic criteria respectively. The high-grade fabric is cross-cut by lower-grade localized E-W trending subvertical dextral shear zones.

940 Intrusive, partially transposed plutonic rocks display a composition spanning from 941 monzodiorite to granite, showing I-type chemical signature. All these plutonic rocks show a 942 differentiated REE pattern associated with enrichment in LREE and LILE and negative 
anomalies in $\mathrm{Nb}$, Ta, $\mathrm{P}$ and Ti. Nevertheless, three main series are distinguished; (i) tonalites-

944 trondhjemites with a magnesian medium-K signature, (ii) hornblende-biotite granites with a magnesian high-K signature and biotite-granite with a ferroan shoshonitic signature; that might reflect a variety of sources and/or of the conditions of partial melting, but discussing more thoroughly this point will require some additional isotopic data. The emplacement of these different magmatic rocks occurred over a period of more than $80 \mathrm{Ma}$ as constrained by zircon U-Pb data at $651 \pm 3 \mathrm{Ma}$ (medium-K tonalite), $599 \pm 2 \mathrm{Ma}$ (high-K hornblende-biotite granite), and $573 \pm 2 \mathrm{Ma}$ (pegmatite dyke partially transposed in dextral shear zone).

Based on these data, we propose that the Central Cameroon Domain exposed in the Mbé Sassa-Mbersi region represents the exhumed mid- to lower part of the former orogenic root of the Pan-African Central African Orogenic Belt. This root has undergone protracted synmigmatitic deformation, horizontal stretching, sinistral shearing and emplacement of mafic to felsic calc-alkaline magmas from 650 to $580 \mathrm{Ma}$ associated with exhumation. The waning stage of the Pan-African orogeny is marked in this region by the emplacement of syn-tectonic pegmatitic granite at ca. $575 \mathrm{Ma}$ partially transposed in subvertical E-W trending retrogressive dextral shear zones.

\section{Acknowledgements.}

962 This work is part of the first author's $\mathrm{PhD}$ integrated in the URCO research project financially 963 supported by the CNRS-NEEDS program and the AUF program (Project $\mathrm{N}^{\circ}$ 51110SU201).

964 We acknowledge fruitful discussions with Moussa Isseini, Julien Berger and Anne-Sylvie 965 André-Mayer (despite the absence of mineralization!). Alexandre Flammang at 966 GeoRessources, Fabienne De Parseval, Jean-François Ména and Ludovic Menjot at GET are 967 thanked for the very nice thin sections, Jérôme Marin and the SARM team at the CRPG 968 Nancy for very efficient major and trace elements analyses, Philippe de Parseval and Sophie

969 Gouy for their kind and rigorous assistance using the electronic microprobe of the Centre 970 Raymond Castaing in Toulouse.

\section{References}

973 Abdelsalam, M.G., Liégeois, J.P., Stern, R.J., 2002. The Saharan Metacraton. J. Afr. Earth 974 Sci. 34, 119-136.

975 Barbey, P., Macaudière, J., Nzenti, J.P., 1990. High-pressure dehydration melting of 976 metapelites. Evidence from the Yaoundé migmatites. J. Petrol. 31, 401-427. 
Bessoles, B., Trompette, R., 1980. La chaîne pan-africaine «zone mobile d'Afrique centrale (partie sud) et zone mobile soudanaise ». Mém. B.R.G.M. 92, 326 p.

Bouyo, M.H., Penaye, J., Njel, U.O., Moussango, A.P.I., Sep, J.P.N., Nyama, B.A., Wassouo, W.J., Abate, J.M.E., Yaya, F., Mahamat, A., Ye, H., Wu, F., 2016. Geochronological, geochemical and mineralogical constraints of emplacement depth of TTG suite from the Sinassi Batholith in the Central African Fold Belt (CAFB) of northern Cameroon: Implications for tectonomagmatic evolution. J. Afr. Earth Sci. 116, 9-41.

Bouyo, M.H., Zhao, Y., Penaye, J., Zhang, S.H., Njel, U.O., 2015. Neoproterozoic subduction-related metavolcanic and metasedimentary rocks from the Rey Bouba Greenstone Belt of north-central Cameroon in the Central African Fold Belt: New insights into a continental arc geodynamic setting. Precambrian Res. 21, 40-53.

Bouyo Houketchang, M., Toteu, S.F., Deloule, E., Penaye, J., Van Schmus, W.R., 2009. U-Pb and Sm-Nd dating of high-pressure granulites from Tcholliré and Banyo regions: Evidence for a Pan-African granulite facies metamorphism in north-central Cameroon. J. Afr. Earth Sci. 54, 144-154.

Bouyo, M.H., Penaye, J., Barbey, P., Toteu, S.F., Wandji, P., 2013. Petrology of highpressure granulite facies metapelites and metabasites from Tcholliré and Banyo regions: geodynamic implication for the Central African Fold Belt (CAFB) of north-central Cameroon. Precambrian Res. 224, 412-433.

Brown, M., 1973. The definition of metatexis, diatexis and migmatite. Proceedings of the Geological Association 84, 371-382.

Cagnard, F., Gapais, D., Barbey, P. 2007. Collision tectonics involving juvenile crust: The example of the southern Finnish Svecofennides. Precambrian Research 154, 125-141.

Carignan, J., Hild, P., Mévelle, G., Morel, J., Yeghicheyan, D., 2001. Routine analyses of trace elements in geological samples using flow injection and low pressure on-line liquid chromatography coupled to ICP-MS: a study of reference materials BR, DR-N, UB-N, AN-G and GH. Geostandards Newsletter 25, 187-198.

Castaing, C., Feybesse, J.L., Thiéblemont, D., Triboulet, C., Chévremont, P., 1994. Paleogeographical reconstructions of the Pan-African/Brasiliano orogen: closure of an oceanic domain or intracontinental convergence between major blocks? Precambrian Res. $69,327-344$.

Chardon, D., Jayananda, M. 2008. Three-dimensional field perspective on deformation, flow, and growth of the lower continental crust (Dharwar craton, India). Tectonics, 27, doi:10.1029/2007TC002120 
1011 Chardon, D., Gapais, D., and Cagnard, F. 2009. Flow of ultra-hot orogens: A view from the 1012 Precambrian, clues for the Phanerozoic. Tectonophysics 477, 105-118

1013 Connolly, J.A.D., 2005. Computation of phase equilibria by linear programming: A tool for 1014 geodynamic modelling and its application to subduction zone decarbonation. Earth Planet. 1015 Sci. Letters 236, 524-541.

1016 Corfu, F., Hanchar, J.M., Hoskin, P.W.O., Kinny, P.D., 2003. Atlas of zircon textures. 1017 Reviews in Mineralogy and Geochemistry 53, 469- 500.

1018 Evensen, N.M., Hamilton, M.J., O'Nions, R.J., 1978. Rare-earth abundances in chondritic 1019 meteorites. Geochim. Cosmochim. Acta 42, 1199-1212.

1020 Fossen, H., and Tikoff, B., 1998. Extended models of transpression and transtension, and 1021 application to tectonic settings. In: Holdsworth, R. E., Strachan, R. A. \& Dewey, J. E (eds) 1022 1998. Continental Transpressional and Transtensional Tectonics. Geological Society, 1023 London, Special Publications, 135, 15-33.

1024 Frost, B.R., Barnes, C.G., Collins, W.J., Arculus, R.J., Ellis, D.J., Frost, C.D., 2001. A 1025 geochemical classification for granitic rocks. J. Petrol. 42(11), 2033-2048.

1026 Ganwa, A.A., Frisch, W., Siebel, W., Ekodeck, G.E., Shang, C.K., Ngako, V., 2008. Archean 1027 inheritances in the pyroxene-amphibole-bearing gneiss of the Méiganga area (Central 1028 North Cameroon): Geochemical and ${ }^{207} \mathrm{~Pb} /{ }^{206} \mathrm{~Pb}$ age imprints. C.R. Geoscience 340, 2111029

1030 Ganwa, A.A., Siebel, W., Shang Kongnyuy, C., Seguem, Naimou, Ekodeck, G.E., 2011. New 1031 constraints from Pb-Evaporation zircon ages of the M_eiganga amphibole biotite gneiss, 1032 Central Cameroon, on Proterozoic crustal evolution. Int. J. Geosci. 2, 138-147.

1033 Gerdes, A., Zeh, A., 2006. Combined U-Pb and Hf isotope LA-(MC-)ICP-MS analyses of 1034 detrital zircons: Comparison with SHRIMP and new constraints for the provenance and 1035 age of an Armorican metasediment in Central Germany. Earth Planet. Sc. Lett. 249, 47-61. 1036 Gerdes, A., Zeh, A., 2009. Zircon formation versus zircon alteration - new insights from 1037 combined $\mathrm{U}-\mathrm{Pb}$ and Lu-Hf in-situ LA-ICP-MS analyses, and consequences for the 1038 interpretation of Archean zircon from the Limpopo Belt. Chem. Geol. 261, 230-243.

1039 Gromet, L.P., Haskin, L.A., Korotev, R.L., Dymek, R.F., 1984. The "North American shale 1040 composite": its compilation, major and trace element characteristics. Geochim. 1041 Cosmochim. Acta 48, 2469-2482.

1042 Guergouz C., Martin L., Vanderhaeghe O., Thébaud N., Fiorentini M. (2018). Zircon and 1043 monazite textural and $\mathrm{U}-\mathrm{Pb}$ record of prolonged amphibolite to granulite facies 1044 metamorphism in the Ivrea and Strona-Ceneri Zones, NW Italy. Lithos 308-309, 1-18 
1045 Guiraudie, C., 1955. Notice explicative sur la feuille Ngaoundéré-Ouest. Carte géologique de reconnaissance à l'échelle 1/500 000. Territoire du Cameroun, 1 carte, Paris, Vol. 1, nº $500,23 p$.

1048

Harley, S., 2016. A matter of time: the importance of the duration of UHT metamorphism. Journal of Mineralogical and Petrological Sciences 111, 50-72.

Harley, S.L., Kelly, N.M., Möller, A., 2007. Zircon behaviour and the thermal histories of mountain chains. Elements 3: 25-30

Hodges, K. 2000. Tectonics of the Himalaya and southern Tibet from two perspectives. Geological Society of America Bulletin. 112, 324-350.

Holland, T.J.B., Powell, R., 2011. An improved and extended internally consistent thermodynamic dataset for phases of petrological interest, involving a new equation of state for solids. Journal of Metamorphic Geology 29(3), 333-383.

Isseini, M., André-Mayer, A.S., Vanderhaeghe, O., Barbey, P., Deloule, E., 2012. A-type granites from the Pan-African orogenic belt in south-western Chad constrained using geochemistry, Sr-Nd isotopes and U-Pb geochronology. Lithos 153, 39-52.

Kelsey, D.E., Clark, C., Hand, M., 2008. Thermobarometric modelling of zircon and monazite growth in melt-bearing systems: examples using model metapelitic and metapsammitic granulites. Journal of Metamorphic Geology 26, 199-212.

Koch, P., 1953. Carte géologique du Cameroun au 1/500 000. Coupure Banyo, avec notice explicative. Imprimerie nationale.

Kwékam, M., Affaton, P., Bruguier, O., Liégeois, J.P., Hartmann, G., Njonfang, E., 2013. The Pan-African Kekem gabbro-norite (West-Cameroon), U-Pb zircon age, geochemistry and Sr-Nd isotopes: Geodynamical implication for the evolution of the Central African fold belt. Journal of African Earth Sciences 84, 70-88.

Kwékam, M., Liégeois, J.P., Njonfang, E., Affaton, P., Hartmann, G., Tchoua, F., 2010). Nature, origin and significance of the Fomopéa Pan-African high-K calc-alkaline plutonic complex in the Central African fold belt (Cameroon). Journal of African Earth Sciences 57(1), 79-95.

Küster, D. \& Liégeois, J.P. (2001). Sr, Nd isotopes and geochemistry of the Bayuda Desert high-grade metamorphic basement (Sudan): an early Pan-African oceanic convergent margin, not the edge of the East Saharan ghost craton? Precambrian Res., 109, 1-23.

Lasserre, M., 1961. Etude géologique de la partie orientale de l'Adamaoua (Cameroun Central) et les principales sources minéralisées de l'Adamaoua. Bulletin de la Direction des Mines et Géologie du Cameroun. 
1079 La Roche, H. de, 1965. Sur l'existence de plusieurs faciès géochimiques dans les schistes 1080 paléozoïques des Pyrénées luchonnaises. Geol. Rundsch. 55, 274-301.

1081 Lasserre, M., 1967. Données géochronologiques nouvelles acquises au 1er janvier 1967 par la 1082 méthode au Strontium appliquée aux formations cristallines et cristallophylliennes du 1083 Cameroun. Ann. Fac. Sci. Univ. Clermont-Ferrand 36(16), 109-144.

1084 Liégeois, J.P., Abdelsalam, M.G., Ennih, N., Ouabadi, A., 2013. Metacraton: Nature, genesis 1085 and behavior. Gondwana Res. 23, 220-237.

1086 Martin L., Duchêne S., Deloule E., Vanderhaeghe O. 2008. Mobility of trace elements and 1087 oxygen isotopes during metamorphism: consequences on geochemical tracing. Earth and Planetary Science Letters, 267, 161-174.

Mbassa, B.J., Kamgang, P., Grégoire, M., Njonfang, E., Benoit, M., Itiga, Z. \& Nfomou, N., 2016. Evidence of heterogeneous crustal origin for the Pan-African Mbengwi granitoids and the associated mafic intrusions (northwestern Cameroon, central Africa). Comptes Rendus Geoscience 348(2), 116-126.

Miyashiro, A., 1974. Volcanic rock series in island arcs and active continental margins. Amer. J. Sci. 274, 745-750.

Möller A, O’Brien PJ, Kennedy A, Kröner A. 2003. Linking growth episodes of zircon and metamorphic textures to zircon chemistry: an example from the ultrahightemperature granulites of Rogaland (SW Norway). In: Vance D, Müller W, Villa IM (eds) Geochronology: Linking the Isotopic Record with Petrology and Textures. Geological Society of London Special Publication 220, 65-81.

Mvondo, H., Owona, S., Mvondo Ondoa, J., Essono, J., 2007. Tectonic evolution of the Yaounde segment of the Neoproterozoic Central African Orogenic Belt in the southern

1103 Naïmou S., Ganwa A. A., Urs K., Amadou D. K., Ekodeck G. E., 2014. Petrography and 1104 Geochemistry of Precambrian Basement Straddling the Cameroon-Chad Border: The 1105 Touboro-Baïbokoum Area. International Journal of Geosciences 5, 418-431.

1106 Ngako, V., Affaton, P., Njongfang, E., 2008. Pan-African tectonics in northwestern 1107 Cameroon: Implication for the history of western Gondwana. Gondwana Res. 14, 509-522. 1108 Ngako, V., Affaton, P., Nnange, J.M., Njanko, T., 2003. Pan-African tectonic evolution in 1109 central and southern Cameroon: transpression and transtension during sinistral shear 1110 movements. J. Afr. Earth Sci. 36(3), 207-214. 
1111 Ngako, V., Jégouzo, P., Soba, D., 1990. Déformation et métamorphisme dans la chaîne Pan1112 Africaine de Poli (Nord-Cameroun). Implications géodynamiques et paléogéographiques. 1113 J. Afr. Earth Sci. 9, 541-555.

1114 Ngako, V., Njonfang, E., 2011. Plates amalgamation and plate destruction, the western 1115 Gondwana history. Tectonics, Dr. Damien Closson (Ed.), ISBN 978-953-307-545-7, 1116 InTech.

1117 Njanko, T., Nédélec, A., Affaton, P., 2006. Synkinematic high-K calc-alkaline plutons 1118 associated with the Pan-African Central Cameroon shear zone (W-Tibati area): Petrology 1119 and geodynamic significance. Journal of African Earth Sciences 44(4), 494-510.

Njiekak, G., Dörr, W., Tchouankoué, J.P., Zulauf, G., 2008. U-Pb zircon and microfabric data of (meta)granitoids of western Cameroon: Constraints on the timing of pluton emplacement and deformation in the Pan-African belt of central Africa. Lithos 102, 460477.

Njiosseu, E. L. T., Nzenti, J. P., Njanko, T., Kapajika, B., Nédélec, A., 2005b. Reply to 'Comment on New U Pb zircon ages from Tonga (Cameroon): coexisting EburneanTransamazonian (2.1 Ga) and Pan-African (0.6 Ga) imprints' by Sadrack Félix Toteu and Joseph Penaye. C. R. Geoscience 337, 1553-1554.

Njiosseu, E.L.T., Nzenti, J.P., Njanko, T., Kapajika, B., Nédélec, A., 2005a. New U Pb zircon ages from Tonga (Cameroon): coexisting Eburnean-Transamazonian $(2.1 \mathrm{Ga})$ and PanAfrican (0.6 Ga) imprints. C. R. Geoscience 337, 551-562.

Nkoumbou, C., Barbey, P., Yonta-Ngouné, C., Paquette, J.L., Villiéras, F., 2014. Precollisional geodynamic context of the southern margin of the Pan-African fold belt in Cameroon. J. Afr. Earth Sci. 99, 245-260.

Nomo, E.N., Tchameni, R., Vanderhaeghe, O., Fengyue, S., Barbey, P., Tekoum, Lé., Fosso, P.M., Eglinger, A., Fouotsa, N.A.S., 2017. Structure and LA-ICP-MS zircon U-Pb dating of syntectonic plutons emplaced in the Pan-African Banyo-Tcholliré shear zone (central north Cameroun), J. Afr. Earth Sci. 131, 251-271.

1140 Nzenti, J.P., Barbey, P., Bertrand, J.M., Macaudière, J., 1994. La chaîne panafricaine au

1141 Cameroun: cherchons suture et modèle. Abstracts 15eme RST, Nancy, Société 1142 Géologique France, édition Paris, 99. 
1143 Nzenti, J.P., Barbey, P., Tchoua, F.M., 1999. Evolution crustale au Cameroun : éléments pour 1144 un modèle géodynamique de l'orogenèse néoprotérozoïque. Géologie et environnements au Cameroun, collection GEOCAM 2, 397-407.

1146 Owona, S., Schulz, B., Ratschbacher, L., Mvondo-Ondoa, J., Ekodeck, G.E., Tchoua, F., 1147 Affaton, P., 2011. Pan-African metamorphic evolution in the southern Yaounde Group 1148 (Oubanguide Complex, Cameroon) as revealed by EMP-monazite dating and 1149 thermobarometry of garnet metapelites. J. Afr. Earth Sci. 59, 125-139.

1150 Pattison, D.R.M., Bégin, N.J., 1994. Zoning patterns in orthopyroxene and garnet in granulites: implications for geothermometry. J. Metamorph. Geol. 12, 387-410.

Pearce, J., 1996. Sources and settings of granitic rocks. Episodes 19(4), 120-125.

1153 Pearce, J.A., 2008. Geochemical fingerprinting of oceanic basalts with applications to ophiolite classification and the search for Archean oceanic crust. Lithos 100(1), 14-48.

Pearce, J., Harris, N., Tindle, A., 1984. Trace element discrimination diagrams for the tectonic interpretation of granitic rocks. J. Petrol. 259, 956-983.

Peccerillo, A., Taylor, S.R., 1976. Geochemistry of Eocene calc-alkaline volcanic rocks of the Kastamonu area, northern Turkey. Contrib. Mineral. Petrol. 58, 63-81.

Penaye, J., Kröner, A., Toteu, S.F., Van Schmus, W.R., Doumnang, J.C., 2006. Evolution of the Mayo Kebbi region as revealed by zircon dating: an early (ca. $740 \mathrm{Ma}$ ) Pan-African magmatic arc in southwestern Chad. J. Afr. Earth Sci. 44, 530-542.

1162 Penaye, J., Toteu, S.F., Van Schmus, W.R., Nzenti, J.P., 1993. U-Pb and Sm-Nd preliminary geochronologic data on the Yaoundé Series, Cameroon: reinterpretation of the granulitic

Penaye, J., Toteu, S.F., Michard, A., Bertrand, J.M., Dautel, D., 1989. Reliques granulitiques rocks as the suture of a collision in the "Centrafrican" belt. C. R. Acad. Sci. Paris 317, d'âge protérozoïque inférieur dans la zone mobile panafricaine d'Afrique centrale au Cameroun ; géochronologie U-Pb sur zircons. C. R. Acad. Sci. Paris 309, 315-318. Minyem, D., Nsifa, E.N., 2004. The 2.1 Ga West central African belt in Cameroon: extension and evolution. Journal of African Earth Sciences 39(3), 159-164.

Pinna, P., Calvez, J.Y., Abessolo, A., Angel, J.M., Mekoulou, T., Mananga, G., Vernhet, Y., 1994. Neoproterozoic events in the Tcholliré area: Panafrican crustal growth and geodynamics in central northern Cameroon (Adamawa and North provinces). J. Afr. Earth Sci. 18, 347-358. 
1176 Plank, T., Langmuir, C.H., 1998. The chemical composition of subducting sediment and its consequences for the crust and mantle. Chemical Geol. 145, 325-394.

1178 Pouclet, A., Vidal, M., Doumnang, J.C., Vicat, J.-P., Tchameni, R., 2006. Neoproterozoic

1179 evolution in the Southern Chad: Pan-African ocean basin closing, arc accretion and late- to 1180 post-orogenic granitic intrusion. J. Afr. Earth Sci. 44, 543-560.

1181 Ravna, E. K. (2000). Distribution of Fe 2+ and Mg between coexisting garnet and hornblende 1182 in synthetic and natural systems: an empirical calibration of the garnet-hornblende $\mathrm{Fe}-\mathrm{Mg}$ 1183 geothermometer. Lithos, 53(3), 265-277.

1184 Royden, L.H., Burchfiel, B.C., King, R.W., Wang, E., Chen, Z., Shen, F., and Yuping, L., 1185 1997, Surface deformation and lower crustal flow in eastern Tibet: Science, v. 276, p. 7881186790.

1187 Rubatto, D., 2002. Zircon trace element geochemistry: partitioning with garnet and the link 1188 between U-Pb ages and metamorphism. Chemical Geology 184, 123-138

1189 Shand, 1943, Eruptive Rocks. J. Wiley and Sons.

1190 Shervais, J.W., 1982. Ti-V plots and the petrogenesis of modern and ophiolitic lavas. Earth Planet. Sci. Letters 59, 101-118.

1192 Streckeisen, A., Le Maitre, R. W., 1979. A chemical approximation to the modal QAPF 1193 classification of the igneous rocks. N. J. Mineral., Abhandlungen 136, 169-206.

1194 Sun, S.-S., McDonough, W.F., 1989. Chemical and isotopic systematics of oceanic basalts: 1195 implications for mantle composition and processes. In: Saunders A.D. \& Norry M.J. (eds), 1196 Magmatism in the Ocean Basins, Geol. Soc. London Spec. Publ. 42, 313-345.

1197 Taylor, S.R., McLennan, S.M., 1985. The Continental Crust: its Composition and Evolution. Blackwell Scientific Publications, Oxford, 312p.

1199 Tchakounté, J., Eglinger, A., Toteu, S.F., Zeh, A., Nkoumbou, C., Mvondo-Ondoa, J., 1200 Penaye, J., de Wit, M., Barbey, P., 2017. The Adamawa-Yadé domain, a piece of Archaean 1201 crust in the Neoproterozoic Central African Orogenic Belt (Bafia area, Cameroon). 1202 Precambrian Res. 299, 210-229.

1203 Tchameni, R., Pouclet, A., Penaye, J., Ganwa, A.A., Toteu, S.F., 2006. Petrography and 1204 geochemistry of the Ngaoundéré Pan-African granitoids in Central North Cameroon: Implications for sources and geological setting. J. Afr. Earth Sci. 44, 511-529. 
Tikoff, B., Teyssier, C., 1994. Strain modeling of displacement-field partitioning in transpressional orogens. Journal of Structural Geology 16 (11), 1575-1588.

Toteu, S.F., Yongue Fouateu, R., Penaye, J., Tchakounté, J., Seme Mouangue, A.C., Van Schmus, W.R., Deloule, E., Stendal, H., 2006a. U-Pb dating of plutonic rocks involved in the nappe tectonic in southern Cameroon: consequence for the Pan-African orogenic evolution of the central African fold belt. J. Afr. Earth Sci. 44, 479-493.

Toteu, S.F., Penaye, J., Deloule, E., Van Schmus, W.R., Tchameni, R., 2006b. Diachronous evolution of volcano-sedimentary basins north of the Congo craton: Insights from $\mathrm{U}-\mathrm{Pb}$ ion microprobe dating of zircons from the Poli, Lom and Yaoundé Groups (Cameroon). J. Afr. Earth Sci. 44, 428-442.

Toteu, S.F., Penaye, J., 2005. Comment on New U-Pb zircon ages from Tonga (Cameroon): coexisting Eburnean-Transamazonian $(2.1 \mathrm{Ga})$ and Pan-African (0.6 Ga) imprints by EL Tanko Njiosseu et al. [CR Geoscience 337 (2005) 551-562]. C.R. Geoscience 337, 15511552.

Toteu, S.F., Penaye, J., Poudjom Djomani, Y., 2004. Geodynamic evolution of the PanAfrican belt in central Africa with special reference to Cameroon. Can. J. Earth Sci. 41, $73-85$.

Toteu, S.F., Van Schmus, W.R., Penaye, J., Michard, A., 2001. New U-Pb and Sm-Nd data from north-central Cameroon and its bearing on pre-Pan African history of central Africa. Precambrian Res. 108, 45-73.

Toteu, S.F., Van Schmus, W.R., Penaye, J., Nyobé, J.B., 1994. U-Pb and Sm-Nd evidence for Eburnian and Pan-African high-grade metamorphism in cratonic rocks of SouthernCameroon. Precambrian Res. 67, 321-347.

Toteu, S.F., Michard, A., Bertrand, J.M., Rocci, G., 1987. U-Pb dating of Precambrian rocks from northern Cameroon, orogenic evolution and chronology of the Pan-African belt of central Africa. Precambrian Res. 37, 71-87.

Turlin, F., Deruy, C., Eglinger, A., Vanderhaeghe, O., André-Mayer, A.-S., Poujol, M., Moukhsil, A., Solgadi, F., 2018. A 70 Ma record of suprasolidus conditions in the large, hot, long-duration Grenville Orogen. Terra Nova, doi:10.1111/ter.12330.

Vanderhaeghe O., Teyssier C., 2001. Partial melting and flow of orogens. Tectonophysics $342,451-472$.

Vanderhaeghe, O., 2001. Melt segregation, pervasive melt migration and magma mobility in the continental crust: the structural record from pores to orogens. Physics and Chemistry of the Earth, Part A: Solid Earth and Geodesy 26 (4-5), 213-223. 
1243 Vanderhaeghe, O., 2009. Migmatites, granites and orogeny: Flow modes of partially-molten rocks and magmas associated with melt/solid segregation in orogenic belts. Tectonophysics 477, 119-134.

Vanderhaeghe O. (2012): Thermal-mechanical evolution of orogenic belts at convergent plate boundaries: a reappraisal of the orogenic cycle, Journal of Geodynamics, 56-57, pp. 124145.

Van Schmus, W.R., Oliveira, E.P., Da Silva Filho, A.F., Toteu, S.F., Penaye, J., Guimarães, I.P., 2008. Proterozoic links between the Borborema Province, NE Brazil, and the Central African Fold Belt. In: Pankhurst, R.J., Trouw, R.A.J., Brito Neves, B.B., De Wit, M.J. (Eds), West Gondwana: Pre-Cenozoic Correlations Across the South Atlantic Region. Geol. Soc. London Spec. Publ. 294, 69-99.

Whalen, J.B., Frost, C., 2013. The Q-ANOR diagram: a tool for the petrogenetic and tectonomagmatic characterization of granitic suites. Geol. Soc. Amer., Abstracts with Programs 45(3), 24.

Williams, I.S., Claesson, S., 1987. Isotopic evidence for the Precambrian provenance and Caledonian metamorphism of high grade paragneisses from the Seve Nappes, Scandinavian Caledonides. II. Ion microprobe zircon Ube zircon Un micropro to Mineralogy and Petrology 97, 205-217.

Yakymchuk, C., Brown, M., 2014. Behaviour of zircon and monazite during crustal melting. Journal of the Geological Society 171 (4), 465-479.

Zeh, A., Gerdes, A., Barton Jr., J.M., Klemd, R., 2010. U-Th-Pb and Lu-Hf systematicsof zircon from TTG's, leucosomes, anorthosites and quartzites of the LimpopoBelt (South Africa): constraints for the formation, recycling, and metamorphismof Paleoarchean crust. Precambrian Research 179, 50-68. sediments of the Pieterburg Greenston belt (South Africa) - Is there a common provenance with the Witwatersrand basin? Precambrian Res. 204, 46-56. 
Figure 1. (a) Tectonic map of Western Gondwana showing the position of the Central African Orogenic Belt pinched in between the West-African craton, the Congo craton and the Sahara metacraton (modified after Küster and Liégeois, 2001; Toteu et al., 2004). The position of the map at the scale of Africa is shown in the inset. (b) Geology of the Central African Orogenic in Cameroon and southern Chad (modified after Toteu et al., 2001; Pinna et al., 1994; Toteu et al., 2004). The location of the map is shown by a grey rectangle on figure 1a. Abbreviation: $\mathrm{CD}=$ Central Domain; $\mathrm{SZ}=$ Shear Zone.

Figure 2. Geodynamic models for the tectonic-magmatic evolution of the Central African Orogenic Belt. (a) The "crustal reworking" model considers that the Central African Orogenic Belt essentially corresponds to reworked pre-existing Archaean and Paleoproterozoic cratons after inversion of a continental rift. In this model, magmatism is dominantly issued from partial melting of the crust triggered by delamination of the subcontinental lithospheric mantle. (b) The "magmatic-tectonic accretion" model considers that the Central African Orogenic Belt is made of accreted terranes (magmatic arc, back-arc, ophiolite) along an active margin, which does not preclude the presence of reworked blocks of the former cratons. In this model, magmatism is attributed to both, crustal- and mantle- sources.

Figure 3. Geological map of the Mbé-Sassa-Mbersi area (position indicated by a grey rectangle on figure $1 \mathrm{~b})$.

Figure 4. Geological map of the Ndong Benue area. Samples described for petrology, geochemistry and/or geochronology are indicated by white letters and numbers.

Figure 5. Migmatitic intermediate to felsic gneisses of the Ndong Benue area. (a) and (b) show amphibolite layers boudinaged and transposed in the foliation of migmatitic intermediate to felsic gneisses. (c) Detail of a migmatitic intermediate gneiss with alternations of leucosomes and mesosomes defining the syn-migmatitic foliation. (d) Amphibolites crosscut by intrusive foliated tonalite. (e) Gneisses with an intermediate to felsic composition cross-cut by a pinched and swelled granitic dike partially transposed into the foliation. (f)

1303 Migmatitic intermediate to felsic gneisses partially transposed into NE-SW trending sinistral shear zones. 
1306 Figure 6. Metabasites of the Mbé - Sassa-Mbersi area. (a) Migmatitic garnet amphibolite of 1307 the Karna quarry with tonalitic leucosome underlining the syn-migmatitic foliation. (b) 1308 Metagabbro of the Ndgon Benue area with tonalite filling interboudins' neck.

Figure 7. Paragneisses of the Ndong Benue area. (a) Alternations of metagreywackes and metapelites delineating a $S_{0 / n}$ foliation and folds with an axial planar syn-migmatitic $S_{n+1}$ foliation. (b) Migmatitic garnet paragneiss with leucosomes in the XZ plane of deformation showing a sigmoid shape consistent with a sinsitral sense of shear. (c) Migmatitic paragneiss with folded discordant leucosome and an axial planar syn-migmatitic foliation. (d) Migmatitic paragneiss with partially transposed discordant leucosome in textural continuity with concordant leucosome. (e) Migmatitic paragneiss with a syn-migmatitic $S_{n+1}$ foliation underlined by mesosome/leucosome alternations superimposed on the transposed $\mathrm{S}_{0 / \mathrm{n}}$ foliation marked by metagreywackes/metapelites alternations. (f) Granitic vein transposed into the $S_{n+1}$ foliation of a migmatitic paragneiss.

Figure 8. Composite foliation of the intermediate to felsic gneisses. (a) Foliation $S_{n+1}$ marked by alternations of mica-rich and quartz-feldspar-rich layers, both comprising feldspar porphyroclasts. (b) Amphibolite boudin wrapped in the $S_{n+1}$ gneissic foliation. (c) Metagabbro boudin wrapped in the $S_{n+1}$ gneissic foliation. (d) Relictual $S_{n}$ foliation preserved from transposition. (e) Partially transposed granitic vein discordant on the $S_{n+1}$ gneissic foliation marked by alternations of porphyroclast-rich and porphyroclast-poor layers. (f) Pinched-andswelled pegmatitic layer transposed in a mylonitic foliation including feldspar porphyroclasts.

Figure 9. Biotite granite of the Ndong Benue area. (a) Granitic dikes with sharp contacts discordant on the $\mathrm{S}_{\mathrm{n}+1}$ foliation of the host intermediate gneiss. (b) Granitic veins concordant to the $S_{n+1}$ foliation of the host intermediate gneiss with a fabric grading from magmatic to solid-state. (c) Granitic veins concordant and discordant to the $S_{n+1}$ foliation of the host intermediate gneiss with a solid-state fabric. (d) Epidote veins with diffuse boundaries crosscutting the $S_{n+1}$ foliation of an amphibolite at the contact of a biotite granite. 
1338 a white rectangle in Fig. 9a. (c) Shallow-dipping syn-migmatitic foliation in an amphibolite.

1339 (d) Shallow-dipping cataclastic fabric in an amphibolite.

1341 Figure 11. Ndom Benue mylonitic shear zone. (a) Shallow dipping mylonitic foliation 1342 marked by alternating layers of intermediate and felsic gneisses. (b) Feldspar porphyroclasts 1343 wrapped in the mylonitic foliation with a sigmoid shape in the XZ plane of deformation 1344 consistent with a top-to-the WSW. (c) Ultramylonitic foliation bearing a WSW-ESE trending 1345 stretching lineation. (d) Sheath folds with an axis parallel to the WSW-ESE trending lineation.

Figure 12. Dextral shear zones of the Ndong Benue area. (a) Deflection of the $S_{n+1}$ foliation into a 10-cm thick mylonitic shear zone consistent with a dextral sense of shear. (b) Discordant granitic vein in a position of a tension gash relative to a dextral shear zone.

Figure 13. Photomicrographs of selected metamorphic rocks from the Mbé - Sassa-Mbersi area. (a) hornblendite (Mayo Lou); (b) amphibolite (Ndong Benue); (c) garnet amphibolite (Mayo Lou); (d) Garnet-sillimanite gneiss (Ndong Benue); (e) tonalitic orthogneiss (Mayo Mbanna); and (f) leucogneiss (Falaise). See text for further explanation.

Figure 14. $\mathrm{Fe}_{2} \mathrm{O}_{3}+\mathrm{CaO}+\mathrm{TiO}_{2}$ vs. $\mathrm{Al}_{2} \mathrm{O}_{3}$ plot (La Roche, 1965) for the metamorphic rocks of the Mbé - Sassa-Mbersi area. Dark grey solid line = igneous trend $(\mathrm{ga}=$ gabbro, $\mathrm{di}=$ diorite, $\mathrm{gd}=$ granodiorite, $\mathrm{gr}=$ granite $)$.

Figure 15. (a) $\mathrm{MgO}-\mathrm{FeO}^{*}$; (b) $\mathrm{CaO}-\mathrm{SiO}_{2}$; (c) $\mathrm{FeO} * / \mathrm{MgO}-\mathrm{SiO}_{2}$; and (d) $\mathrm{Th} / \mathrm{Yb}-\mathrm{Nb} / \mathrm{Yb}$ for the metabasic rocks of the Mbé - Sassa-Mbersi area. $\mathrm{FeO}^{*}=$ total iron as $\mathrm{FeO}$; tholeiitic/calc-alkaline divide from Miyashiro (1974); mantle array, N-MORB, E-MORB and OIB from Pearce (1996). Subducted sediments from Pearce (2008).

Figure 16. REE patterns normalized to chondrite (Evensen et al., 1978) and multi-element plot normalized to the primitive mantle (Sun and Macdonough, 1989) for the metabasic rocks of the Mbé - Sassa-Mbersi area. (a) and (b) cumulate rocks (hornblendite, metagabbro and type 1 amphibolite); (c) and (d) type 2 amphibolites; (e) and (f) type 3 amphibolites. See text for further explanation. 
1371 Figure 17. REE patterns normalized to chondrite (Evensen et al., 1978) and multi-element 1372 plot normalized to the primitive mantle (Sun and Macdonough, 1989) for the garnet gneisses 1373 and calc-silicate rocks ( $\mathrm{a}$ and $\mathrm{b}$ ), and for the intermediate to felsic orthogneisses ( $\mathrm{c}$ and $\mathrm{d}$ ). 1374 NASC (North American Shale Composite) from Gromet et al. (1984); Phanerozoic 1375 graywackes from Taylor and McLennan (1985).

1377 Figure 18. Classification diagrams for the plutonic rocks of the Mbé - Sassa-Mbersi area: (a) 1378 Q'-ANOR; (b) A/NK vs. A/CNK $\left[\mathrm{Al}_{2} \mathrm{O}_{3} /\left(\mathrm{Na}_{2} \mathrm{O}+\mathrm{K}_{2} \mathrm{O}\right)\right.$ vs. $\left.\mathrm{Al}_{2} \mathrm{O}_{3} /\left(\mathrm{CaO}+\mathrm{Na} 2 \mathrm{O}+\mathrm{K}_{2} \mathrm{O}\right)\right]$; (c) $1379 \mathrm{FeO} /\left(\mathrm{FeO}+\mathrm{MgO}\right.$ ) vs. $\mathrm{SiO}_{2}$; (d) $\mathrm{K}_{2} \mathrm{O}$ vs. $\mathrm{SiO}_{2}$; and $\mathrm{Rb}$ vs. $\mathrm{Y}+\mathrm{Nb}$ (after Streckeisen and Le 1380 Maitre, 1979; Whalen and Frost, 2013; Shand, 1943; Frost et al., 2001; Peccerillo and Taylor, 1381 1976; and Pearce et al., 1984).

1383 Figure 19. REE patterns normalized to chondrite (Evensen et al., 1978) and multi-element 1384 plot normalized to the primitive mantle (Sun and Macdonough, 1989) for the plutonic rocks of 1385 the Mbé - Sassa-Mbersi area. (a) and (b) microgranular enclaves; (c) and (d) hornblendebiotite granite; (e) and (f) tonalite and trondhjemite; (g) and (h) biotite granite.

Figure 20. Perple_X $P-T$ pseudosection for the metasedimentary rock sample NB14-01. $\mathrm{M}_{1}$ : peak metamorphic conditions determined from garnet core composition; $\mathrm{M}_{2}$ : retrograde conditions determined from garnet rim composition. Isopleths of garnet also shown.

Figure 21. Zircon $\mathrm{U}-\mathrm{Pb}$ diagrams for some metamorphic and magmatic rocks from the Mbé Sassa-Mbersi area: (a) and (b) Concordia diagram for garnet gneiss sample NB14-02; (c) distribution plot of ${ }^{206} \mathrm{~Pb} /{ }^{238} \mathrm{U}$ (grains $<1000 \mathrm{Ma}$ ) and ${ }^{207} \mathrm{~Pb} /{ }^{235} \mathrm{U}$ (grains $>1000 \mathrm{Ma}$ ) ages for the same garnet gneiss; (d) and (e) Concordia diagrams for garnet amphibolite sample NB1411a and NB14-11b; (f) Concordia diagram for the tonalite sample NG14-02; (g) Concordia 1397 diagram for the hornblende-biotite granite sample M13-01D; and (h) Concordia diagram for pegmatite granite sample NB14-09. 


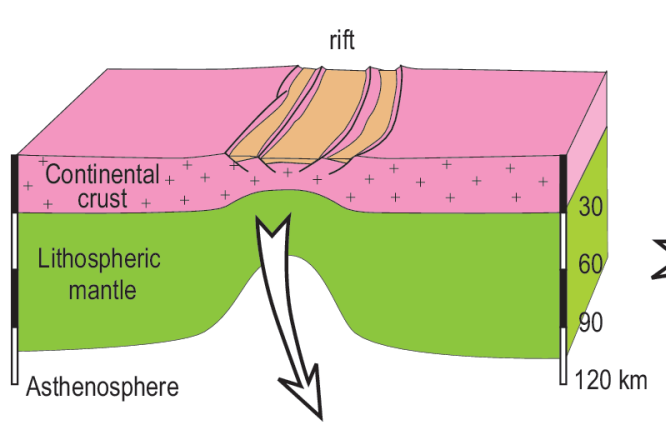

(a) Crustal reworking

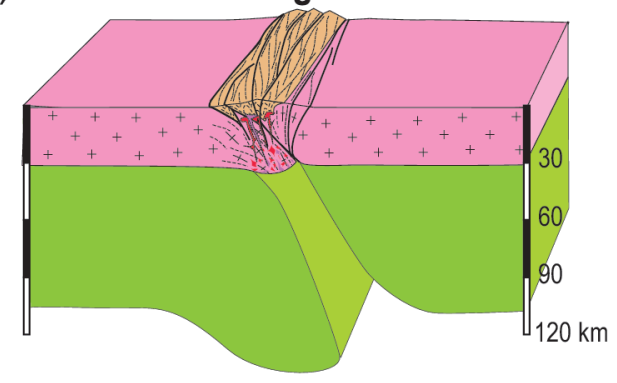

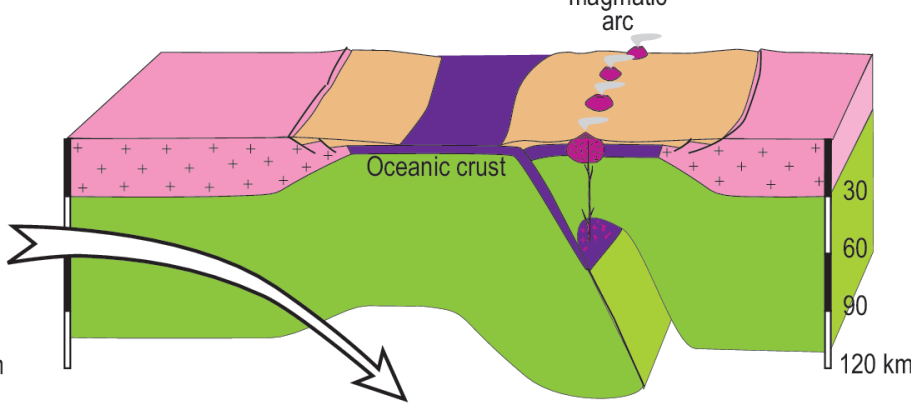

(b) Magmatic-tectonic accretion

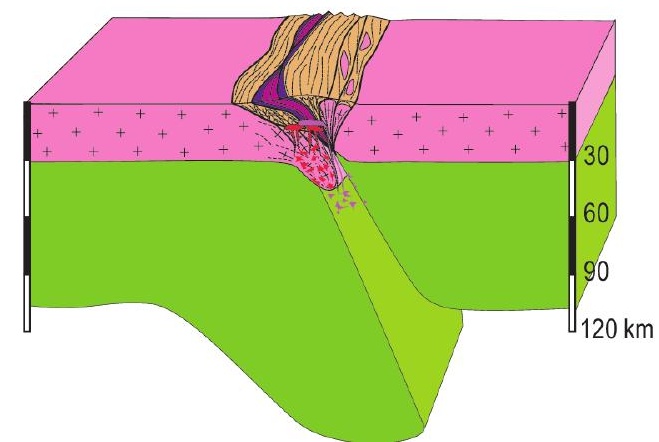




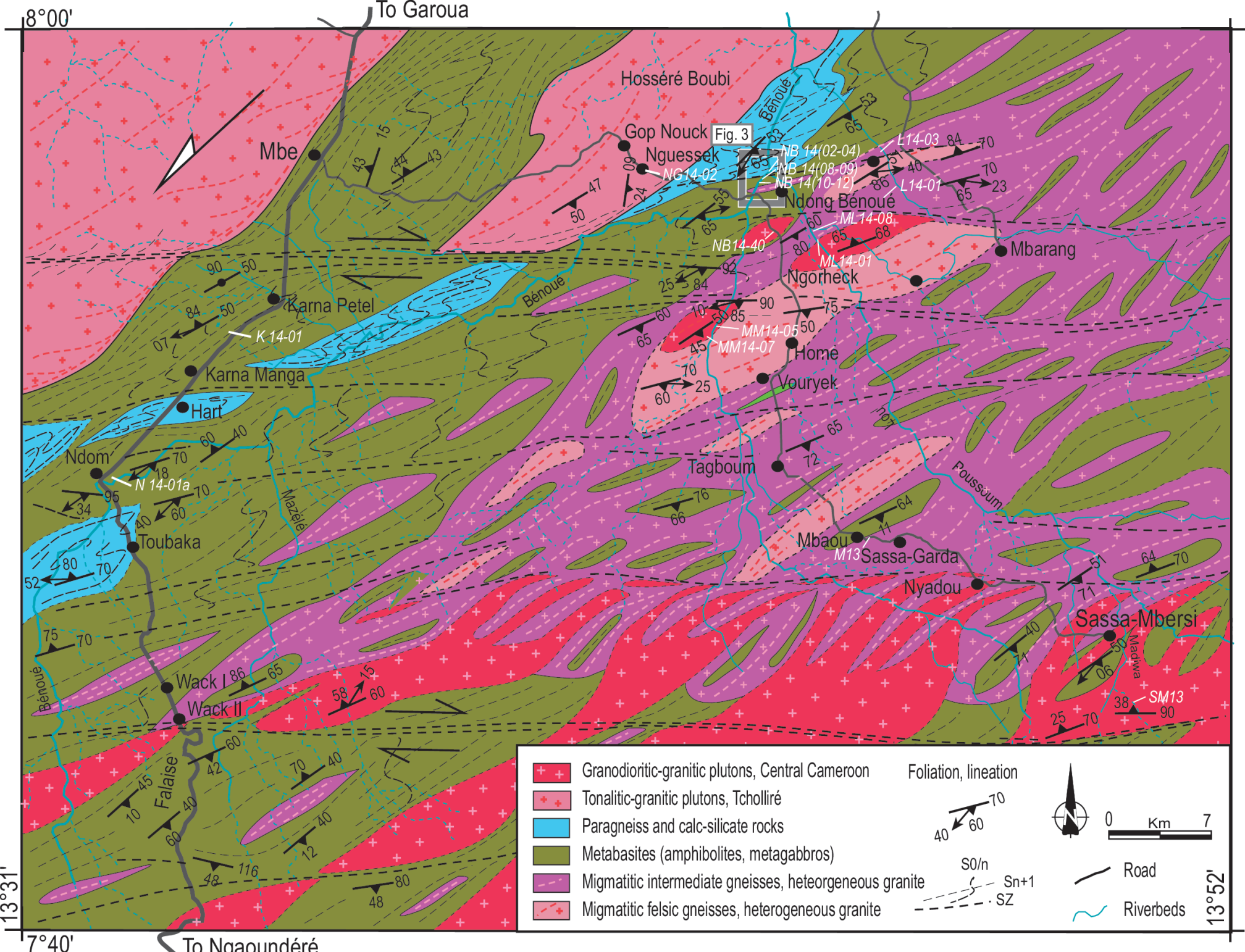

\footnotetext{
$7^{\circ} 40^{\prime}$

To Ngaoundéré
}

\section{Figure 3}




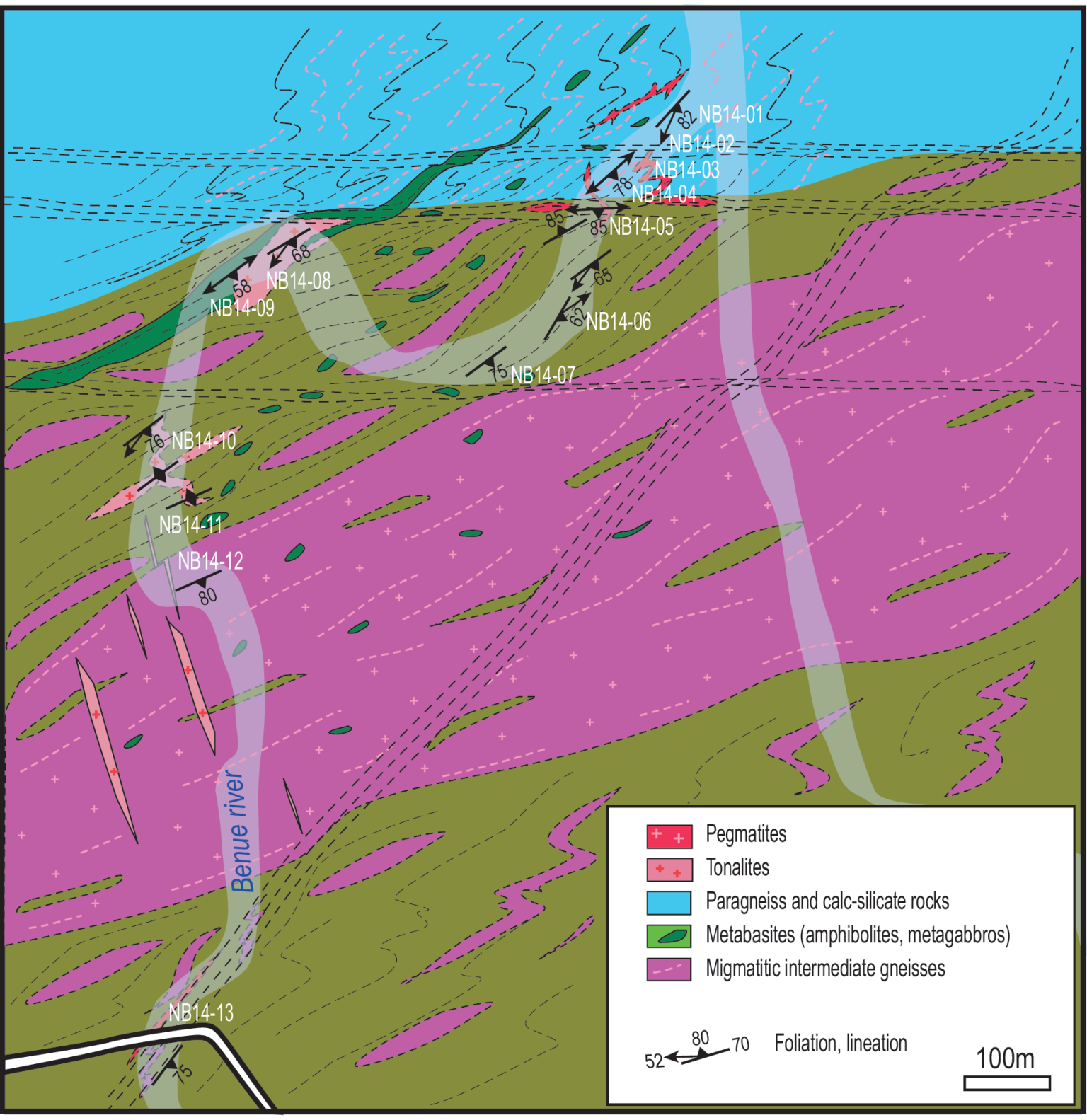

Figure 4 


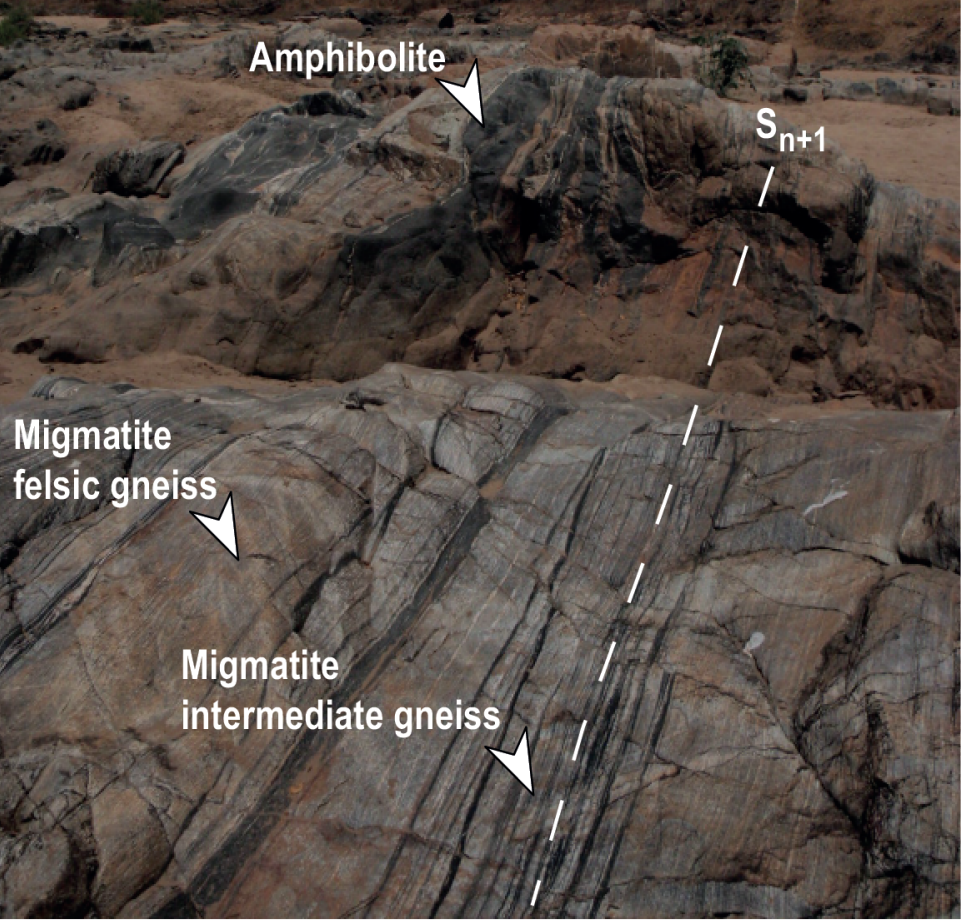

(c) Ndong Benue

Migmatitic intermediate gneiss
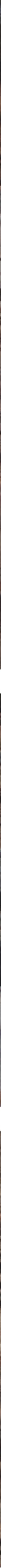

(d) Ndong Benue

E>

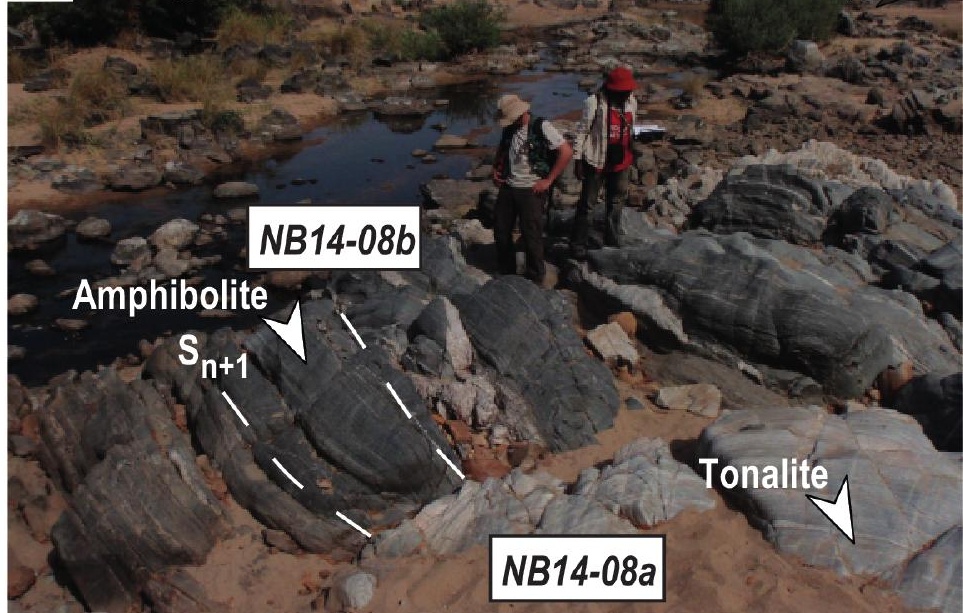

Figure 5

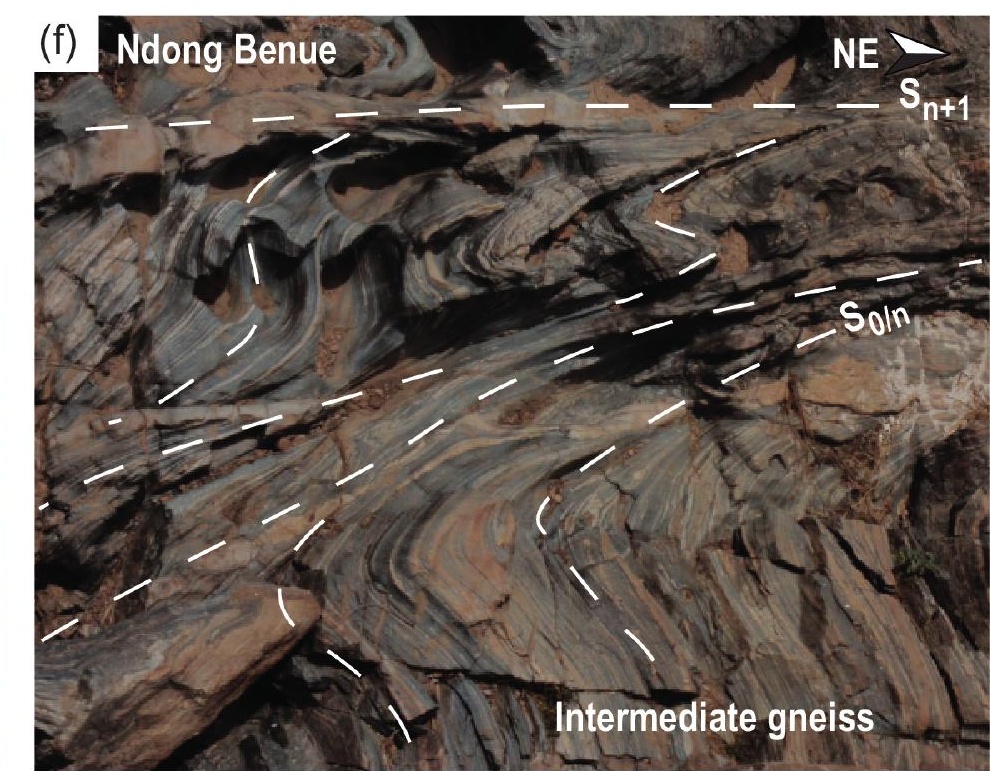

Migmatite Amphibolite 
(a)

Karna quarry

SE $>$ (b) Nolong Benue

$s_{n+1}$ 1.

(1) 20
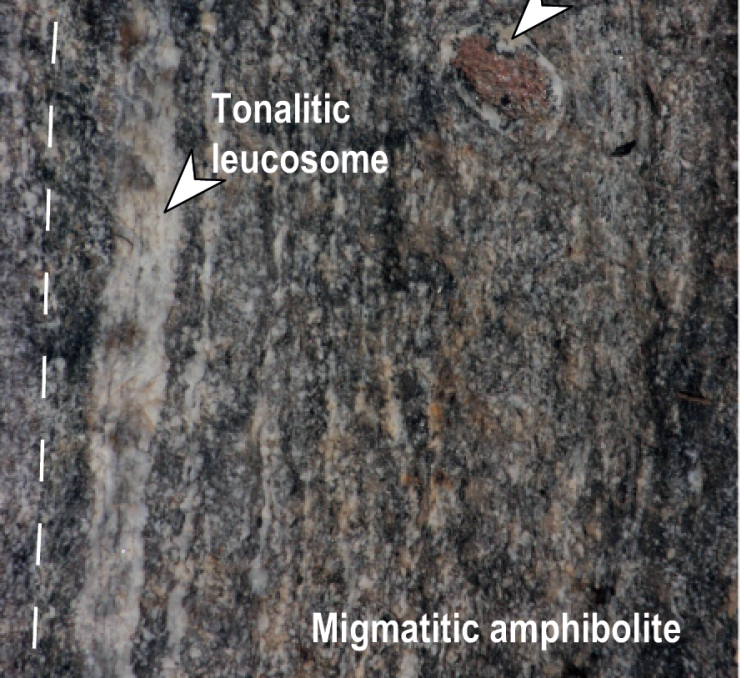

Garnet

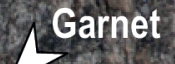

\section{$S_{n+1}$}

1.8

1
SE

NB14-08b

I Garnet-metagabbro

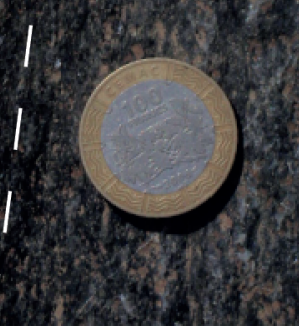


(a) Ndong Benue
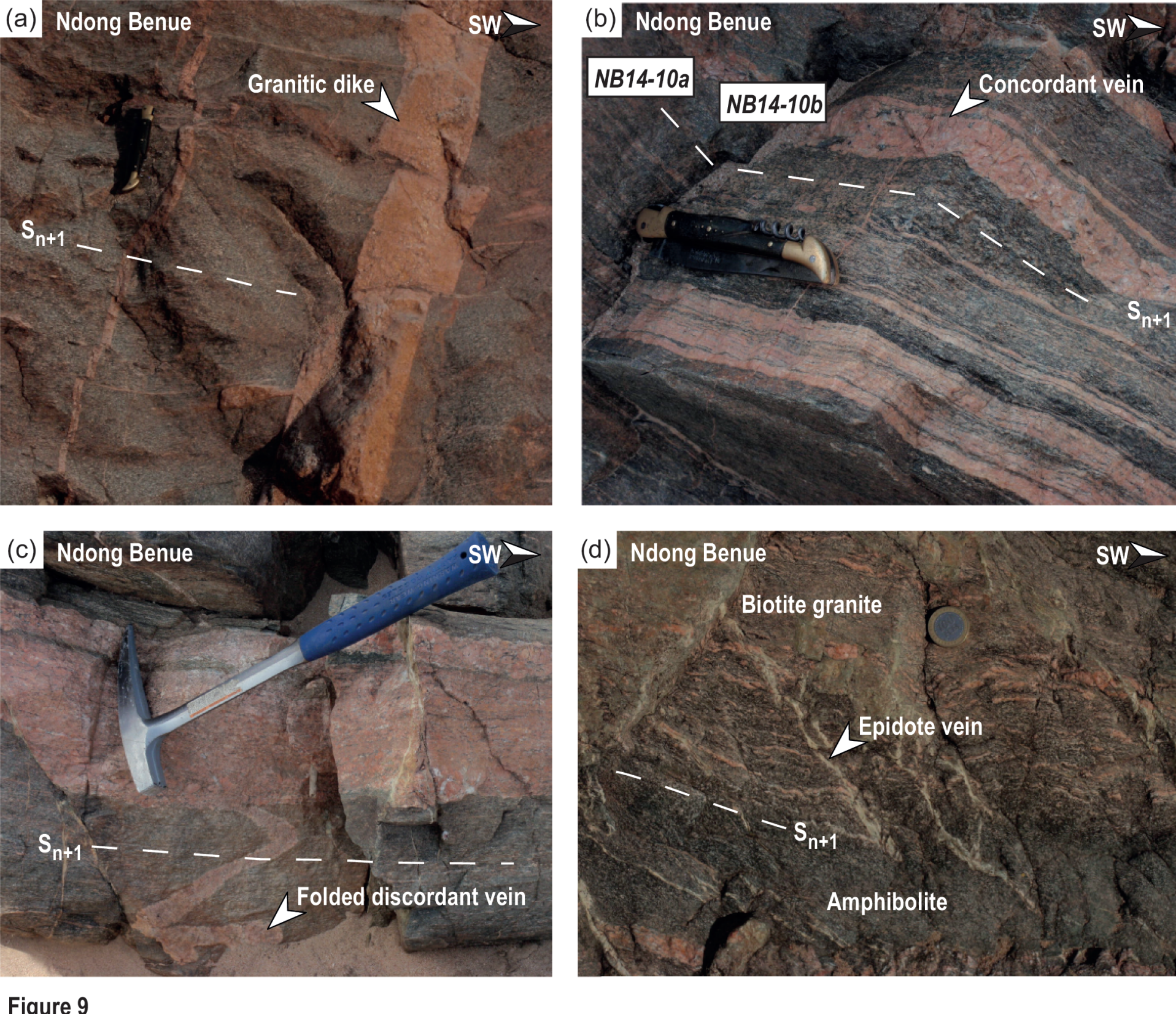

(c) Ndong Benue
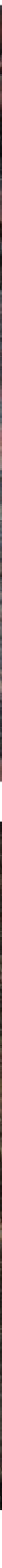

Figure 9

50


(a) Ndong Benue

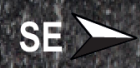

Intermediate gneiss
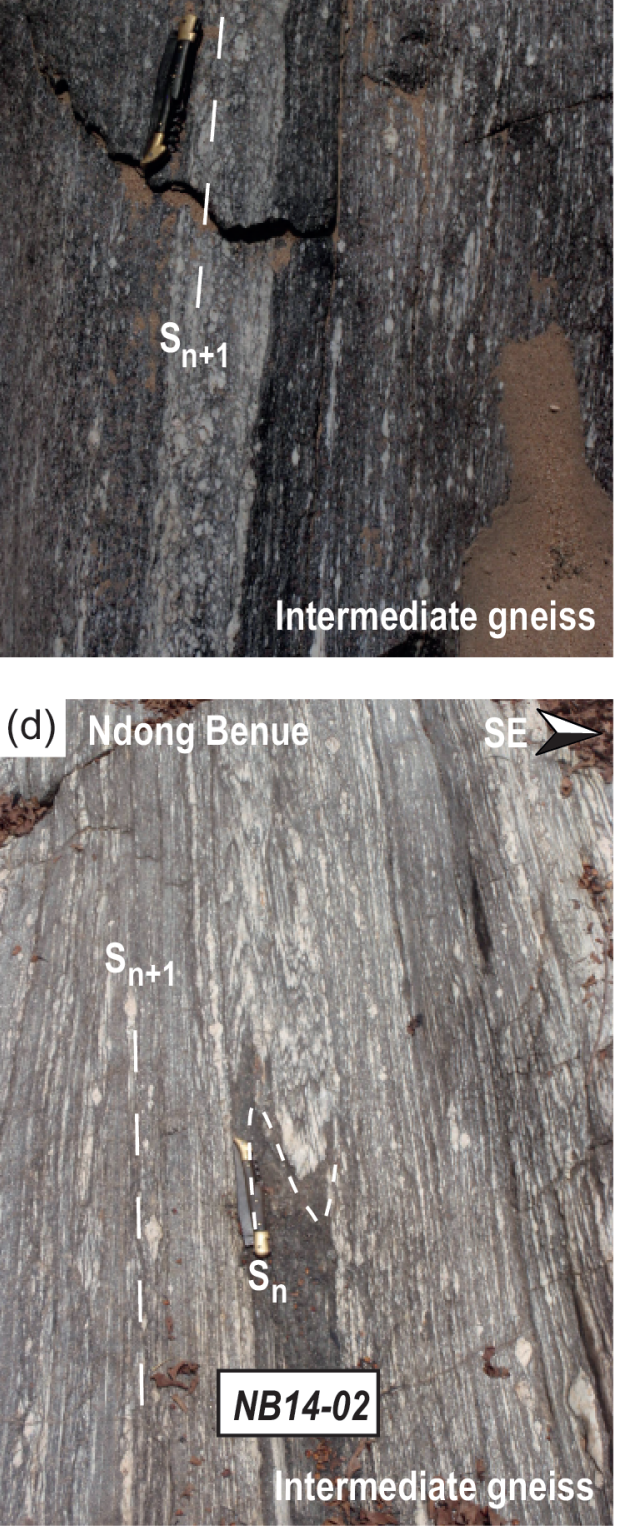

(b) Nolong Benue

SE

(c) Ndong Benue
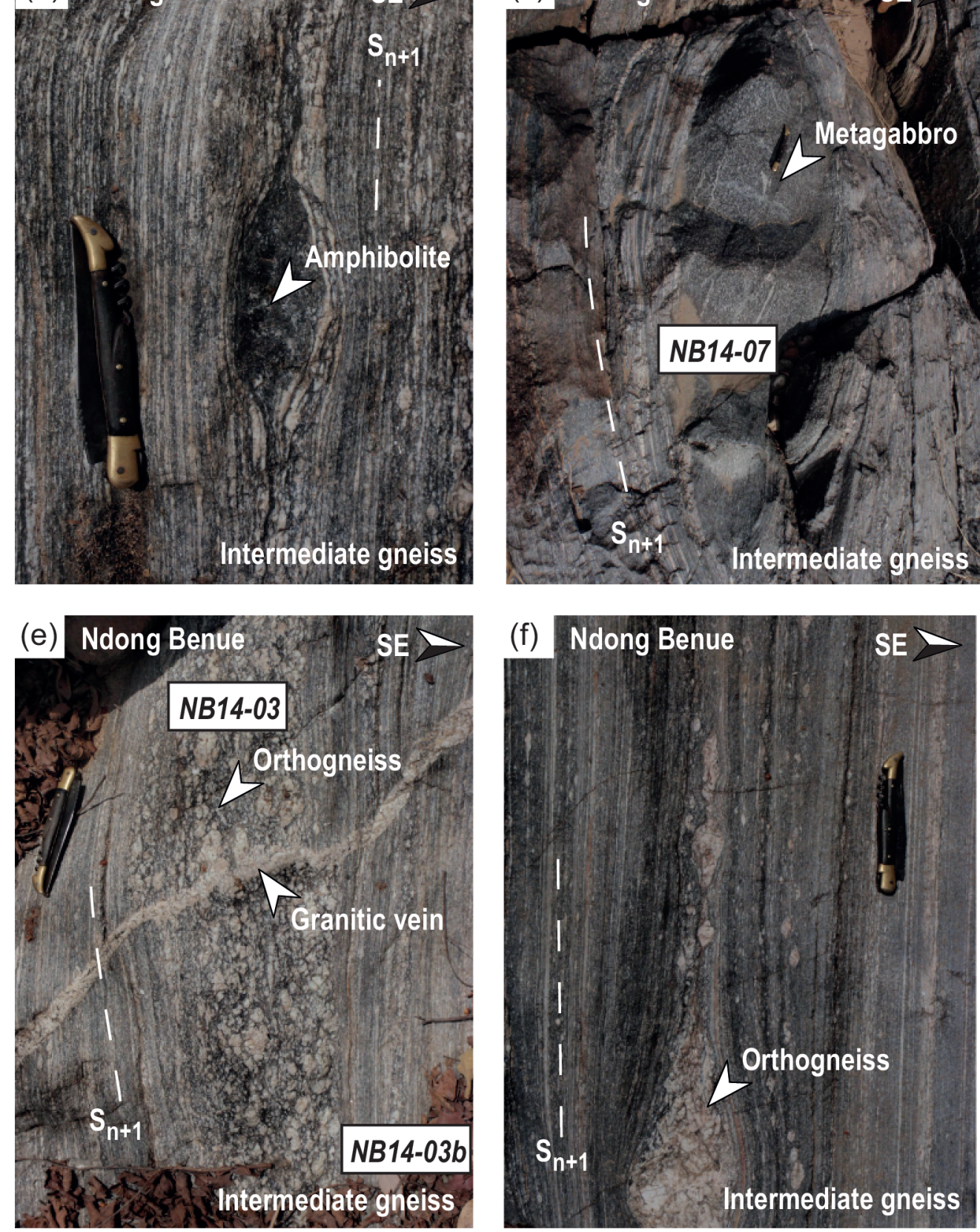

Figure 9 


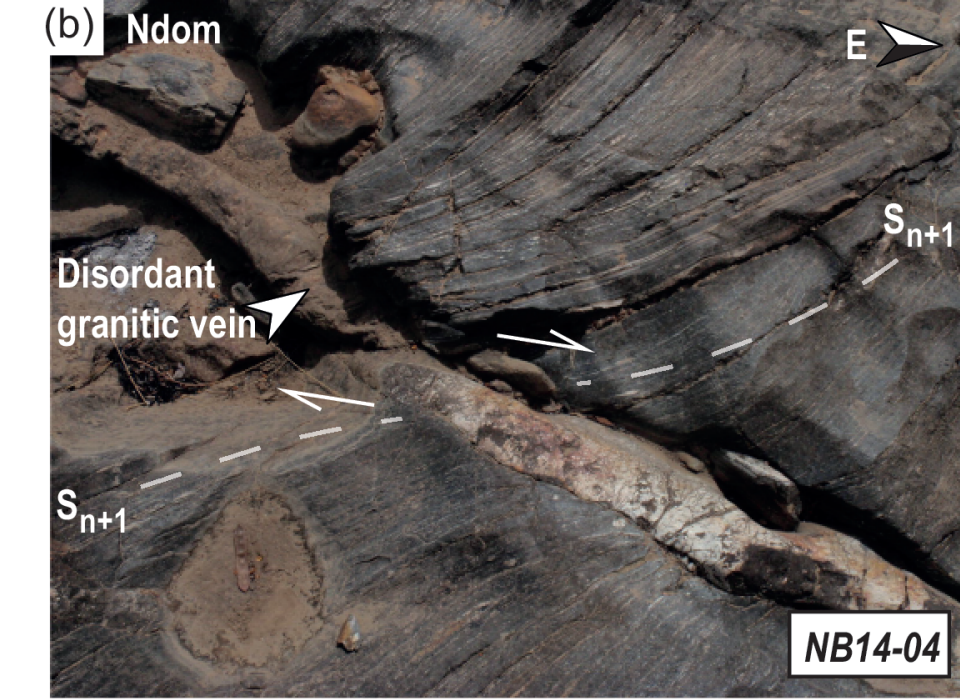

\section{Figure 12}
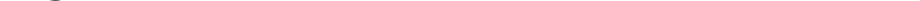

NB

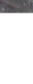




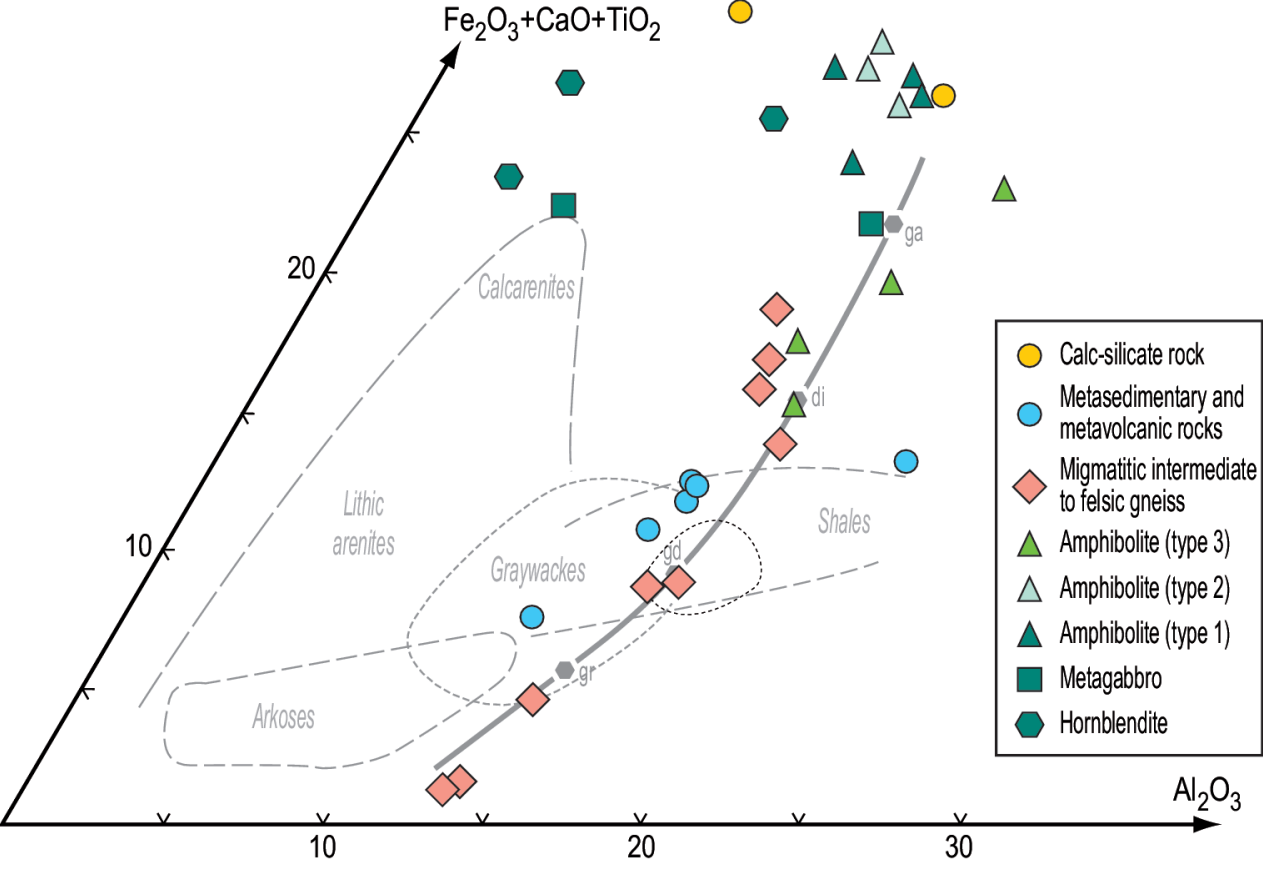

Figure 14 


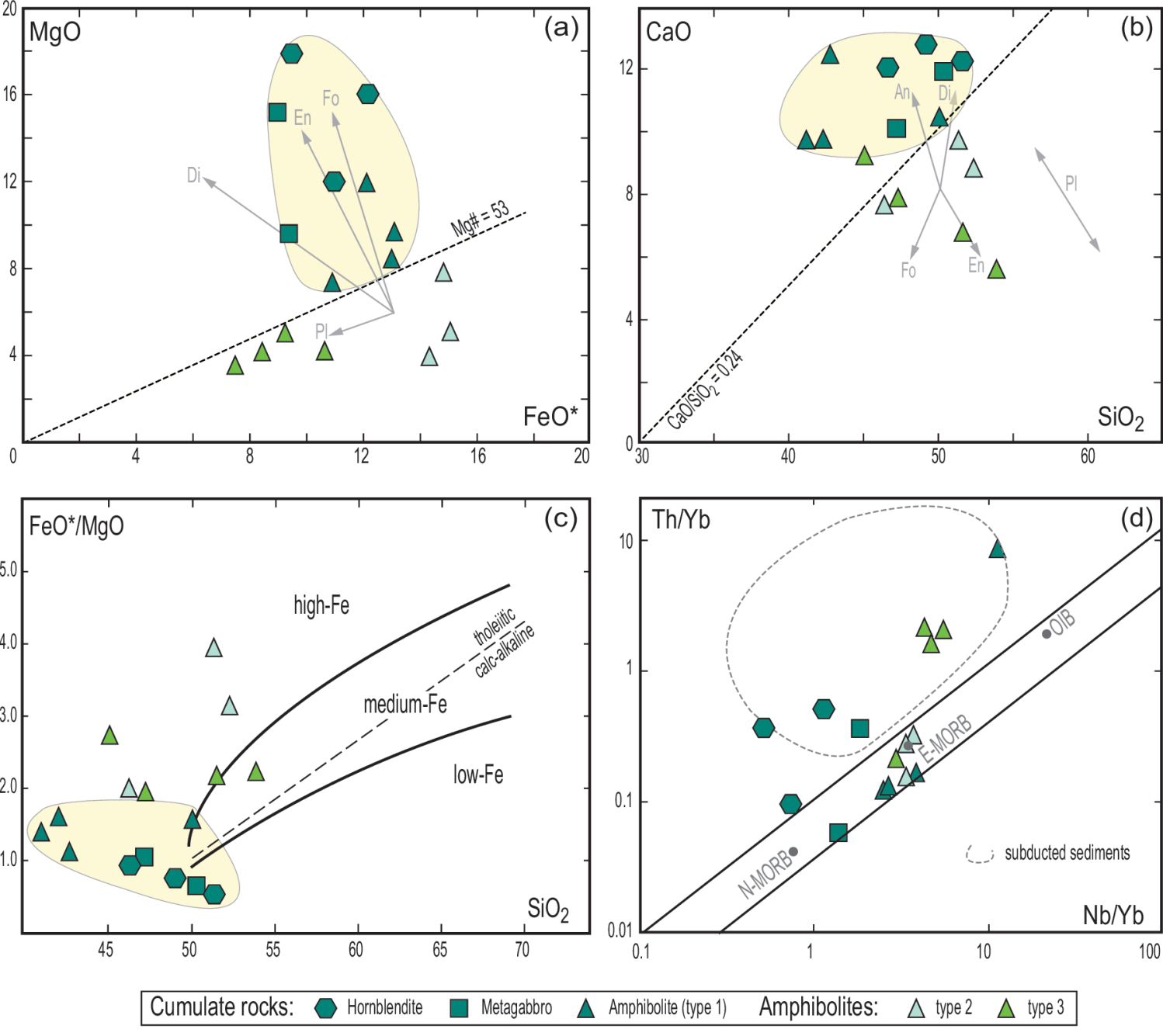

Figure 15 


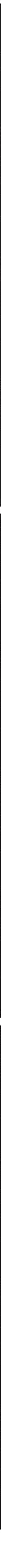

Figure 16 


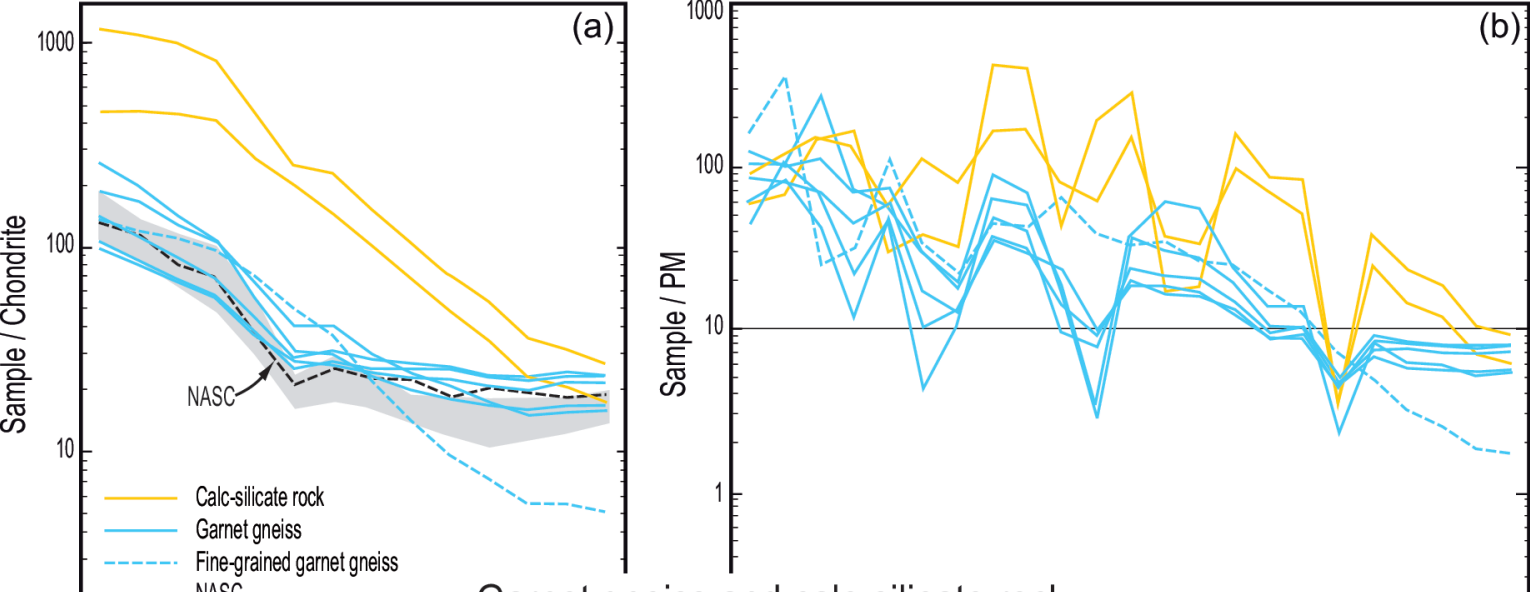
NASC

Phanerozoic graywackes

Garnet gneiss and calc-silicate rock
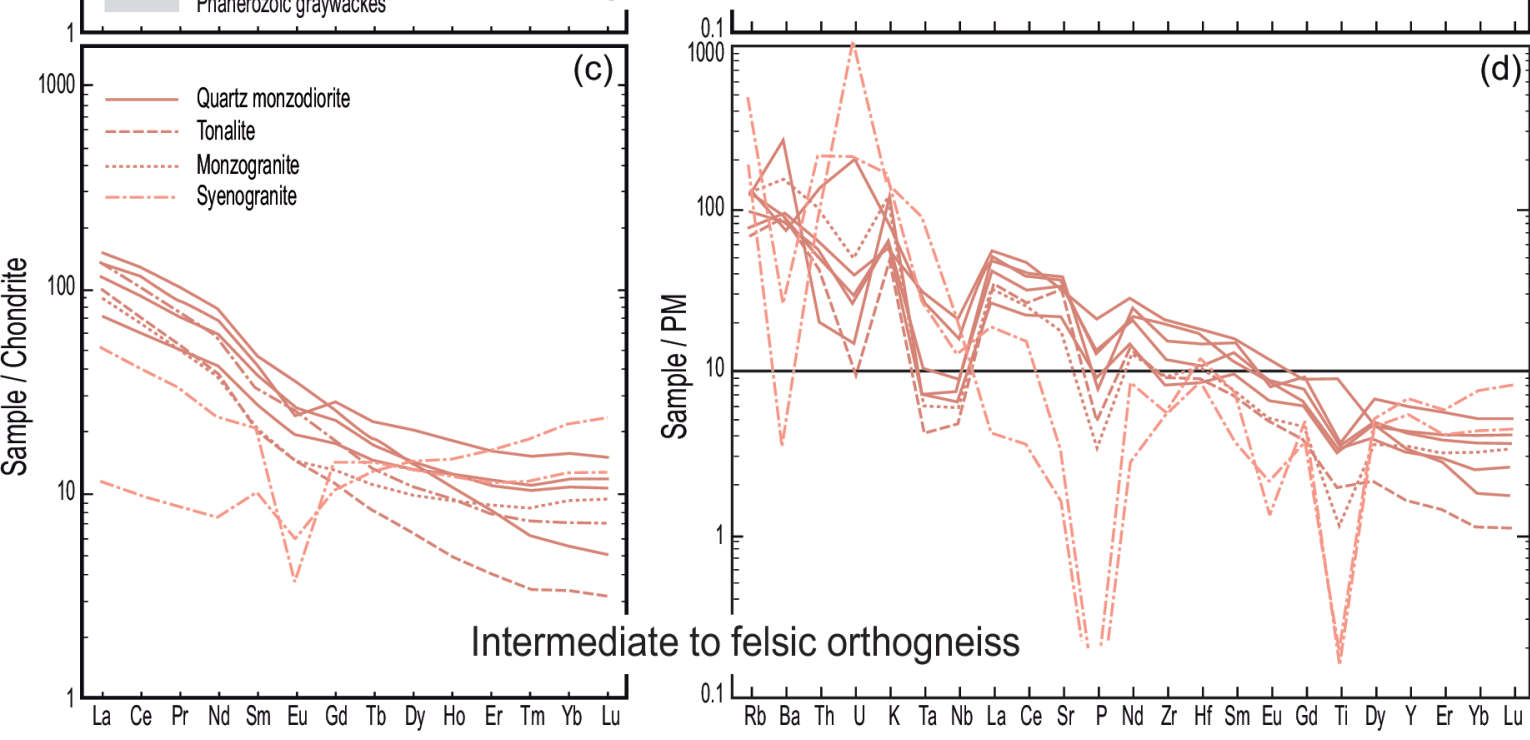

Figure 17 

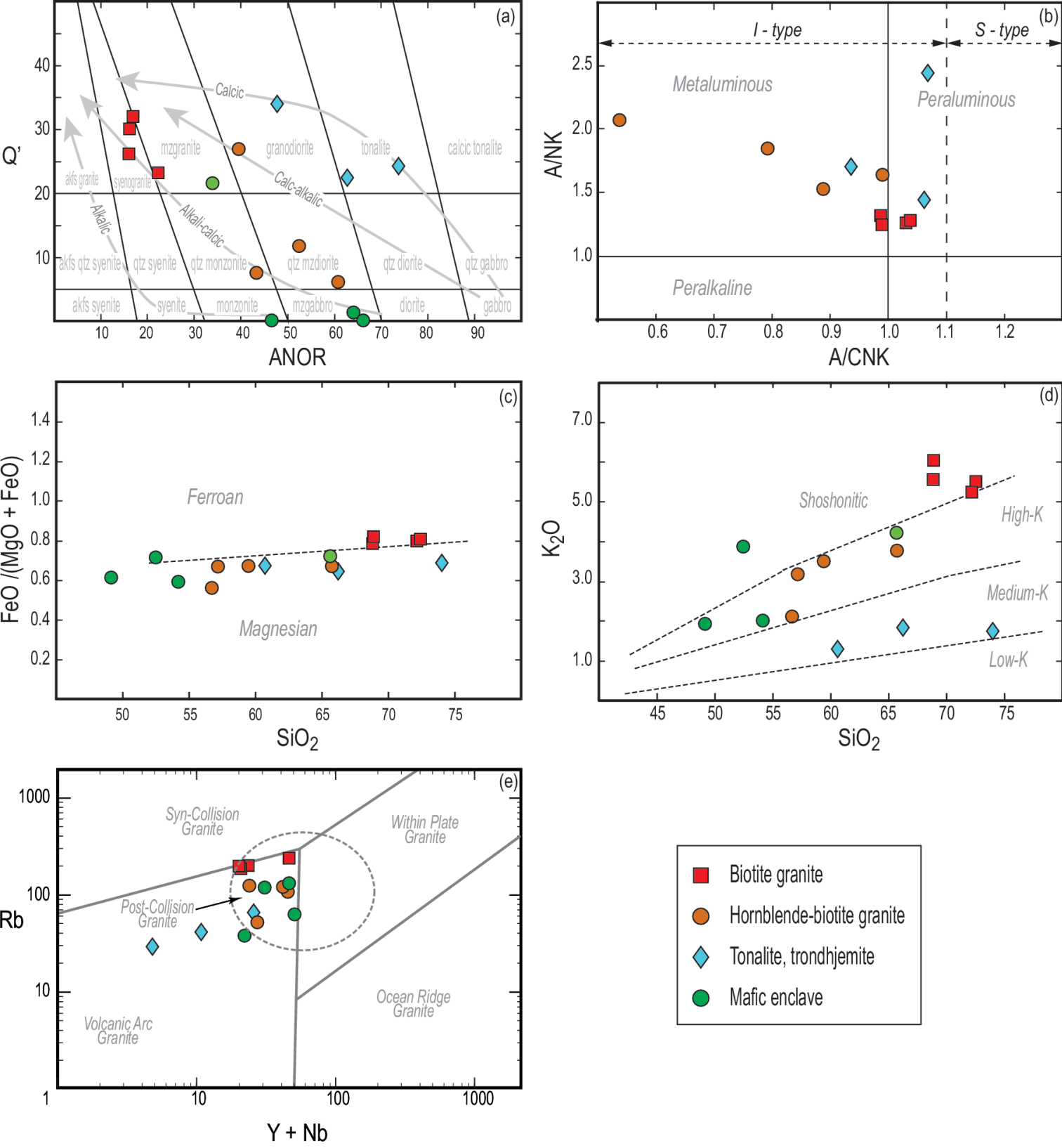
- Biotite granite
- Hornblende-biotite granite
$\diamond$ Tonalite, trondhiemite
- Mafic enclave

\section{Figure 18}




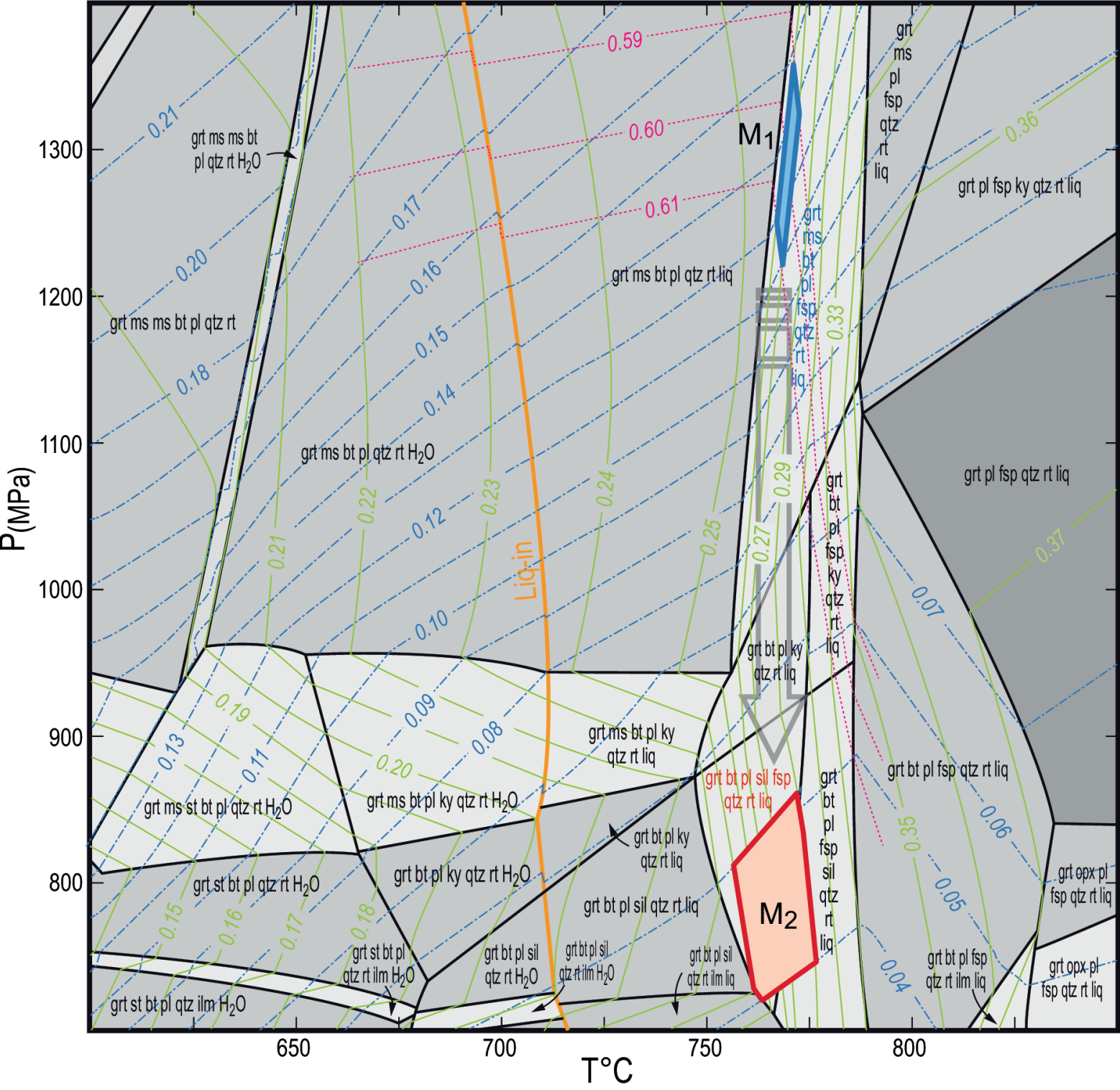


Table 13. Major (wt.\%) and trace element (ppm) composition of metabasic rocks from the Mbé - SassaMbersi area.

\begin{tabular}{|c|c|c|c|c|c|c|c|c|c|}
\hline Sample & NB14 & NB14 & ML14 & NB14 & NB14 & NB14 & NB14 & ML14 & ML14 \\
\hline & 05 & 44 & 08 & $07 \mathrm{a}$ & $11 \mathrm{c}$ & $11 d$ & $11 \mathrm{~b}$ & $01 \mathrm{a}$ & 04 \\
\hline Type & hbd & hbd & hbd & mga & mga & amp & amp & amp & $\mathrm{amp}$ \\
\hline $\mathrm{SiO}_{2}$ & 46.57 & 49.20 & 51.64 & 47.28 & 50.45 & 41.21 & 42.15 & 42.86 & 50.17 \\
\hline $\mathrm{Al}_{2} \mathrm{O}_{3}$ & 11.28 & 4.12 & 4.01 & 16.14 & 6.16 & 14.90 & 15.53 & 12.23 & 14.27 \\
\hline $\mathrm{Fe}_{2} \mathrm{O}_{3}{ }^{\text {tot }}$ & 12.24 & 13.49 & 10.59 & 10.49 & 9.99 & 14.64 & 14.47 & 13.50 & 12.19 \\
\hline $\mathrm{MnO}$ & 0.21 & 0.25 & 0.20 & 0.14 & 0.19 & 0.17 & 0.22 & 0.12 & 0.20 \\
\hline $\mathrm{MgO}$ & 11.95 & 16.00 & 17.82 & 9.50 & 15.21 & 9.54 & 8.38 & 11.76 & 7.25 \\
\hline $\mathrm{CaO}$ & 12.01 & 12.75 & 12.27 & 10.09 & 11.91 & 9.61 & 9.71 & 12.43 & 10.39 \\
\hline $\mathrm{Na}_{2} \mathrm{O}$ & 1.63 & 0.50 & 0.46 & 3.04 & 1.19 & 2.01 & 1.96 & 1.37 & 3.06 \\
\hline $\mathrm{K}_{2} \mathrm{O}$ & 1.39 & 0.31 & 0.38 & 1.09 & 0.65 & 1.65 & 2.11 & 1.26 & 1.03 \\
\hline $\mathrm{TiO}_{2}$ & 1.16 & 0.61 & 0.53 & 1.22 & 0.55 & 2.62 & 2.23 & 1.30 & 1.19 \\
\hline $\mathrm{P}_{2} \mathrm{O}_{5}$ & 0.16 & 0.06 & ld & ld & 0.11 & 0.31 & 0.48 & 0.89 & 0.25 \\
\hline LOI & 2.25 & 2.68 & 2.33 & 2.08 & 3.21 & 2.73 & 2.75 & 1.79 & 0.71 \\
\hline Total & 100.84 & 99.96 & 100.24 & 101.07 & 99.61 & 99.38 & 99.99 & 99.51 & 100.71 \\
\hline $\mathrm{Ba}$ & 296 & 39 & 60 & 335 & 157 & 924 & 1269 & 258 & 321 \\
\hline $\mathrm{Co}$ & 56 & 64 & 67 & 51 & 66 & 54 & 51 & 51 & 40 \\
\hline $\mathrm{Cr}$ & 155 & 1147 & 691 & 254 & 1457 & 104 & 118 & 523 & 225 \\
\hline $\mathrm{Ga}$ & 16.4 & 12.6 & 9.9 & 19.8 & 11.1 & 23.0 & 26.1 & 28.4 & 22.2 \\
\hline Hf & 3.1 & 2.1 & 2.4 & 1.2 & 2.3 & 2.8 & 3.1 & 6.0 & 2.5 \\
\hline $\mathrm{Nb}$ & 4.1 & 1.1 & 0.8 & 3.0 & 2.9 & 8.3 & 9.9 & 8.3 & 10.8 \\
\hline $\mathrm{Ni}$ & 50 & 309 & 341 & 97 & 230 & 30 & 65 & 172 & 96 \\
\hline $\mathrm{Rb}$ & 28 & 5 & 9 & 19 & 11 & 37 & 47 & 22 & 11 \\
\hline $\mathrm{Sc}$ & 56 & 42 & 55 & 51 & 43 & 43 & 39 & 33 & 35 \\
\hline $\mathrm{Sn}$ & 1.5 & 1.7 & 1.3 & 1.3 & 1.1 & 2.4 & 3.2 & 3.4 & 3.0 \\
\hline $\mathrm{Sr}$ & 210 & 114 & 84 & 709 & 92 & 543 & 671 & 137 & 873 \\
\hline $\mathrm{Ta}$ & 0.3 & 0.1 & 0.1 & 0.2 & 0.2 & 0.4 & 0.4 & 0.4 & 0.6 \\
\hline Th & 1.8 & 0.1 & 0.6 & 0.1 & 0.6 & 0.4 & 0.5 & 5.8 & 0.4 \\
\hline $\mathrm{U}$ & 0.3 & 0.1 & 0.2 & 0.1 & 0.3 & 0.1 & 0.1 & 0.9 & 0.1 \\
\hline $\mathrm{V}$ & 366 & 218 & 178 & 298 & 189 & 331 & 289 & 243 & 297 \\
\hline W & 0.3 & 0.3 & 0.6 & 0.5 & - & 0.5 & 0.3 & 0.5 & - \\
\hline $\mathrm{Y}$ & 33.8 & 17.1 & 16.9 & 23.4 & 16.9 & 39.9 & 47.0 & 13.0 & 32.5 \\
\hline $\mathrm{Zn}$ & 101 & 175 & 104 & 99 & 89 & 139 & 184 & 253 & 137 \\
\hline $\mathrm{Zr}$ & 107 & 49 & 61 & 27 & 71 & 69 & 91 & 219 & 74 \\
\hline $\mathrm{La}$ & 15.21 & 8.52 & 7.70 & 6.02 & 11.03 & 18.21 & 24.08 & 50.87 & 30.61 \\
\hline $\mathrm{Ce}$ & 37.58 & 29.01 & 26.13 & 22.35 & 29.51 & 54.63 & 72.78 & 109.10 & 86.47 \\
\hline $\operatorname{Pr}$ & 5.29 & 4.95 & 4.18 & 4.32 & 4.31 & 8.66 & 11.58 & 12.81 & 12.30 \\
\hline $\mathrm{Nd}$ & 23.82 & 24.76 & 19.62 & 23.74 & 19.19 & 42.53 & 54.41 & 49.68 & 52.37 \\
\hline $\mathrm{Sm}$ & 6.03 & 6.35 & 4.85 & 6.46 & 4.52 & 10.86 & 13.11 & 8.45 & 10.87 \\
\hline $\mathrm{Eu}$ & 1.65 & 1.53 & 1.00 & 1.67 & 1.12 & 2.88 & 3.37 & 1.85 & 2.64 \\
\hline Gd & 5.79 & 4.76 & 3.91 & 5.27 & 3.90 & 9.46 & 11.17 & 6.25 & 7.95 \\
\hline $\mathrm{Tb}$ & 0.93 & 0.66 & 0.57 & 0.78 & 0.57 & 1.35 & 1.58 & 0.74 & 1.12 \\
\hline Dy & 6.09 & 3.64 & 3.39 & 4.60 & 3.33 & 7.96 & 9.32 & 3.42 & 6.20 \\
\hline Ho & 1.33 & 0.69 & 0.66 & 0.91 & 0.66 & 1.59 & 1.84 & 0.53 & 1.20 \\
\hline $\mathrm{Er}$ & 3.57 & 1.67 & 1.70 & 2.33 & 1.71 & 3.97 & 4.59 & 1.15 & 3.07 \\
\hline $\mathrm{Tm}$ & 0.53 & 0.23 & 0.24 & 0.32 & 0.24 & 0.53 & 0.61 & 0.12 & 0.43 \\
\hline $\mathrm{Yb}$ & 3.64 & 1.48 & 1.56 & 2.12 & 1.56 & 3.24 & 3.78 & 0.72 & 2.79 \\
\hline $\mathrm{Lu}$ & 0.56 & 0.22 & 0.23 & 0.31 & 0.23 & 0.47 & 0.56 & 0.10 & 0.42 \\
\hline
\end{tabular}


Table 13. (Continued)

\begin{tabular}{|c|c|c|c|c|c|c|c|}
\hline Sample & $\begin{array}{c}\text { NB14 } \\
11 \mathrm{a} \\
\text { grt amp }\end{array}$ & $\begin{array}{c}\text { NB14 } \\
08 \mathrm{c} \\
\text { grt amp }\end{array}$ & $\begin{array}{l}\text { NB14 } \\
11 \mathrm{e} \\
\text { amp }\end{array}$ & $\begin{array}{c}\text { NB14 } \\
08 b \\
\text { grt amp }\end{array}$ & $\begin{array}{c}\text { N14 } \\
01 a-2 \\
\text { amp }\end{array}$ & $\begin{array}{c}\text { NB14 } \\
10 \\
\text { grt amp }\end{array}$ & $\begin{array}{c}\text { N14 } \\
\text { 01a-1 } \\
\text { amp }\end{array}$ \\
\hline $\mathrm{SiO}_{2}$ & 45.22 & 46.45 & 47.35 & 51.43 & 51.59 & 52.37 & 53.87 \\
\hline $\mathrm{Al}_{2} \mathrm{O}_{3}$ & 19.78 & 15.05 & 17.85 & 13.29 & 16.24 & 13.55 & 17.14 \\
\hline $\mathrm{Fe}_{2} \mathrm{O}_{3}{ }^{\text {tot }}$ & 11.90 & 16.57 & 10.34 & 16.06 & 9.38 & 16.83 & 8.40 \\
\hline $\mathrm{MnO}$ & 0.14 & 0.19 & 0.15 & 0.23 & 0.15 & 0.20 & 0.13 \\
\hline $\mathrm{MgO}$ & 3.97 & 7.72 & 4.90 & 3.70 & 3.93 & 4.92 & 3.45 \\
\hline $\mathrm{CaO}$ & 9.18 & 7.53 & 7.77 & 9.60 & 6.55 & 8.61 & 5.40 \\
\hline $\mathrm{Na}_{2} \mathrm{O}$ & 3.82 & 2.61 & 3.65 & 1.39 & 3.94 & 0.84 & 4.41 \\
\hline $\mathrm{K}_{2} \mathrm{O}$ & 1.31 & 0.75 & 2.27 & 0.25 & 3.38 & 0.27 & 3.62 \\
\hline $\mathrm{TiO}_{2}$ & 1.67 & 1.72 & 1.44 & 2.45 & 1.45 & 1.66 & 1.33 \\
\hline $\mathrm{P}_{2} \mathrm{O}_{5}$ & 1.17 & 0.22 & 0.64 & 0.25 & 0.95 & 0.18 & 0.77 \\
\hline LOI & 2.49 & 2.04 & 2.24 & 1.15 & 1.42 & 0.76 & 1.50 \\
\hline Total & 100.65 & 100.82 & 98.61 & 99.78 & 98.99 & 100.18 & 100.02 \\
\hline $\mathrm{Ba}$ & 932 & 280 & 1181 & 69 & 2988 & 38 & 3173 \\
\hline $\mathrm{Co}$ & 29 & 55 & 30 & 52 & 28 & 55 & 27 \\
\hline $\mathrm{Cr}$ & 17 & 157 & 40 & 75 & 592 & 194 & 690 \\
\hline $\mathrm{Ga}$ & 26.5 & 19.9 & 26.4 & 20.7 & 25.6 & 17.1 & 26.3 \\
\hline $\mathrm{Hf}$ & 4.2 & 3.0 & 6.8 & 4.6 & 8.3 & 3.0 & 8.5 \\
\hline $\mathrm{Nb}$ & 7.4 & 7.9 & 12.2 & 12.3 & 12.1 & 8.7 & 12.1 \\
\hline $\mathrm{Ni}$ & 7.8 & 102 & 19 & 58 & 357 & 131 & 415 \\
\hline $\mathrm{Rb}$ & 32 & 18 & 70 & 6 & 55 & 6 & 55 \\
\hline $\mathrm{Sc}$ & 16 & 49.8 & 23.5 & 40.6 & 18.0 & 46.2 & 13.6 \\
\hline Sn & 2.0 & 4.6 & 3.3 & 3.5 & 4.1 & 1.8 & 3.7 \\
\hline $\mathrm{Sr}$ & 1318 & 206 & 954 & 290 & 1691 & 140 & 1597 \\
\hline $\mathrm{Ta}$ & 0.3 & 0.6 & 1.0 & 1.1 & 0.6 & 0.7 & 0.6 \\
\hline $\mathrm{Th}$ & 0.5 & 0.6 & 3.9 & 1.0 & 5.6 & 0.4 & 4.2 \\
\hline $\mathrm{U}$ & 0.1 & 0.2 & 0.6 & 0.4 & 0.9 & 0.3 & 0.8 \\
\hline V & 165 & 302 & 212 & 303 & 161 & 311 & 144 \\
\hline W & - & 0.7 & ld & 1.4 & 1.6 & 1.1 & 1.9 \\
\hline Y & 32.1 & 22.8 & 30.0 & 35.1 & 34.8 & 27.1 & 26.4 \\
\hline $\mathrm{Zn}$ & 135 & 181 & 141 & 132 & 156 & 147 & 137 \\
\hline $\mathrm{Zr}$ & 187 & 103 & 293 & 175 & 395 & 108 & 376 \\
\hline Sample & $\begin{array}{c}\text { NB14 } \\
11 \mathrm{a}\end{array}$ & $\begin{array}{c}\text { NB14 } \\
08 \mathrm{c}\end{array}$ & $\begin{array}{c}\text { NB14 } \\
11 \mathrm{e}\end{array}$ & $\begin{array}{c}\text { NB14 } \\
08 b\end{array}$ & $\begin{array}{c}\text { N14 } \\
01 \mathrm{a}-2\end{array}$ & $\begin{array}{c}\text { NB14 } \\
10\end{array}$ & $\begin{array}{c}\text { N14 } \\
\text { 01a-1 }\end{array}$ \\
\hline $\mathrm{La}$ & 35.27 & 9.98 & 59.91 & 13.73 & 90.21 & 9.72 & 65.76 \\
\hline $\mathrm{Ce}$ & 91.73 & 25.76 & 128.40 & 34.46 & 199.90 & 24.77 & 147.60 \\
\hline $\operatorname{Pr}$ & 12.42 & 3.56 & 15.37 & 5.02 & 24.82 & 3.52 & 18.13 \\
\hline $\mathrm{Nd}$ & 54.45 & 15.77 & 59.84 & 22.90 & 98.10 & 16.37 & 72.20 \\
\hline $\mathrm{Sm}$ & 11.04 & 3.98 & 11.46 & 6.27 & 17.62 & 4.40 & 12.80 \\
\hline $\mathrm{Eu}$ & 2.94 & 1.27 & 2.82 & 1.98 & 4.28 & 1.62 & 3.04 \\
\hline $\mathrm{Gd}$ & 8.63 & 4.00 & 8.32 & 6.55 & 11.71 & 4.70 & 8.65 \\
\hline $\mathrm{Tb}$ & 1.18 & 0.67 & 1.13 & 1.06 & 1.47 & 0.77 & 1.09 \\
\hline Dy & 6.48 & 4.36 & 6.12 & 6.69 & 7.44 & 4.93 & 5.60 \\
\hline Ho & 1.24 & 0.93 & 1.16 & 1.40 & 1.35 & 1.04 & 1.01 \\
\hline $\mathrm{Er}$ & 3.06 & 2.44 & 2.91 & 3.57 & 3.34 & 2.70 & 2.57 \\
\hline $\mathrm{Tm}$ & 0.40 & 0.35 & 0.39 & 0.50 & 0.43 & 0.39 & 0.33 \\
\hline $\mathrm{Yb}$ & 2.48 & 2.37 & 2.57 & 3.35 & 2.78 & 2.55 & 2.15 \\
\hline $\mathrm{Lu}$ & 0.37 & 0.35 & 0.37 & 0.49 & 0.42 & 0.40 & 0.33 \\
\hline
\end{tabular}

$\mathrm{hbd}=$ hornblendite $; \mathrm{mga}=$ metagabbro $; \mathrm{amp}=$ amphibolite grt = garnet. 
Table 11. Major (wt.\%) and trace element (ppm) composition of metasedimentary and metavolcanic rocks from the Mbé - Sassa-Mbersi area.

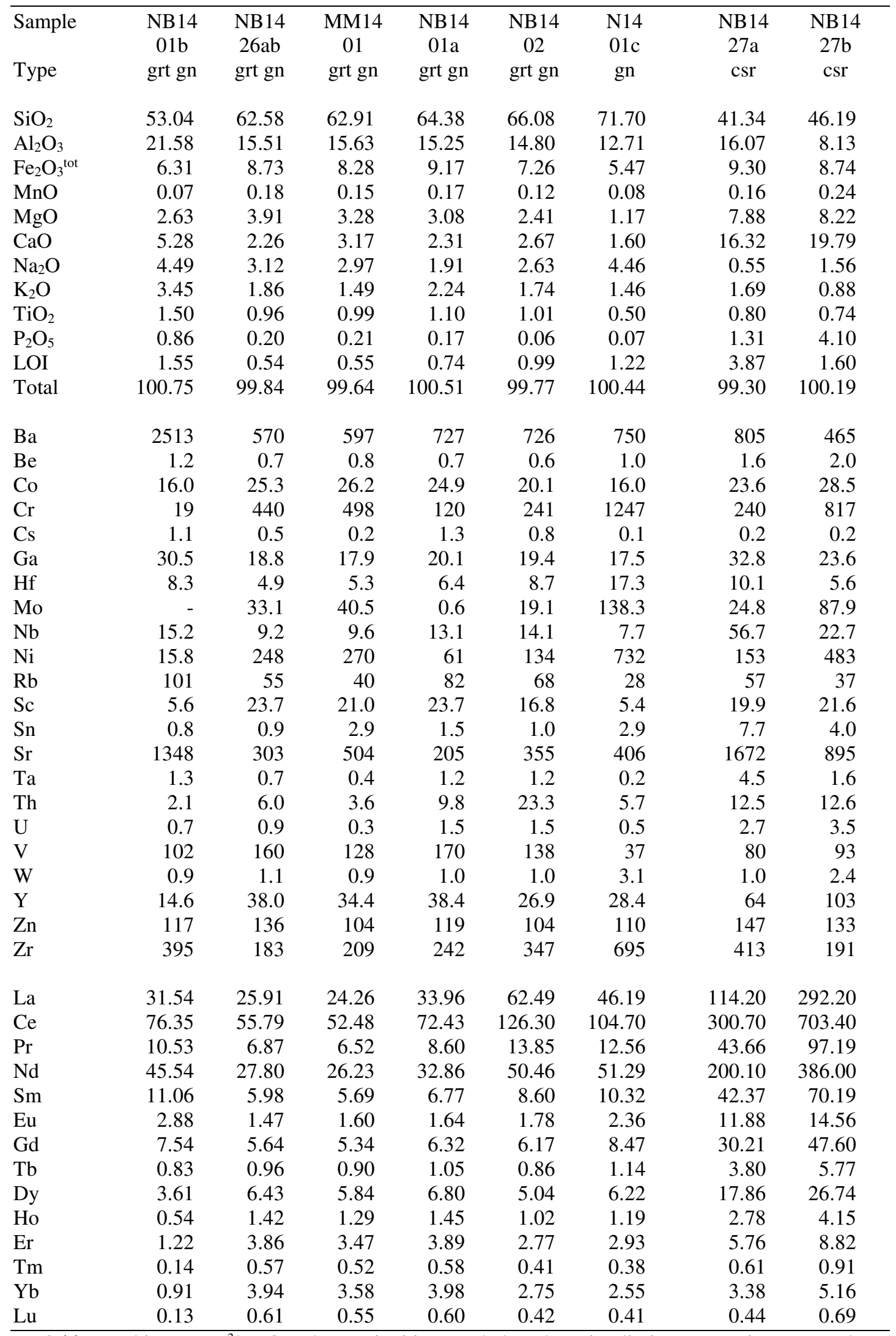

$\mathrm{Fe}_{2} \mathrm{O}_{3}{ }^{\text {tot }}=$ total iron as $\mathrm{Fe}^{3+} ;$ LOI $=$ lost on ignition; - = below detection limit; gn = gneiss; csr = calcsilicate rock; grt = garnet. 
Table 12. Major (wt.\%) and trace element (ppm) composition of intermediate to felsic orthogneiss from the Mbé - Sassa-Mbersi area.

\begin{tabular}{|c|c|c|c|c|c|c|c|c|c|}
\hline Sample & $\begin{array}{l}\text { N14 } \\
01 b\end{array}$ & $\begin{array}{c}\text { K14 } \\
01\end{array}$ & $\begin{array}{c}\text { NB14 } \\
03 b\end{array}$ & $\begin{array}{c}\mathrm{MM} 14 \\
05\end{array}$ & $\begin{array}{c}\text { NB14 } \\
10 \mathrm{a}\end{array}$ & $\begin{array}{c}\text { NB14 } \\
07 b\end{array}$ & $\begin{array}{c}\text { NB14 } \\
03\end{array}$ & $\begin{array}{c}\text { CK09 } \\
01\end{array}$ & $\begin{array}{c}\text { NFA } \\
02\end{array}$ \\
\hline Type & qz-mzd & qz-mzd & qz-mzd & $\mathrm{qz}-\mathrm{mzd}$ & qz-mz & ton & mzgr & syegr & syegr \\
\hline $\mathrm{SiO}_{2}$ & 57.18 & 57.32 & 57.42 & 58.74 & 62.44 & 67.55 & 73.70 & 74.82 & 76.35 \\
\hline $\mathrm{Al}_{2} \mathrm{O}_{3}$ & 15.54 & 15.68 & 14.79 & 17.28 & 16.67 & 15.87 & 14.15 & 13.37 & 13.32 \\
\hline $\mathrm{Fe}_{2} \mathrm{O}_{3}{ }^{\text {tot }}$ & 9.22 & 8.49 & 6.43 & 7.45 & 4.87 & 3.89 & 2.20 & 0.51 & 0.63 \\
\hline $\mathrm{MnO}$ & 0.10 & 0.14 & 0.13 & 0.12 & 0.07 & 0.05 & 0.05 & 0.05 & 0.02 \\
\hline $\mathrm{MgO}$ & 2.98 & 4.64 & 3.06 & 3.26 & 2.06 & 1.84 & 0.50 & 0.03 & 0.06 \\
\hline $\mathrm{CaO}$ & 5.71 & 6.69 & 11.52 & 5.60 & 3.17 & 4.27 & 2.13 & 1.01 & 0.66 \\
\hline $\mathrm{Na}_{2} \mathrm{O}$ & 4.12 & 2.99 & 2.46 & 3.87 & 3.89 & 4.40 & 3.48 & 4.06 & 3.90 \\
\hline $\mathrm{K}_{2} \mathrm{O}$ & 1.79 & 1.90 & 2.38 & 1.97 & 3.66 & 1.45 & 3.58 & 4.33 & 4.99 \\
\hline $\mathrm{TiO}_{2}$ & 1.98 & 0.68 & 0.78 & 0.77 & 0.73 & 0.40 & 0.24 & 0.04 & 0.03 \\
\hline $\mathrm{P}_{2} \mathrm{O}_{5}$ & 0.46 & 0.20 & 0.17 & 0.30 & 0.28 & 0.11 & 0.07 & - & - \\
\hline LOI & 0.71 & 0.85 & 1.68 & 1.06 & 2.86 & 0.99 & 0.47 & 0.35 & 0.29 \\
\hline Total & 99.80 & 99.58 & 100.81 & 100.42 & 100.10 & 100.82 & 100.56 & 98.57 & 100.25 \\
\hline $\mathrm{Ba}$ & 645 & 613 & 504 & 658 & 1924 & 620 & 1067 & 24 & 187 \\
\hline $\mathrm{Be}$ & 1.7 & 0.9 & 2.6 & 2.6 & 1.8 & 1.2 & 1.2 & 4.3 & 5.8 \\
\hline $\mathrm{Co}$ & 28.6 & 25.2 & 17.7 & 23.7 & 11.2 & 12.1 & 4.1 & 0.5 & 1.7 \\
\hline $\mathrm{Cr}$ & 345 & 206 & 92 & 399 & 18 & 47 & 154 & 51 & 172 \\
\hline Cs & 1.0 & 1.0 & 0.9 & 2.9 & 0.4 & 0.3 & 0.4 & 4.8 & 5.0 \\
\hline $\mathrm{Ga}$ & 23.7 & 18.3 & 21.4 & 24.6 & 20.0 & 22.6 & 17.3 & 19.3 & 25.1 \\
\hline Hf & 5.7 & 2.7 & 4.7 & 3.5 & 5.2 & 2.8 & 3.3 & 2.6 & 3.8 \\
\hline Mo & 37.2 & 2.9 & 1.8 & 40.6 & - & - & 17.2 & 3.0 & 19.3 \\
\hline $\mathrm{Nb}$ & 15.4 & 4.6 & 11.7 & 6.6 & 5.3 & 3.4 & 4.2 & 15.6 & 9.1 \\
\hline $\mathrm{Ni}$ & 217 & 46 & 43 & 235 & 13.8 & 25 & 92 & 33 & 101 \\
\hline $\mathrm{Rb}$ & 48 & 62 & 83 & 83 & 76 & 45 & 82 & 122 & 311 \\
\hline $\mathrm{Sc}$ & 8.7 & 25.5 & 15.1 & 18.9 & 8.9 & 8.9 & 3.9 & 2.3 & 2.8 \\
\hline Sn & 2.6 & 0.8 & 4.5 & 2.7 & 1.9 & 1.7 & 1.1 & 1.5 & 5.3 \\
\hline $\mathrm{Sr}$ & 689 & 465 & 804 & 705 & 751 & 672 & 366 & 34 & 71 \\
\hline $\mathrm{Ta}$ & 1.2 & 0.3 & 1.1 & 0.4 & 0.3 & 0.2 & 0.3 & 3.7 & 1.1 \\
\hline Th & 5.4 & 4.8 & 11.6 & 4.4 & 1.7 & 3.6 & 8.2 & 7.0 & 18.1 \\
\hline $\mathrm{U}$ & 0.8 & 0.6 & 4.1 & 0.6 & 0.3 & 0.2 & 1.0 & 22.9 & 4.4 \\
\hline $\mathrm{V}$ & 140 & 141 & 118 & 128 & 79.4 & 58 & 15.1 & 0.9 & 2.1 \\
\hline W & 1.1 & 0.4 & 1.7 & 1.2 & - & - & 0.5 & 0.3 & 0.7 \\
\hline Y & 15.3 & 19.1 & 27.7 & 19.0 & 14.4 & 7.2 & 15.8 & 30.6 & 24.4 \\
\hline $\mathrm{Zn}$ & 124 & 100 & 92 & 113 & 71 & 63 & 45 & 22 & 27 \\
\hline $\mathrm{Zr}$ & 233 & 94 & 171 & 135 & 221 & 99 & 103 & 62 & 61 \\
\hline $\mathrm{La}$ & 37.49 & 18.23 & 33.19 & 28.33 & 33.70 & 24.74 & 22.80 & 2.87 & 13.02 \\
\hline $\mathrm{Ce}$ & 82.32 & 39.61 & 73.58 & 58.94 & 67.77 & 47.51 & 44.79 & 6.38 & 27.20 \\
\hline $\operatorname{Pr}$ & 9.91 & 4.92 & 8.68 & 7.19 & 7.74 & 5.20 & 4.98 & 0.85 & 3.26 \\
\hline $\mathrm{Nd}$ & 38.44 & 19.82 & 32.87 & 28.53 & 28.70 & 18.54 & 18.00 & 3.71 & 11.67 \\
\hline $\mathrm{Sm}$ & 7.23 & 4.25 & 6.64 & 5.87 & 5.07 & 3.13 & 3.32 & 1.61 & 3.30 \\
\hline $\mathrm{Eu}$ & 2.03 & 1.13 & 1.40 & 1.53 & 1.49 & 0.84 & 0.86 & 0.35 & 0.22 \\
\hline $\mathrm{Gd}$ & 5.27 & 3.65 & 5.66 & 4.65 & 3.82 & 2.31 & 2.75 & 2.16 & 3.01 \\
\hline $\mathrm{Tb}$ & 0.69 & 0.55 & 0.85 & 0.65 & 0.51 & 0.31 & 0.43 & 0.49 & 0.54 \\
\hline Dy & 3.54 & 3.37 & 5.22 & 3.61 & 2.83 & 1.60 & 2.62 & 3.74 & 3.42 \\
\hline Ho & 0.60 & 0.72 & 1.03 & 0.70 & 0.55 & 0.28 & 0.54 & 0.86 & 0.71 \\
\hline $\mathrm{Er}$ & 1.35 & 1.93 & 2.75 & 1.84 & 1.38 & 0.67 & 1.50 & 2.74 & 1.93 \\
\hline $\mathrm{Tm}$ & 0.16 & 0.28 & 0.39 & 0.26 & 0.20 & 0.09 & 0.23 & 0.49 & 0.30 \\
\hline $\mathrm{Yb}$ & 0.90 & 1.98 & 2.60 & 1.79 & 1.22 & 0.55 & 1.59 & 3.70 & 2.15 \\
\hline $\mathrm{Lu}$ & 0.13 & 0.30 & 0.39 & 0.27 & 0.19 & 0.08 & 0.25 & 0.61 & 0.33 \\
\hline
\end{tabular}

qz-mzd = quartz monzodiorite; qz-mz = quartz monzonite; ton = tonalite; mzgr = monzogranite; syegr = syenogranite. 
Table 14. Major and trace element compositions of plutonic rocks from the Mbé - Sassa-Mbersi area.

\begin{tabular}{|c|c|c|c|c|c|c|c|c|c|}
\hline Sample & $\begin{array}{c}\text { SM13 } \\
\text { 3b } \\
\text { me }\end{array}$ & $\begin{array}{c}\text { SM13 } \\
\text { 1a } \\
\text { me }\end{array}$ & $\begin{array}{c}\text { NB14 } \\
12 \\
\text { me }\end{array}$ & $\begin{array}{c}\text { SM13 } \\
\text { 3c } \\
\text { me }\end{array}$ & $\begin{array}{c}\text { L14 } \\
03 \\
\text { ton }\end{array}$ & $\begin{array}{c}\text { NG14 } \\
02 \\
\text { ton }\end{array}$ & $\begin{array}{c}\mathrm{NB} 14 \\
08 \mathrm{a} \\
\text { trond }\end{array}$ & $\begin{array}{c}\text { CK13 } \\
6 c \\
\text { hb-gr }\end{array}$ & $\begin{array}{c}\text { NB14 } \\
20 \\
\text { hb-gr }\end{array}$ \\
\hline $\mathrm{SiO}_{2}$ & 49.14 & 52.49 & 54.16 & 65.63 & 60.71 & 66.22 & 74.05 & 56.70 & 57.21 \\
\hline $\mathrm{Al}_{2} \mathrm{O}_{3}$ & 15.24 & 18.62 & 16.56 & 14.96 & 16.26 & 16.19 & 14.66 & 15.72 & 14.55 \\
\hline $\mathrm{Fe}_{2} \mathrm{O}_{3}{ }^{\text {tot }}$ & 11.12 & 8.04 & 7.57 & 4.26 & 7.36 & 3.48 & 1.53 & 7.21 & 6.70 \\
\hline FeOtot & 10.01 & 7.23 & 6.81 & 3.83 & 6.62 & 3.13 & 1.38 & 6.49 & 6.03 \\
\hline $\mathrm{MnO}$ & 0.17 & 0.13 & 0.11 & 0.06 & 0.13 & 0.06 & 0.03 & 0.11 & 0.14 \\
\hline $\mathrm{MgO}$ & 6.19 & 2.87 & 4.61 & 1.55 & 3.16 & 1.72 & 0.60 & 4.96 & 2.89 \\
\hline $\mathrm{CaO}$ & 8.90 & 5.62 & 6.38 & 3.14 & 4.68 & 4.27 & 1.97 & 6.23 & 11.04 \\
\hline $\mathrm{Na}_{2} \mathrm{O}$ & 3.00 & 4.32 & 3.93 & 3.51 & 3.21 & 4.55 & 5.04 & 3.77 & 2.19 \\
\hline $\mathrm{K}_{2} \mathrm{O}$ & 1.94 & 3.87 & 2.03 & 4.20 & 1.29 & 1.84 & 1.76 & 2.14 & 3.16 \\
\hline $\mathrm{TiO}_{2}$ & 1.83 & 1.00 & 1.11 & 0.65 & 0.68 & 0.46 & 0.18 & 1.01 & 0.73 \\
\hline $\mathrm{P}_{2} \mathrm{O}_{5}$ & 0.51 & 0.64 & 0.43 & 0.27 & 0.24 & 0.13 & 0.05 & 0.39 & 0.15 \\
\hline LOI & 1.17 & 1.05 & 2.38 & 0.72 & 2.01 & 0.57 & 0.99 & 0.93 & 1.27 \\
\hline Total & 99.21 & 98.64 & 99.26 & 98.94 & 99.73 & 99.49 & 100.84 & 99.18 & 100.02 \\
\hline $\mathrm{Ba}$ & 1624 & 2520 & 1276 & 1633 & 572 & 413 & 931 & 1103 & 620 \\
\hline $\mathrm{Be}$ & 1.4 & 2.2 & 1.1 & 2.4 & 1.8 & 1.0 & 0.6 & 2.0 & 2.4 \\
\hline $\mathrm{Co}$ & 34.0 & 14.9 & 26.8 & 9.9 & 20.9 & 9.6 & 3.6 & 25.7 & 21.9 \\
\hline $\mathrm{Cr}$ & 83 & 53 & 104 & 96 & 355 & 18 & 17 & 215 & 411 \\
\hline Cs & 1.4 & 2.0 & 0.3 & 1.9 & 1.5 & 0.6 & 0.2 & 1.8 & 1.1 \\
\hline $\mathrm{Ga}$ & 22.0 & 25.2 & 22.7 & 21.8 & 21.9 & 18.5 & 17.1 & 21.1 & 20.5 \\
\hline Hf & 6.0 & 9.0 & 2.2 & 5.7 & 5.0 & 3.7 & 1.9 & 4.5 & 4.7 \\
\hline Mo & 1.5 & 1.0 & ld & 5.6 & 31.5 & 0.8 & ld & 3.1 & 39.0 \\
\hline $\mathrm{Nb}$ & 14.8 & 16.0 & 5.7 & 12.3 & 7.0 & 2.4 & 1.4 & 8.4 & 12.3 \\
\hline $\mathrm{Ni}$ & 18.2 & 17.0 & 52.7 & 47.3 & 193.6 & 13.4 & 7.5 & 104.9 & 239.6 \\
\hline $\mathrm{Rb}$ & 61 & 127 & 37 & 114 & 64 & 38 & 28 & 52 & 116 \\
\hline $\mathrm{Sc}$ & 34.2 & 12.1 & 16.9 & 7.8 & 17.5 & 6.6 & 3.3 & 17.3 & 16.2 \\
\hline Sn & 2.4 & 2.8 & 1.3 & 4.3 & 2.2 & 0.7 & 0.7 & 1.9 & 5.0 \\
\hline $\mathrm{Sr}$ & 1013 & 1541 & 1039 & 696 & 575 & 525 & 644 & 918 & 884 \\
\hline $\mathrm{Ta}$ & 1.1 & 1.2 & 0.4 & 1.2 & 0.4 & 0.2 & 0.0 & 0.6 & 1.0 \\
\hline $\mathrm{Th}$ & 6.3 & 15.8 & 1.2 & 21.1 & 11.1 & 3.2 & 0.2 & 1.4 & 13.1 \\
\hline $\mathrm{U}$ & 1.4 & 2.2 & 0.2 & 3.0 & 1.7 & 0.8 & 0.3 & 2.5 & 3.4 \\
\hline V & 280.0 & 104.7 & 155.4 & 66.6 & 103.8 & 54.9 & 16.2 & 147.0 & 115.1 \\
\hline W & 0.3 & 0.3 & 0.4 & 0.5 & 0.9 & ld & ld & 0.4 & 2.6 \\
\hline $\mathrm{Y}$ & 36.7 & 31.3 & 16.5 & 18.7 & 19.3 & 8.4 & 3.6 & 19.4 & 30.3 \\
\hline $\mathrm{Zn}$ & 116 & 119 & 98 & 57 & 114 & 56 & 32 & 96 & 99 \\
\hline $\mathrm{Zr}$ & 240 & 386 & 75 & 215 & 190 & 128 & 59 & 184 & 158 \\
\hline $\mathrm{La}$ & 42.10 & 94.11 & 32.54 & 60.76 & 40.08 & 9.95 & 6.54 & 31.06 & 33.31 \\
\hline $\mathrm{Ce}$ & 99.81 & 178.70 & 67.39 & 112.60 & 81.95 & 22.59 & 12.41 & 67.47 & 69.25 \\
\hline $\operatorname{Pr}$ & 12.85 & 20.12 & 8.21 & 12.39 & 9.50 & 3.21 & 1.42 & 8.39 & 8.03 \\
\hline $\mathrm{Nd}$ & 54.35 & 73.82 & 32.57 & 43.74 & 35.69 & 13.48 & 5.31 & 34.40 & 30.30 \\
\hline $\mathrm{Sm}$ & 11.12 & 12.92 & 6.15 & 7.63 & 6.40 & 2.75 & 0.97 & 6.52 & 6.11 \\
\hline $\mathrm{Eu}$ & 2.91 & 3.33 & 1.98 & 1.58 & 1.45 & 0.83 & 0.45 & 1.74 & 1.29 \\
\hline $\mathrm{Gd}$ & 8.65 & 9.26 & 4.48 & 5.29 & 4.79 & 2.10 & 0.79 & 4.86 & 5.26 \\
\hline $\mathrm{Tb}$ & 1.25 & 1.22 & 0.60 & 0.70 & 0.65 & 0.29 & 0.12 & 0.66 & 0.83 \\
\hline Dy & 6.81 & 6.22 & 3.31 & 3.63 & 3.71 & 1.59 & 0.67 & 3.64 & 5.23 \\
\hline Ho & 1.29 & 1.09 & 0.64 & 0.63 & 0.74 & 0.31 & 0.13 & 0.67 & 1.12 \\
\hline $\mathrm{Er}$ & 3.48 & 2.94 & 1.61 & 1.71 & 1.95 & 0.78 & 0.34 & 1.80 & 3.11 \\
\hline $\mathrm{Tm}$ & 0.51 & 0.41 & 0.22 & 0.24 & 0.27 & 0.11 & 0.05 & 0.26 & 0.47 \\
\hline $\mathrm{Yb}$ & 3.37 & 2.68 & 1.41 & 1.59 & 1.86 & 0.77 & 0.32 & 1.75 & 3.19 \\
\hline $\mathrm{Lu}$ & 0.50 & 0.41 & 0.21 & 0.23 & 0.28 & 0.13 & 0.05 & 0.27 & 0.51 \\
\hline
\end{tabular}


Table 14. (Continued)

\begin{tabular}{|c|c|c|c|c|c|c|}
\hline Sample & $\begin{array}{c}\text { M13 } \\
1 \mathrm{c}\end{array}$ & $\begin{array}{c}\text { NB14 } \\
04\end{array}$ & $\begin{array}{c}\text { M13 } \\
3 c\end{array}$ & $\begin{array}{c}\mathrm{L} 14 \\
01\end{array}$ & $\begin{array}{c}\text { NB14 } \\
40\end{array}$ & $\begin{array}{c}\text { MM14 } \\
07\end{array}$ \\
\hline Type & hb-gr & hb-gr & bt gr & bt gr & bt gr & bt gr \\
\hline $\mathrm{SiO}_{2}$ & 59.45 & 65.81 & 68.84 & 68.88 & 72.22 & 72.44 \\
\hline $\mathrm{Al}_{2} \mathrm{O}_{3}$ & 16.75 & 14.38 & 14.02 & 15.17 & 13.83 & 14.18 \\
\hline $\mathrm{Fe}_{2} \mathrm{O}_{3}{ }^{\text {tot }}$ & 5.83 & 4.81 & 3.53 & 3.03 & 1.87 & 1.76 \\
\hline FeOtot & 5.25 & 4.33 & 3.18 & 2.73 & 1.68 & 1.58 \\
\hline $\mathrm{MnO}$ & 0.09 & 0.09 & 0.04 & 0.03 & 0.03 & 0.03 \\
\hline $\mathrm{MgO}$ & 2.50 & 2.06 & 0.66 & 0.73 & 0.42 & 0.37 \\
\hline $\mathrm{CaO}$ & 4.34 & 3.15 & 1.66 & 2.11 & 1.36 & 1.36 \\
\hline $\mathrm{Na}_{2} \mathrm{O}$ & 4.32 & 2.86 & 2.79 & 3.33 & 3.10 & 3.20 \\
\hline $\mathrm{K}_{2} \mathrm{O}$ & 3.51 & 3.77 & 6.05 & 5.56 & 5.28 & 5.52 \\
\hline $\mathrm{TiO}_{2}$ & 0.93 & 0.61 & 0.63 & 0.52 & 0.27 & 0.24 \\
\hline $\mathrm{P}_{2} \mathrm{O}_{5}$ & 0.42 & 0.16 & 0.22 & 0.17 & 0.07 & 0.08 \\
\hline $\mathrm{PF}$ & 0.88 & 2.36 & 0.48 & 1.16 & 1.09 & 0.37 \\
\hline Total & 99.02 & 100.07 & 98.92 & 100.69 & 99.53 & 99.54 \\
\hline $\mathrm{Ba}$ & 1463 & 1132 & 1143 & 1519 & 1101 & 976 \\
\hline $\mathrm{Be}$ & 3.3 & 1.3 & 1.7 & 2.0 & 1.4 & 1.5 \\
\hline $\mathrm{Co}$ & 14.4 & 14.5 & 4.5 & 8.1 & 4.0 & 3.1 \\
\hline $\mathrm{Cr}$ & 51 & 77 & 58 & 507 & 149 & 115 \\
\hline Cs & 3.5 & 0.4 & 0.7 & 0.9 & 0.5 & 0.5 \\
\hline $\mathrm{Ga}$ & 24.6 & 19.6 & 25.8 & 22.2 & 18.2 & 19.7 \\
\hline Hf & 8.1 & 5.0 & 14.4 & 10.9 & 6.1 & 4.7 \\
\hline Mo & 2.8 & 0.6 & 3.2 & 55.5 & 17.4 & 16.5 \\
\hline $\mathrm{Nb}$ & 16.4 & 10.7 & 25.3 & 10.3 & 9.0 & 11.8 \\
\hline $\mathrm{Ni}$ & 26.7 & 35.0 & 27.5 & 290.0 & 86.2 & 68.2 \\
\hline $\mathrm{Rb}$ & 110 & 122 & 228 & 182 & 185 & 199 \\
\hline $\mathrm{Sc}$ & 9.6 & 10.0 & 4.0 & 3.7 & 3.1 & 3.0 \\
\hline Sn & 2.9 & 1.9 & 6.5 & 3.6 & 2.1 & 1.4 \\
\hline $\mathrm{Sr}$ & 989 & 408 & 273 & 365 & 226 & 241 \\
\hline $\mathrm{Ta}$ & 2.1 & 0.9 & 1.3 & 0.4 & 0.5 & 0.7 \\
\hline Th & 11.6 & 12.1 & 82.7 & 41.3 & 31.0 & 37.5 \\
\hline $\mathrm{U}$ & 4.0 & 1.3 & 2.2 & 2.7 & 1.3 & 2.2 \\
\hline V & 94.6 & 64.8 & 24.4 & 28.8 & 18.0 & 14.0 \\
\hline W & 0.7 & 0.4 & ld & 1.7 & 0.7 & 0.5 \\
\hline Y & 29.4 & 13.6 & 21.3 & 10.7 & 11.9 & 11.5 \\
\hline $\mathrm{Zn}$ & 99 & 95 & 105 & 57 & 49 & 47 \\
\hline $\mathrm{Zr}$ & 339 & 177 & 592 & 437 & 223 & 151 \\
\hline $\mathrm{La}$ & 48.10 & 40.90 & 193.60 & 137.10 & 62.55 & 86.11 \\
\hline $\mathrm{Ce}$ & 115.50 & 83.60 & 383.40 & 259.60 & 127.20 & 157.50 \\
\hline $\operatorname{Pr}$ & 14.93 & 9.43 & 42.29 & 26.03 & 13.24 & 16.24 \\
\hline $\mathrm{Nd}$ & 59.15 & 33.57 & 143.10 & 82.94 & 43.91 & 53.35 \\
\hline $\mathrm{Sm}$ & 10.95 & 5.75 & 21.08 & 10.64 & 6.79 & 8.08 \\
\hline $\mathrm{Eu}$ & 2.42 & 1.19 & 1.88 & 1.36 & 0.85 & 0.92 \\
\hline $\mathrm{Gd}$ & 7.64 & 4.11 & 11.99 & 6.09 & 4.32 & 4.83 \\
\hline $\mathrm{Tb}$ & 1.06 & 0.54 & 1.34 & 0.63 & 0.52 & 0.58 \\
\hline Dy & 5.56 & 2.85 & 5.61 & 2.72 & 2.60 & 2.69 \\
\hline Ho & 1.01 & 0.53 & 0.76 & 0.42 & 0.45 & 0.44 \\
\hline $\mathrm{Er}$ & 2.65 & 1.30 & 1.98 & 1.10 & 1.15 & 1.10 \\
\hline $\mathrm{Tm}$ & 0.40 & 0.17 & 0.23 & 0.14 & 0.15 & 0.14 \\
\hline $\mathrm{Yb}$ & 2.53 & 1.11 & 1.37 & 0.93 & 1.01 & 0.93 \\
\hline $\mathrm{Lu}$ & 0.37 & 0.17 & 0.19 & 0.16 & 0.16 & 0.14 \\
\hline
\end{tabular}

$\mathrm{me}=$ microgranular enclave; ton $=$ tonalite $;$ trond $=$ trondhjemite $; \mathrm{hb} \mathrm{gr}=$ hornblende-biotite granite; bt gr = biotite granite; $\operatorname{lgr}=$ leucogranite. 

The Central Cameroon Domain exposes the partially molten root of the Pan-African Central African Orogenic Belt

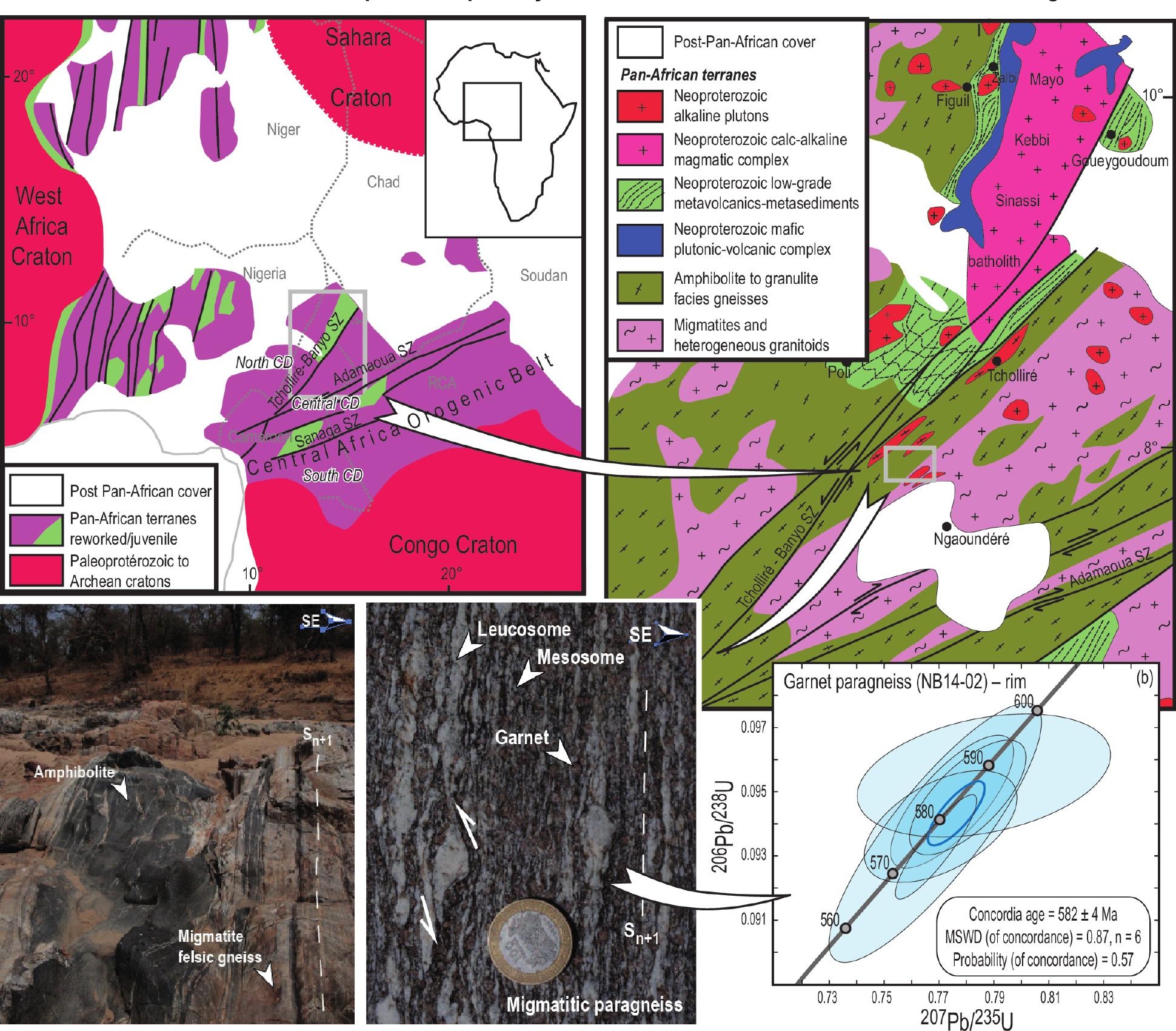

